Risk Management of Foodborne

Zoonotic Bacteria from Farm to Table in the Nordic Countries 

Risk Management of Foodborne

Zoonotic Bacteria from Farm to Table in the Nordic Countries

TemaNord 2004:525 


\title{
Risk Management of Foodborne Zoonotic Bacteria from Farm to Table in the Nordic Countries
}

\author{
TemaNord 2004:525
}

(C) Nordic Council of Ministers, Copenhagen 2004

ISBN 92-893-1012-X

ISSN 0908-6692

Print: Ekspressen Tryk \& Kopicenter

Copies: 280

Printed on paper approved by the Nordic Environmental Labelling.

This publication may be purchased from any of the sales agents listed on the last page.

Nordic Council of Ministers

Store Strandstræde 18

DK-1255 Copenhagen K

Phone (+45) 33960200

Fax (+45) 33960202

\author{
Nordic Council
}

Store Strandstræde 18

DK-1255 Copenhagen K

Phone (+45) 33960400

Fax $\quad(+45) 33111870$

www.norden.org

\begin{abstract}
The Nordic Food Policy Co-operation
The Nordic Committee of Senior Officials for Food Issues is concerned with basic Food Policy issues relating to food and nutrition, food toxicology and food microbiology, risk evaluation, food control and food legislation. The co-operation aims at protection of the health of the consumer, common utilisation of professional and administrative resources and at Nordic and international developments in this field.
\end{abstract}

\section{The Nordic Council of Ministers}

was established in 1971. It submits proposals on co-operation between the governments of the five Nordic countries to the Nordic Council, implements the Council's recommendations and reports on results, while directing the work carried out in the targeted areas. The Prime Ministers of the five Nordic countries assume overall responsibility for the co-operation measures, which are co-ordinated by the ministers for co-operation and the Nordic Co-operation committee. The composition of the Council of Ministers varies, depending on the nature of the issue to be treated.

\section{The Nordic Council}

was formed in 1952 to promote co-operation between the parliaments and governments of Denmark, Iceland, Norway and Sweden. Finland joined in 1955. At the sessions held by the Council, representatives from the Faroe Islands and Greenland form part of the Danish delegation, while Åland is represented on the Finnish delegation. The Council consists of 87 elected members - all of whom are members of parliament. The Nordic Council takes initiatives, acts in a consultative capacity and monitors co-operation measures. The Council operates via its institutions: the Plenary Assembly, the Presidium and standing committees. 


\section{Contents}

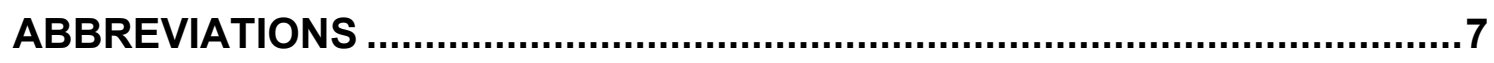

PREFACE

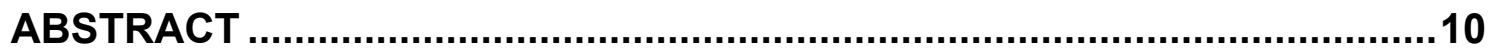

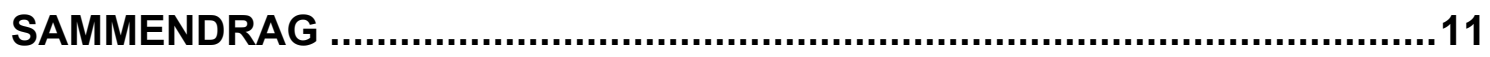

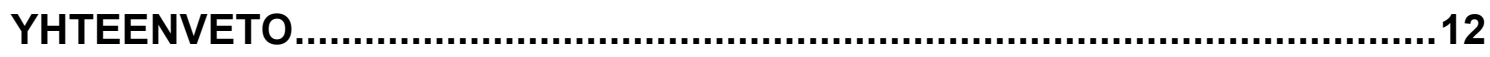

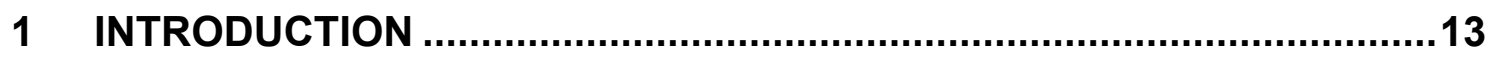

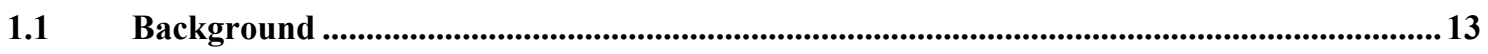

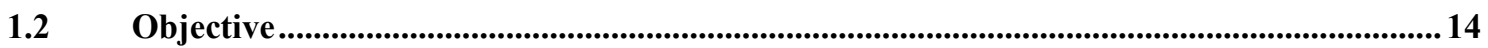

2 RISK MANAGEMENT FROM FARM TO TABLE ..................................15

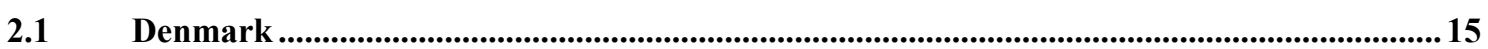

2.1.1 Overall National Policy ..................................................................................................... 15

2.1.2 Food Safety Legislation..................................................................................................... 17

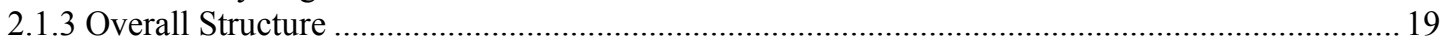

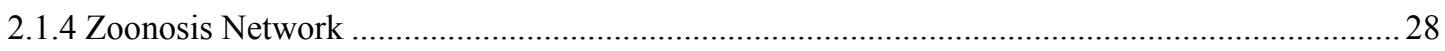

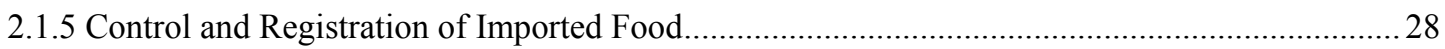

2.1.6 Monitoring/Surveillance of Zoonotic Pathogens ....................................................................... 29

2.1.7 Monitoring/Surveillance of Anti-microbial Resistance ................................................................ 31

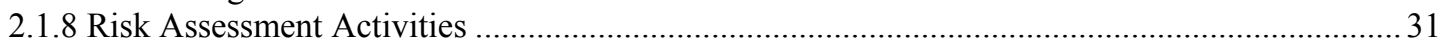

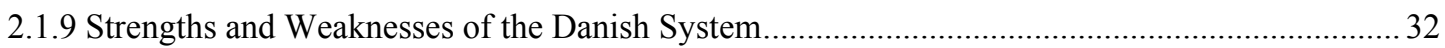

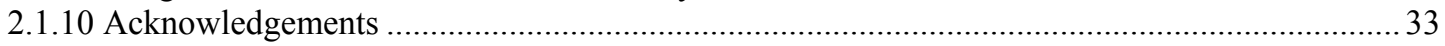

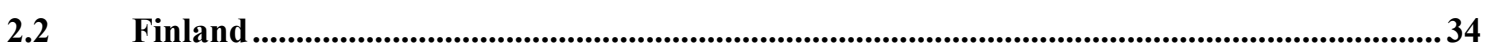

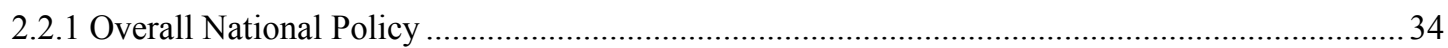

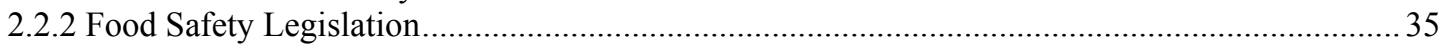

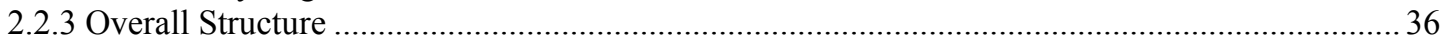

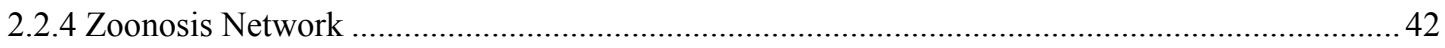

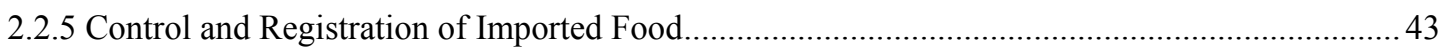

2.2.6 Monitoring/Surveillance of Zoonotic Pathogens ...........................................................................4 44

2.2.7 Monitoring/Surveillance of Anti-microbial Resistance ...............................................................46

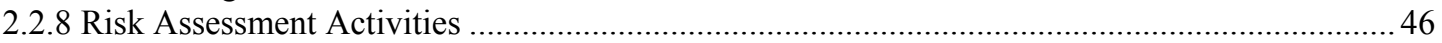

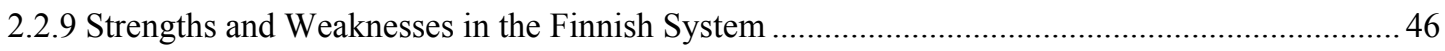

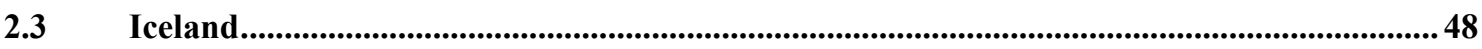

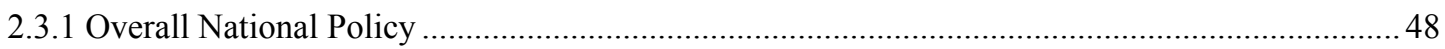

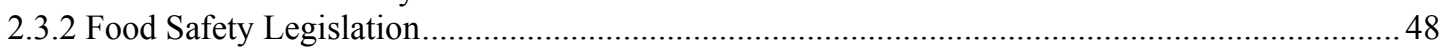

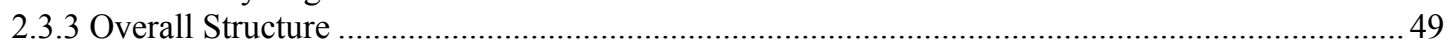




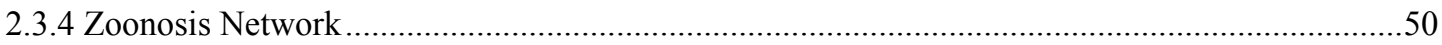

2.3.5 Control and Registration of Imported Food .......................................................................5

2.3.6 Monitoring/Surveillance of Zoonotic Pathogens ...................................................................51

2.3.7 Monitoring/Surveillance of Anti-microbial Resistance .......................................................51

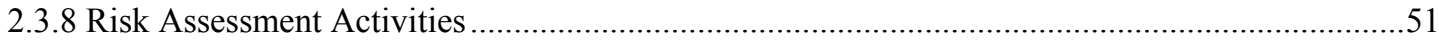

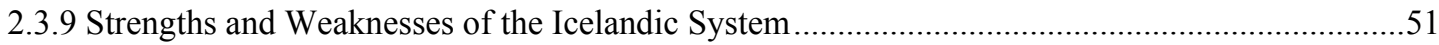

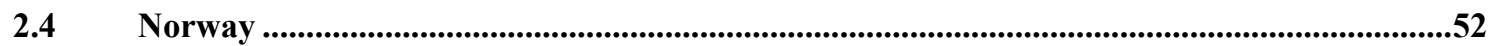

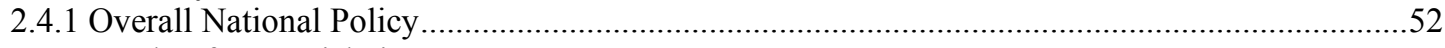

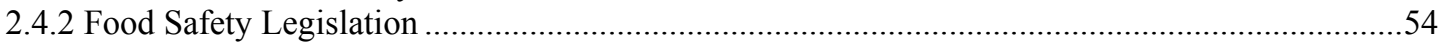

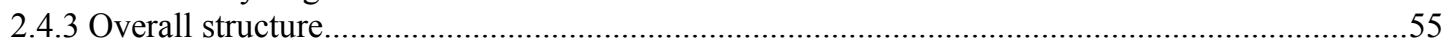

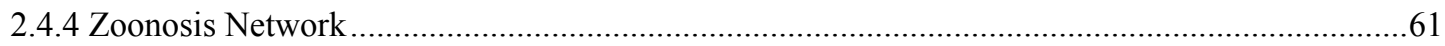

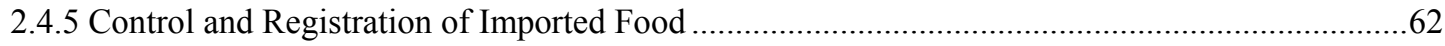

2.4.6 Monitoring/Surveillance of Zoonotic pathogens............................................................63

2.4.7 Surveillance of Antimicrobial Resistance ........................................................................68

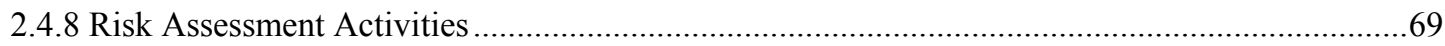

2.4.9 Strengths and Weaknesses of the Norwegian System......................................................69

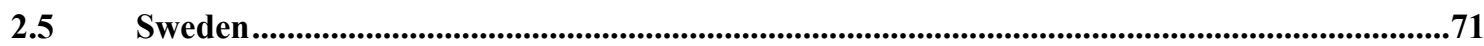

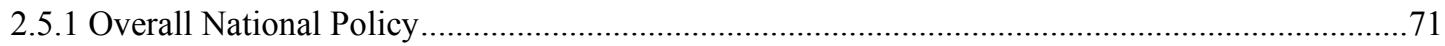

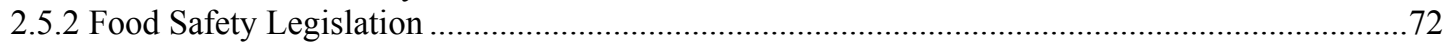

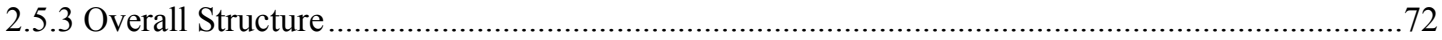

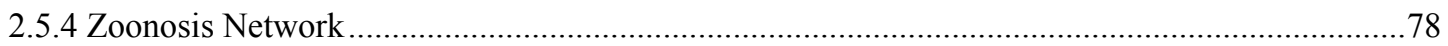

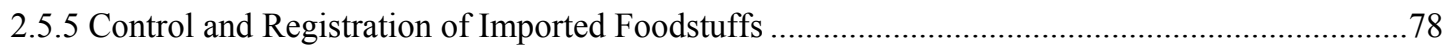

2.5.6 Monitoring/Surveillance of Zoonotic Pathogens .................................................................79

2.5.7 Monitoring/Surveillance of Anti-microbial Resistance ......................................................82

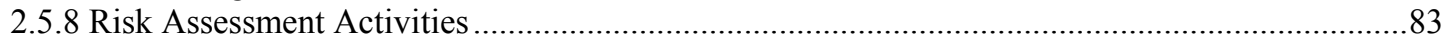

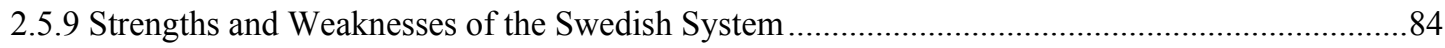

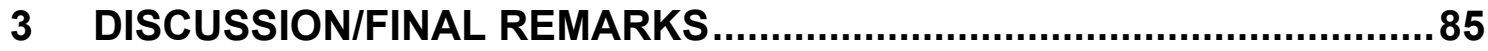

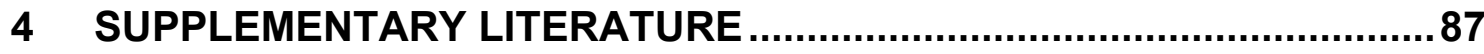




\section{Abbreviations}

BIP

DAAC

DDB

DG-SANCO

DIFRES

DLMB

DPD

DP

DVIV

DVL

DZC

DVFA

EEA

EELA

EFA

EHEC

EPA

FD

FID

FSO

HACCP

KNT

LD

LT

MAF

NBHW

NFA

NFA

NNM

NPHI
Border Inspection Post

The Danish Agricultural Advisory Centre

Danish Dairy Board

EU Health \& Consumer Protection Directorate-General

Danish Institute for Fisheries Research

The Danish Livestock and Meat Board

Danish Plant Directorate

Danish Poultry (Det Danske Fjerkræråd)

Danish Veterinary Institute for Virus Research

Danish Veterinary Laboratory

Danish Zoonosis Centre

Danish Veterinary and Food Administration

European Economic Area

National Veterinary and Food Research Institute (Finland)

Environmental and Food Agency (Iceland)

Enterohemorrhagic E. coli (E. coli O157, and more)

Swedish Environmental Protection Agency

Directorate of Fisheries (Norway)

Ministry of Fisheries (Norway)

Food Safety Objectives

Hazard Analysis Critical Control Point

Municipal Food Control Authorities (Norway)

Ministry of Agriculture (Norway)

Norwegian Agriculture Inspection Service

Ministry of Agriculture and Forestry (Finland)

National Board of Health and Welfare (Sweden)

National Food Administration (Finland)

National Food Administration (Sweden)

Nordic Working Group on Food Microbiology and Risk Assessment

National Public Health Institute (Finland) 
NZ

PPIC

SAHS

SALA

SBA

SDT

SHD

SIIDC

SNT

SSI

STM

TVC

VI
Norwegian Zoonosis Centre

Plant production Inspection Centre (Finland)

Swedish Animal Health Service

Swedish Association of Local Authorities

Swedish Board of Agriculture

Norwegian Animal Health Authority

Ministry of Health and Social Affairs (Norway)

Swedish Institute for Infectious Disease Control

Norwegian Food Control Authority

State Serum Institute (Denmark)

Ministry of Social Affairs and Health, Finland

Total Viable Counts

National Veterinary Institute (Norway) 


\section{Preface}

The present report was prepared by a Nordic working group for the Nordic Council of Ministers. The report is one of two parallel Nordic reports, the first concerning risk management of food borne zoonotic bacteria from farm to table in the Nordic countries, and the second concerning microbiological databases in the Nordic countries. The report covering the project on microbiological databases also includes as an annex the outcome of a project concerning Salmonella data. To enhance the readability, the project concerning risk management is covered separately in the present report.

The following people from a Nordic working group have contributed to this report:

\begin{tabular}{|lll|}
\hline Nina Aas & Norwegian Food Control Authority & Norway \\
Jens Kirk Andersen & Danish Veterinary and Food Administration & Denmark \\
Franklin Georgsson & Environmental and Food Agency of Iceland & Iceland \\
Hilde Kruse & Norwegian Zoonosis Centre & Norway \\
Riitta Maijala & National Veterinary and Food Research Institute & Finland \\
Niels Ladefoged Nielsen & Danish Veterinary and Food Administration & Denmark \\
Erland Pääjärvi & National Food Administration & Sweden \\
Charlotte Schöller & Danish Veterinary and Food Administration & Denmark \\
Asmundur Thorkelsson & Environmental and Food Agency of Iceland & Iceland \\
Ivar Vågsholm & Swedish Zoonosis Centre & Sweden \\
Helene Wahlström & Swedish Zoonosis Centre & Sweden \\
\hline
\end{tabular}

The report was edited by Charlotte Schöller and Jens Kirk Andersen.

The Nordic Working group on Food Microbiology and Risk Assessment (NNM) under the Nordic Committee of Senior Officials for Food Issues (EK-LIVS) approved the report in January, 2001. 


\section{Abstract}

The present report has been prepared for the Nordic Council of Ministers by a Nordic working group. The report is one of two parallel reports, the first concerning risk management of zoonotic bacteria from farm to table in the Nordic countries, and the second concerning microbiological databases in the Nordic countries. The Nordic countries have a tradition of addressing foodborne health hazards with a perspective encompassing all steps from farm to table. This policy enables control measures to be carried out as close to the source as possible. Thus, both Nordic agriculture and the Nordic control systems possess a structure making an efficient preventive effort against many food borne zoonotic agents possible already in the primary production.

This report presents an overview of the existing risk management systems for food borne zoonotic pathogens within each Nordic country. The report contains contributions from each of the Nordic countries. Each contribution presents the overall food safety policy in that specific country, and outlines the structure and organisation of the food control systems, the food safety legislation, the control and registration of foodstuffs, and monitoring/surveillance programmes. Risk assessment activities concerning food borne zoonotic agents are briefly described. At the end of each section the strengths and weaknesses of the systems in the specific countries are listed.

Finally, the report includes a discussion that summarises an exchange of views and experiences concerning risk management for food safety based on the farm to table philosophy. Here, principles for risk management, which have been outlined in a proposed draft paper for the Codex Committee of Food Hygiene on the principles and guidelines for the conduct of microbiological risk management, are discussed. The working group agreed that the proposed guidelines should be followed to the largest possible extent. Each country has mentioned the strengths and weaknesses of each specific country's risk management systems for food borne zoonotic bacteria. The importance of the functional separation of the risk assessment and risk management processes is emphasised. One of the strengths of the Nordic risk management systems is that they encompass the whole farm to table continuum. The good collaboration between the Nordic countries is pointed out as an advantage 


\section{Sammendrag}

Nærværende rapport er udarbejdet til Nordisk Ministerråd af en nordisk arbejdsgruppe. Rapporten er en af to parallelle rapporter, omhandlende dels risikohåndtering fra jord til bord, dels mikrobiologiske databaser i Norden.

De nordiske lande har en tradition for at anskue fødevarebårne helbredsrisici i et perspektiv, som omfatter alle niveauer fra jord til bord. Denne politik muliggør at kontrolforanstaltninger udføres så tæt på kilden som muligt. Således har både nordisk landbrug og de nordiske kontrolsystemer en struktur, som gør en effektiv indsats overfor mange fødevarebårne sygdomme mulige allerede i primærproduktionen.

Denne rapport omhandler en gennemgang af de eksisterende risikohåndteringssystemer for fødevarebårne zoonotiske bakterier i hvert enkelt af de nordisk lande. Rapporten er opbygget af bidrag fra hvert land, og hvert bidrag søger at gennemgå den overordnede struktur og organisering af kontrolsystemerne, fødevarelovgivningen, og beskriver ligeledes overvågningsprogram og kontrol og registrering af importerede fødevarer. Ligeledes er arbejde, som er udført indenfor mikrobiologisk risikovurdering, kort beskrevet. I slutningen af hver sektion er styrker og svagheder ved hvert lands fødevarekontrolsystem kort opridsede.

I rapportens diskussion opsummeres en udveksling af synspunkter og erfaringer vedrørende risikohåndtering indenfor fødevaresikkerhed, baseret på jord til bord filosofien. I dette afsnit diskuteres de principper for risikohåndtering, som er opridsede i den foreslåede Codex papir, udarbejdet af Frankrig, om principper og retningsliner for udførelsen af mikrobiologisk risikohåndtering. Gruppen var enig om, at disse retningslinier burde følges i videst mulige grad.

Hvert land har nævnt styrker og svagheder ved deres respektive risikohåndteringssystemer for levnedsmiddelbårne zoonotiske bakterier. Vigtigheden af den funktionelle adskillelse af risikovurderingen og risikoanalysen blev understreget. En af fordelene ved de nordiske risikohåndteringssystemer er, at de omhandler hele kæden fra jord til bord, og at der er et godt samarbejde mellem de nordiske lande. 


\section{Yhteenveto}

Tämän raportin on tuottanut Pohjoismaisen ministerineuvoston työryhmä. Raportti kuuluu kahden raportin kokonaisuuteen, joista tämä ensimmäinen raportti käsittelee zoonoottisten bakteerien riskinhallintaa pellolta pöytään Pohjoismaissa ja toinen pohjoismaisia mikrobiologisia tietokantoja. Pohjoismaissa on perinteisesti käsitetty elintarvikevälitteisten terveysvaarojen hallintaan kuuluvaksi mukaan kaikki vaihteet pellolta pöytään asti. Tämä politiikan avulla voidaan riskinhallintatoimet kohdistaa niin lähelle tartuntalähdettä kuin mahdollista. Siksi sekä pohjoismainen maatalous että pohjoismainen valvontasysteemi omaavat rakenteen, jonka avulla monia elintarvikevälitteisiä zoonoottisia taudinaiheuttajia voidaan ehkäistä jo alkutuotannossa.

Tässä raportissa kuvataan eri Pohjoismaissa käytössä olevat elintarvikevälitteisten zoonoosien riskinhallintajärjestelmät. Jokaisen Pohjoismaan kohdalla esitellään maan yleinen elintarviketurvallisuuspolitiikka, elintarvikevalvonnan rakenne ja organisaatio, elintarvikelainsäädäntö, elintarvikkeiden valvonta ja rekisteröinti sekä seuranta ja valvontaohjelmat. Elintarvikevälitteisiä zoonoottisia taudinaiheuttajia käsittelevä riskinarviointitoiminta kuvataan lyhyesti. Jokaisen maan tekstiosan lopussa on lueteltu järjestelmän vahvuuksia ja heikkouksia.

Raportti sisältää myös yhteenvedon keskustelusta, jossa vaihdettiin mielipiteitä ja kokemuksia pellolta pöytään -periaatteeseen perustuvasta elintarviketurvallisuuden riskinhallinnasta. Tässä osassa käsitellään Codex Alimentariuksen Elintarvikehygieniakomitean ehdotuksen mukaisia riskinhallinnan periaatteita. Työryhmän mielestä ehdotettuja suuntaviivoja tulisi seurata mahdollisimman tarkkaan. Jokainen Pohjoismaa on listannut oman järjestelmänsä vahvuudet ja heikkoudet elintarvikevälitteisten zoonoosien riskinhallinnassa. Raportissa korostetaan riskinarvioinnin ja riskinhallinnan toiminnallista erottamista toisistaan. Eräs pohjoismaisen riskinhallintajärjestelmän vahvuus on, että se käsittää koko tuotantoketjun pellolta pöytään asti. Työryhmä katsoo, että myös Pohjoismaiden välisestä hyvästä yhteistyöstä on etua tässä työssä. 


\section{Introduction}

\subsection{Background}

The Nordic countries have a tradition of looking at food borne health hazards at all levels from farm to table in order for control measures to be carried out as close to the source as possible. In contrast to the situation in many other countries, both Nordic agriculture and the Nordic control systems possess a structure which make an efficient preventive effort against the most important food borne diseases possible already at primary production. Furthermore, Sweden, Norway, Finland, and Denmark have all implemented the Zoonosis Directive (Council Directive 92/117/EEC). (A Nordic review of the possibilities of setting up objectives for food safety based on this situation is desirable)

As a basis for the combat and prevention of pathogenic zoonotic bacteria in foodstuffs it is of great value to have a well documented knowledge of the risk of disease connected to a certain pathogen in a certain food product, and a knowledge of which preventive efforts will result in the greatest effect. In recent year, risk analysis has become an important tool in dealing with public health risks also within the field of microbiological food safety. The fact that risk analysis also is a crucial element in the World Trade Organisation's SPS-agreement, has increased the need for and interest in building up competence in risk analysis.

The risk analysis process, according to Codex Alimentarius, consists of three interlinked elements: Risk assessment, risk management, and risk communication.

Risk assessment is "A scientifically based process consisting of the following steps: i) hazard identification, ii) hazard characterisation, iii) exposure assessment, and iv) risk characterisation."

The risk management process is the "process, distinct from risk assessment, of weighing policy alternatives, in consultation with interested parties, considering risk assessment and other factors relevant for the health protection of consumers and for the promotion of fair trade practices, and, if needed, selecting appropriate prevention and control options". The risk management decisions should be fully and systematically documented and available to all interested parties on request in order to ensure transparency.

In the "Proposed Draft Principles and Guidelines for the Conduct of Microbiological Risk Management" which currently is at step 3 in the Codex Alimentarius process, twelve principles for microbiological risk management are listed:

- "Principle 1: Protection of human health should be the primary consideration in risk management decisions."

- "Principle 2: Risk management should include clear, interactive communication with consumers and other interested parties in all aspects of the process." 
- "Principle 3: Processes and decisions should be transparent and fully documented."

- "Principle 4: Risk Management should ensure the scientific integrity of the risk assessment process by maintaining the functional separation of risk management and risk assessment. In this respect there should be a clear determination of risk assessment policy before risk assessment commences."

- "Principle 5: Risk managers should take into account the uncertainty of the risk estimate when making risk management decisions."

- ["Principle 6: In case where scientific knowledge of the risks is insufficient, risk management decisions may be adopted on an interim basis as part of a precautionary approach to protect public health."]

- "Principle 7: Arriving at a risk management decision should follow a structured process and must include identification of available risk management options and their likely impact on mitigating risk to human health."

- "Principle 8: Risk management decisions should address the whole farm to table continuum, including imported foods."

- "Principle 9: Risk managers should ensure that any control measures that are to be implemented are optimal regarding their feasibility and effectiveness and that they are proportionate to the risks identified."

- "Principle 10: Risk management decisions should be reviewed as new information becomes available.

- "Principle 11: The efficacy of risk management measures has to be periodically assessed with regard to the risk management goals. These measures have to be reviewed if appropriate."

Risk analysis furthermore includes risk communication, which, according to FAO/WHO is: "The interactive exchange of information and opinions throughout the risk analysis process concerning hazards and risks, risk-related factors and risk perceptions, among risk assessors, risk managers, consumers, industry, the academic community, and other interested parties, including the explanation of risk assessment findings and the basis of risk management decisions."

\subsection{Objective}

The objective of this report was:

- to present an overview of the existing risk management systems for food borne zoonotic pathogens within each Nordic country

- to exchange views and experiences concerning risk management for foodborne zoonotic bacteria based on the "Farm to Table" philosophy. 


\section{Risk Management from Farm to Table}

\section{$2.1 \quad$ Denmark}

\subsubsection{Overall National Policy}

During the recent years almost 8000 cases of food related illnesses caused by pathogenic micro-organisms in foodstuffs have been registered annually at the State Serum Institute of Denmark. However, only part of the food-borne illnesses are diagnosed and registered, and the true incidence of illnesses related to food is estimated to be at least ten times larger than the number of registered cases. In the future, the authorities wish to set up food safety objectives, which may encompass the disease incidence in humans, and the acceptable level of a pathogen in foods or even specific microbiological criteria. These food safety objectives represent the authorities' reference points in their work towards the reduction of the level of a certain pathogen.

First, it is possible to carry out the prevention of pathogens in foodstuffs already in the primary production. However, the growth and dispersal of pathogenic bacteria must also be prevented through the successive steps of production, distribution and retail. In connection to this, a continued effort concerning optimisation of the hygiene at the abattoirs is of crucial importance.

The producer bears the responsibility that the foodstuff sold does not pose a risk to human health. Furthermore, all companies producing or distributing food are obliged to develop programs for own check based on the HACCP (Hazard Analysis Critical Control Point) principle. The main preventive effort thus lies in the prevention in the primary production and in the HACCP based surveillance in the successive production, distribution and retailing steps.

Before December 1996, food safety issues were shared between the Ministry of Health and the Ministry of Agriculture and Fisheries. The government's establishment of the Ministry of Food, Agriculture and Fisheries in December 1996 has paved the way for co-ordinated food production, from its origins in the soil or sea until it ends at the consumers' tables. The co-ordinated approach is seen as a clear advantage for consumers, the retail sector, and the processing industry, farmers and fishermen. The Department in the Ministry of Food, Agriculture and Fisheries had 195 employees in 1998.

The objectives of the Ministry of Food, Agriculture and Fisheries is to create a closer link between consumer policy and industrial policy, and thus:

- Ensure that the foodstuffs produced and marketed are healthy and of high quality, and to ensure a high level of consumer information concerning these foodstuffs. 
- Promote those production conditions that provide a sustainable resource use in the agricultural and fishing industries, and which secure the environment, animal welfare and good working conditions.

- Promote a profitable production and sale within the Ministry's industrial purview.

The governmental statement on food policy from January 1998 contains the overall objectives for the government's work on food safety: the government will not compromise the basic food safety, which has to be satisfactory, and will work both nationally and internationally to ensure a high level of protection.

The future policy rests on the three fundamental principles: safety, transparency and credibility. The government wishes to co-ordinate the use of public funds, which in 1998 amounted to an estimated 870 million DKK, between research, legislation and control of food safety.

Due to the need of superior strategies, objectives and periods for a joint effort towards Salmonella and other pathogenic micro-organisms, the Ministry of Food, Agriculture and Fisheries prepared a pathogen strategy in 1998. Thus, the pathogens Salmonella, Campylobacter, Yersinia and E. coli $\mathrm{O} 157$ should have the highest priority. Furthermore, Listeria is to be given high priority.

Furthermore, the government aims at a reduction in the use of anti-microbials and other pharmaceuticals in the veterinary production, and an eventual prohibition of antimicrobials for use as growth promoters.

\section{Risk communication - public information campaigns}

Due to the changes in the traditions for foodstuff production and cooking and due to the fact, that knowledge concerning cooking and hygiene is now only passed down through the generations to a limited extent, the demands on information and communication concerning kitchen hygiene and risks in connection to foodstuffs is increasing.

The third element in risk analysis - the risk communication - is carried out between the parties involved in the risk analysis process. Thus, the risk communication is between researchers, who carry out the risk assessment, and politicians, administrative personnel, consumer representatives and the various producers. New rules and regulations are sent to both the consumer and trade organisations for commenting before they are adopted. The communication with the consumers takes place partly via the consumer organisations, and partly via consumer education in the news media or in periodicals and information pamphlets, on the Internet or through information campaigns in the daily grocery stores.

The governmental effort is co-ordinated between the Ministry of Food, Agriculture and Fisheries, the Ministry of Trade and Industry and the Ministry of Health.

The Danish Veterinary and Food Administration has published several guidelines, for example the most recent "Guidelines on the interpretation of the number of aerobes found in foodstuffs manufactured or distributed at the retail stage", from January 1998, "Guidelines on the management of discoveries of Listeria monocytogenes in foodstuffs" from November 1998, and "Guidelines on the management of pathogenic microorganisms in foodstuffs" from 1999. The latter may guide the control authorities and the foodstuff producing companies in carrying out own check. 


\subsubsection{Denmark's Salmonella Control Programme}

The Salmonella action plan, launched in 1993, aimed at reducing the prevalence of Salmonella in primary pork production (raw pork). In order to limit the prevalence of Salmonella in pork the action plan comprises control of feeding stuff, livestock, and slaughter hygiene and production hygiene at abattoirs. Although the action plan against Salmonella in the pork production expired by the end of 1998, the government has decided that the plan should continue until the end of 2001.

In connection to the action plan for pork a national surveillance of Salmonella in meat and meat products was started in May 1993. Apart from products of pork, the surveillance includes raw meat, minced meat, and heat-treated meat products of beef and poultry, too.

In 1989, the poultry trade initiated an action plan (as a compulsory arrangement) for the prevention of Salmonella in chicken. In 1996, the government replaced the compulsory arrangement by a new three-year Salmonella action plan for the prevention of all Salmonella sero-types in breeding, rearing and egg producing flocks. By the beginning of year 2000, the responsibility for the continuation of the plan and the economic aspects hereof will be taken over by the industry.

In May 1998, the Veterinary and Food Administration prepared a risk assessment of Salmonella Typhimurium DT104, moult-resistant, in foodstuffs. They concluded that the bacterium is unacceptable in foodstuffs and that its presence should result in withdrawal of the foodstuff from the market for either destruction or heat treatment. Thus, the Veterinary and Food Administration initiated a specific action plan towards $S$. Typhimurium DT104. The aim of this ongoing plan is to prevent the consumers' exposure to the health risks of the micro-organism in foodstuffs, and to eliminate or reduce the prevalence and spread within and between livestock flocks. As part of the plan a surveillance and control program for meat and meat products was initiated in 1998.

In 1997 - 1998 the Veterinary and Food Administration carried out a survey of the occurrence of Salmonella in Danish and imported poultry in collaboration with the Danish Zoonosis Centre. The survey provided information on the Salmonella occurrence, the sero-type distribution and the resistance to anti-microbials.

In 1999, the Veterinary and Food Administration initiated an action plan in order to prevent the occurrence of Salmonella dublin in cattle. The objective of this action plan is to enable the determination of a "zero"-tolerance for the occurrence of $S$. dublin in food. Although rare, this specific micro-organism is the cause of more serious diseases in humans than those caused by other types of Salmonella. Although the surveillance project has started, not all aspects of the action plan have been fully negotiated with the industry yet (as of February 2000). The project is provided for in the Governmental Budget for the next three years. Hereafter the industry is supposed to take over.

\subsubsection{Food Safety Legislation}

Food safety in Denmark has previously been a very much-regulated domain. For example, the food-processing sector alone was previously regulated by seven Acts with approximately 125 orders and 600 circulars, guidelines, etc. In 1998, Denmark adopted a new Food Act (471/98). According to $\S 7$ in the Food Act, no food shall be sold if it is to be assumed that it may transmit or cause disease or result in poisoning. 
The Veterinary and Food Administration has been responsible for the preparation of the Act, which combines nine acts previously in effect in the whole foodstuff domain. Furthermore, the new act places the foodstuff control from farm to table within the purview of the Veterinary and Food administration under the Ministry of Food, Agriculture and Fisheries. The new act is fully implemented by January 1, 2000.

One of the objectives of the preparation of the new Food Act is to simplify the foodstuff legislation in order to enhance its applicability. In connection to the Act the Veterinary and Food Administration is now restructuring the rules and regulations into fewer orders in order to rationalise the legislation and fit the rules to the new regional control structure.

Thus, the new Veterinary and Food Administration no. 980/99 concerning the veterinary control of import of foodstuffs of animal origin replaces the previous order 1038/94 concerning import of animal foodstuffs and order 116/93 concerning import of fish and fish products. Please see section 6.1.6.

One of the more important orders in connection to microbiological food safety under the Food Act is order no. 1000/96 on Foodstuff Hygiene. The general objective of this order is to create a set of rules, which will promote safe and healthy foodstuffs. Chapter 6 in this order contains rules for provisions applicable to foodstuffs, temperature requirements, and rules concerning the sale, labelling and packaging of foodstuffs. In connection to the order on Foodstuff Hygiene the "Guidelines on Foodstuff Hygiene" elaborates and interprets the rules in the order. Furthermore, the "Guidelines on the Interpretation of the Number of Aerobes found in Foodstuffs Manufactured or Distributed at the Retail Stage", January 1998, is produced for use by the local control authorities. The aim of this guideline is to create a basis for a uniform interpretation of results.

The "Guidelines on the management of pathogenic micro-organisms in foodstuffs" from the end of December 1999 is a help to control authorities as well as companies during the management of findings of pathogens in foodstuffs. Furthermore, the "Circular on microbiological examinations of foodstuffs" from 1997 describes the microbiological methods used in connection to control of foodstuff companies. The circular describes the procedure and the obligatory parameters for each group of foodstuffs and microbiological methods based on indicators, etc.

The Veterinary and Food Administration order no. 992/99 concerning own check and the connected "Guidelines on own check" are concerned with the companies' obligation to ensure the safety of foodstuffs by means of the principles of HACCP.

The Zoonoses Act (1106/94), the Foodstuff Act (471/98), the Animal Diseases Act $(814 / 88)$, and the Feedingstuff Act $(282 / 1991)$ mentioned below plus new orders are now the basis for the Danish implementation of the EU Zoonosis Directive (92/117/EØF). By January 1, 2000, the Act on diseases and infections in Animals (351/99) replaces the Zoonoses Act and the Animal Diseases Act. One of the aims of the Act on diseases and infections in Animals is to protect human health by taking measures against the occurrence of zoonotic agents in animals, foodstuffs and other animal products. In connection to this act there are several orders concerning zoonoses. The DVFA order on the eradication of Salmonella in hens producing eggs for hatching (149/98) and order on the eradication of Salmonella in hens producing eggs for consumption (696/99) constitutes the legal instrument for the Salmonella action plan for poultry, which was launched in December 1996. The DVFA order on poultry control (244/99) and the order on hen's eggs for consumption (595/99) deal with the prevention 
of Salmonella in chicken flocks and spreading of Salmonella during packing and transportation, respectively. The DVFA order no. 245/99 deals specifically with the monitoring of Salmonella in poultry and the measures in connection to Salmonella Typhimurium DT104. Furthermore, the DVFA order no. 667/99 is concerned with monitoring of Salmonella in pigs and cattle and in raw pork and beef, and is concerned with the measures for findings of Salmonella Typhimurium DT104 in all animals.

The Feeding Stuff Act (282/91) and the connected Plant Directorate order 448/98 (with amendments 549/98, 961/98, 479/99 and 806/99) ensures the quality of animal production by setting standards for safe feeding stuffs, for example the maximum Aflatoxin concentration allowed. According to the Plant Directorate order on Salmonella-free feeding stuffs (677/97 with amendments 301/98 and 274/99), the Plant Directorate carries out the control of Salmonella in feeding stuffs. If Salmonella is present, the feeding stuff or raw material for feeding stuffs must be heat treated before further use. The Plant Directorate carries out the control of the feeding stuff manufacturers and their own check programmes according to order 745/98, and controls the imported feeding stuffs according to order 225/98.

The Epidemic Act (L 114/79) and the Ministry of Health order (1012/1993) concern the handling and notification of communicable diseases. Due to the Epidemic Act, each county has an epidemic commission consisting of representatives from medical officers of health, the police, the Veterinary and Food Administration, and the county council. The epidemic commission has authority to dictate quarantine arrangements, initiate microbiological examinations of individuals and initiate partial or full closure of foodstuff enterprises. Furthermore, medical practitioners are obliged to notify cases of illness with a clinical diagnosis and suspicion of a food borne disease. For further details of the notification system, see figure 3 .

\subsubsection{Overall Structure}

The following section concerns the overall structure of the organisational system and mentions various institutions involved in the work towards healthy foods for consumers in connection to microbiological risks, whether it be research (risk assessment) or specific work in food control (risk management).

As in the other Nordic countries, food control extends from farm to table in Denmark. The farm to table food control lies within two ministries: the Ministry of Food, Agriculture and Fisheries as mentioned above, and the Ministry of Health, which is responsible for surveillance of human incidences of food-borne diseases through the State Serum Institute and the medical officers of health. The control of drinking water lies within the purview of the Ministry of Environment and Energy.

The control of pathogens from farm to table is carried out by the companies producing or distributing food due to their own check obligations, which are described in the "Guidelines on own check", and the preventive efforts extend from primary production to the final product. The following state institutions participate in the surveillance and carry out research activities and prevalence surveys in connection to microbiological risks. 


\section{Danish Veterinary and Food Administration (DVFA)}

The Danish Veterinary and Food Administration's organisation is shown in fig. 1. DVFA is part of the Ministry of Food, Agriculture and Fisheries, and was founded July 1st, 1997, as the result of an integration of the National Food Agency and the Danish Veterinary Service. The merger enabled co-ordination, simplification and increase in the efficiency of both food inspection and food legislation. Thus, the regulation and control from farm to table is now the responsibility of a single authority.

The Veterinary and Food Administration is responsible for monitoring, controlling and fighting animal disease and zoonoses, and is the controlling authority with regard to practising veterinarians, the use of medicines for animals and compliance with animal protection rules. DVFA administers the Danish food legislation, and is responsible for research and control in the food and veterinary province in order to fulfil its aims. As of March 2000, DVFA is divided into two professional trust departments, which concern the veterinary service, and food legislation and food control. Furthermore, DVFA has an administrative department and two institutes for research and development (Institute of Food Safety and Toxicology, and Institute of Food Research and Nutrition, respectively). 


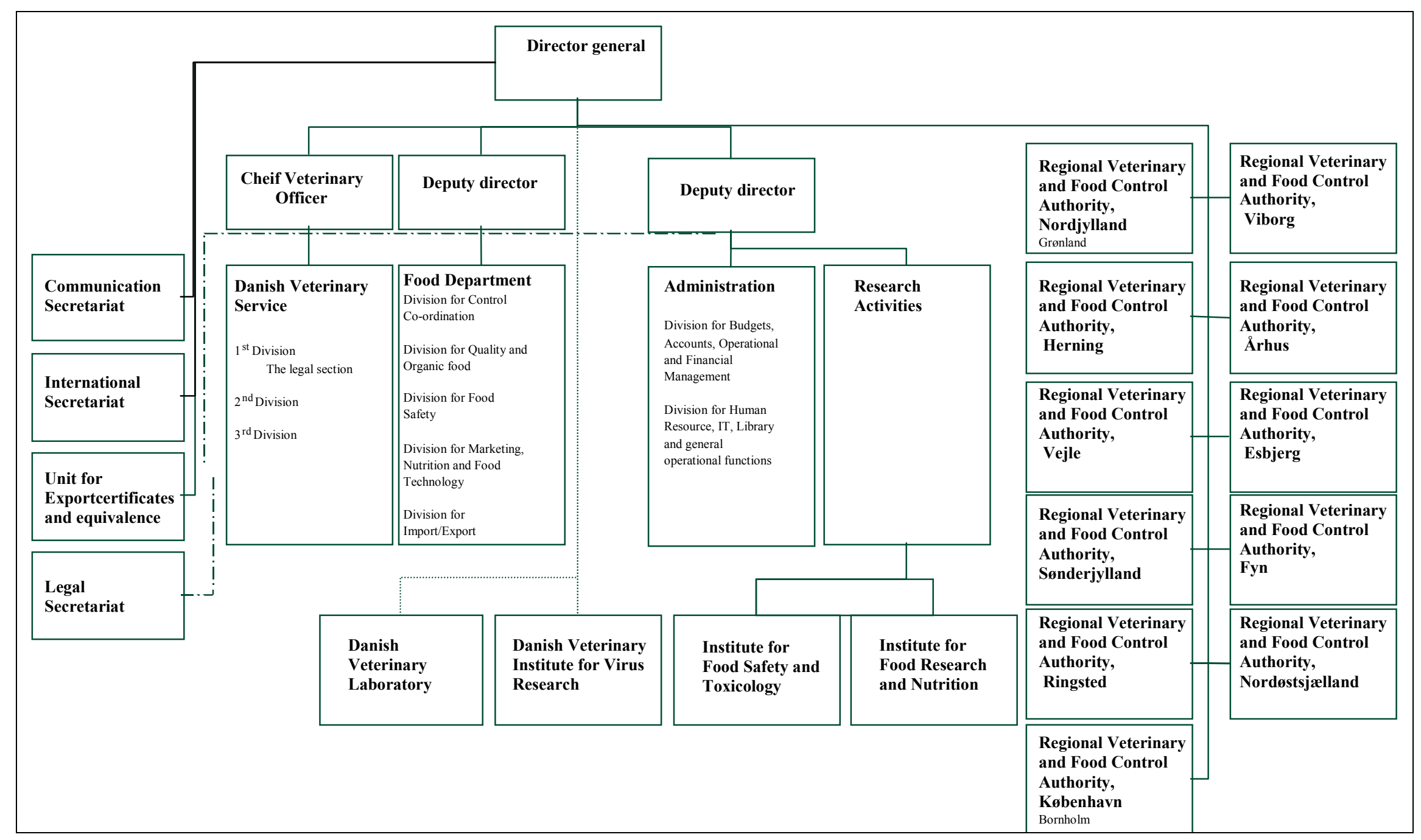

Figure 1. Organisation of the Danish Veterinary and Food Administration as of March 2000. 
The overall objectives of the Danish Veterinary and Food Administration are:

- To protect consumers against health risks and secure truthful labelling of products, and to promote sound eating habits.

- To safeguard the health and welfare of livestock and maintain Denmark's high veterinary standards.

DVFA carries out an extensive information activity aimed at consumers, companies and practising veterinarians.

The Danish Veterinary Laboratory and the Danish Veterinary Institute for Virus Research are affiliated with the Veterinary and Food Administration.

The new Danish Food Act (please see further description, section 6.1.3) provides the foundation for the establishment of one overall national food and veterinary inspection authority. Thus, from January 2000, 11 official Regional Veterinary and Food Inspection Units under DVFA will carry out all food inspection. These district offices will be established based on the existing regional and Border Veterinary Service, Meat Inspection Units, Municipal Food Inspection Units, and the relevant parts of the inspection system of the Danish Directorate for Fisheries and the Danish Plant Directorate. After January 1, 2000, the Veterinary and Food Administration will employ a staff of around 1900 people due to this amalgamation.

\section{Regional Veterinary and Food Inspection Authorities}

Each region, incorporating the tasks of the previous de-central control authorities as described above, is organised in the same way. They are autonomous authorities, which are headed by a regional manager and consists of a food department, a veterinary department, a laboratory and a secretariat.

In connection to food safety each Regional Veterinary and Food Inspection Authority is responsible for:

- Authorisation, certification, registration, inspection and control of foodstuff enterprises, at all stages of the stable to table processing step

- Issuing certificates of health, export certificates, etc.

- Import control and control of products of animal origin within the EU, for example Salmonella control

- Import control of fish foods and fish products from countries outside EU, except after direct entrance of fresh fish

- Market control with fresh fruit and vegetables at wholesale and retail levels

The 11 Regional Veterinary and Food Inspection Authorities will collaborate on large information campaigns in order to ensure an effective and uniform effort throughout the country.

Data are from microbiological examinations of foodstuffs is entered the DVFA microbiological database. The microbiological database contains the results of all the tests 
carried out in accordance with the government circular concerning microbiological examinations of foodstuffs. Furthermore, the database contains results from various surveillance programmes on pathogenic bacteria in foodstuffs.

The new structure replaces the previous control structure, where a number of veterinarians, employed in the Meat Inspection, performed inspection at the abattoirs. The Danish Veterinary and Food Administration, who received the economical funds from the abattoirs, paid and employed the Meat Inspection personnel. At the retail stage, the Municipal Food Inspection Authorities were responsible for the foodstuff control. These Food Inspection Units reported directly to DVFA. Before January 2000 there were $32 \mathrm{Mu}-$ nicipal Food Inspection Authorities, whereas after January 2000 the new regional structure has resulted in the eleven Regional Veterinary and Food Inspection Authorities described above.

\section{Danish Veterinary Laboratory (DVL)}

The Danish Veterinary Laboratory is a sector research institution accountable to the Veterinary and Food Administration, and constitutes an integral part of the Danish Veterinary Contingency Plan. The overall objective is to assist in the prevention and control of zoonoses (see the Zoonosis Centre mentioned below) and the prevention of diseases in livestock. The aim is to promote safe and healthy food for the consumers and to promote production conditions securing animal health and welfare. Furthermore, DVL works to promote prudent use of anti-microbial agents to maintain their efficacy of the treatment of animals and to avoid spread of anti-microbial resistant bacteria from animals to humans and to the environment. DVL employed 395 persons in 1998.

\section{Danish Zoonosis Centre (DZC)}

As part of the implementation of EU's Zoonosis Directive, a research centre for zoonoses has been established at the Danish Veterinary Laboratory. The Danish Zoonosis Centre conducts surveillances and analyses data concerning zoonotic infections (diseases that can be transferred from animals to humans) and anti-microbial resistance in bacteria in animals, in food, and in humans. It is responsible for the epidemiological treatment of data concerning infectious zoonotic matters in the production of domestic animals and foodstuffs. Through this work, the importance of infectious agents in domestic animals and foodstuffs in relation to human incidence of diseases is continuously monitored. The Danish Veterinary Laboratory (Danish Zoonosis Centre) conducts research and development in order to acquire a research-based knowledge of animal diseases and zoonoses, and to possess analytical material for diagnosing animal diseases and zoonoses as well as methods for tracking food-borne zoonoses. The work of the Zoonosis centre concerning tracking of food-borne zoonoses is concerned with sporadic events as well as food borne outbreaks of disease. The Danish Zoonosis Centre issues a newsletter for veterinarians, physicians, and public authorities and trade organisations, and publishes a report on zoonoses annually. 


\section{Danish Veterinary Institute for Virus Research (DVIV)}

DVIV constitutes an integral part of the Danish Veterinary Contingency Plan. It is a sector research institution accountable to the Veterinary and Food Administration. Its overall objective is to contribute to the prevention and eradication of animal viral diseases in Denmark, and thus to contribute to the production of healthy animals and animal products for the benefit of consumers and farmers.

\section{Danish Plant Directorate}

The Plant Directorate is responsible for the duties of the ministry in the areas of quality and health of vegetable products, environmental regulation of agricultural production, and control of EU agricultural subsidy schemes. The Plant Directorate employed 499 persons in 1998. Work procedures are based on national legislation, EU regulations and international rules. The directorate undertakes legislative work within its own domain. The assignments of the Plant Directorate include the inspection of seed and cereal seed, feed and fertilisers, plant and plant health, fruit and vegetables, potatoes, organic farming, forestry, seed and plants. All companies producing or selling feeding stuffs must register and eventually be approved by the plant Directorate. In order to prevent the presence of Salmonella in feeding stuffs, the Plant Directorate carries out spot checking of the raw materials for feeding stuff production as well as the final product. Control is implemented using sampling and laboratory tests as well as farm visits. Six district offices around the country undertake the inspection of companies and farms.

\section{Danish Directorate for Fisheries}

The main objective of the Danish Directorate for Fisheries is to carry out efficient management and control of EU regulations and national rules in the fisheries sector in order to ensure and appropriate use of the fish resources. Furthermore, the Directorate also performs quality inspection in companies and in import/export transactions with the purpose of ensuring healthy food products for the consumers. The Directorate employed 330 employees in 1998.

\section{Danish Directorate for Development}

The main goal for the Danish Directorate for development is to promote the structural adjustment and development of the food sector, including farming and fisheries. The directorate is responsible for industrial promotion, structural adjustment, and research and development in the food sector, including farming and fisheries.

\section{Danish Institute for Fisheries Research (DIFRES)}

DIFRES is a sector research institution, whose activities deal with the whole chain from water to table. DIFRES acts as a counsellor to the Ministry of Food, Agriculture and Fisheries as the institution belong under the Danish Directorate for Development. The Institute takes part in international research co-operation as consultants to national and international authorities on sustainable fisheries management. 
The aim is, through research, to enhance the understanding of the aquatic systems and covers live resources and their environment, including the impact of fishing and natural changes on fish production. At the microbiology group, the research conducted includes pathogenic micro-organisms and safety of seafood, spoilage and shelf life of seafood, and natural antibacterial systems/biopreservation strategies.

\section{State Serum Institute (SSI)}

SSI, under the Ministry of Health, is the central laboratory for the Danish Health Service, and is its centre for prevention and control of infectious diseases. SSI carries out a wide range of expert tasks for the central health authorities and Denmark's hospitals. SSI's activities encompass special diagnostic analyses and advisory functions in microbiology, clinical biochemistry, etc., primarily supplied to Danish hospitals and general practitioners. Among SSI's main activities are surveillance, advisory and reference functions for Danish and international health authorities. A collaboration agreement on hygiene and health has existed between the former National Food Agency (now DVFA) and SSI since 1995 when the former National Food Agency belonged to the Ministry of Health. The agreement promotes the exchange of information concerning microbiology and the co-ordination of hygienic initiatives with the aim of increasing the efficacy of various preventive strategies.

\section{The new regional control structure.}

Figure 2 shows the structure of the food control system in Denmark. The figure reveals the relative simplicity of the new one-line structure, which was initiated in 1996 by means of the establishment of the Ministry of Food, Agriculture and Fisheries. The Veterinary and Food Administration is responsible for food inspection all the way from stable to table. Food inspection and all official livestock inspection are now centralised at 11 official Regional Veterinary and Food Inspection Authorities. The new regional structure was implemented in January 2000. It replaces a structure in which the control tasks, now centralised at the Regional Veterinary and Food Inspection Authorities, were previously carried out by the following authorities:

- Municipal Food Inspection Units

- The regional Veterinary Service

- Meat Inspection Units

- Border Veterinary Service

- The Directorate for Fisheries, part of the fish inspection service

- The Plant Directorate, parts of the inspection of fruit, vegetables, potatoes and cheese 


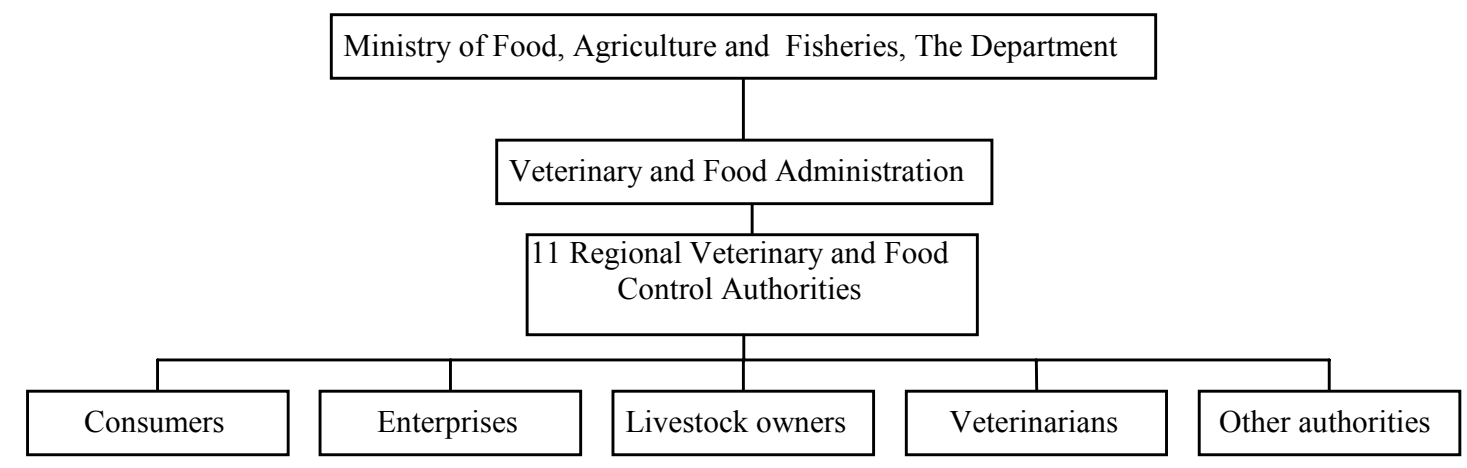

Figure 2. Organisation of food control from stable to table in Denmark (as of January 2000).

When a food borne outbreak is detected at the central level either at the Danish Veterinary and Food Administration or at the State Serum Institute, the information is passed on through the organisational system according to the "Guidelines on the notification of outbreaks of food borne diseases" (figure 3).

The Veterinary and Food Administration can obtain information from authorities in countries outside EU via the "Rapid Alert System" of, whether or not imported foodstuffs have caused food borne diseases.

When an outbreak is detected locally, the relevant Food Inspection Unit is responsible for notifying the relevant District Medical Officer. The Veterinary and Food Administration must be notified if the suspected foodstuffs have been distributed within a larger area, or if the case may be of general interest.

The medical doctors are obliged to report cases of food borne disease to the District Medical Officer if a clinical diagnosis exists and if a certain meal or foodstuff is suspected to have caused the particular symptoms. The District Medical Officer then reports to the Food Inspection Units and the information flows further through the organisational system as visualized in figure 3 .

While bottled drinking water lies within the purview of the Ministry of Food, Agriculture and Fisheries, the notification of water-borne diseases is not encompassed by these guidelines, as tap water is within the purview of the Danish Environmental Protection Agency. 


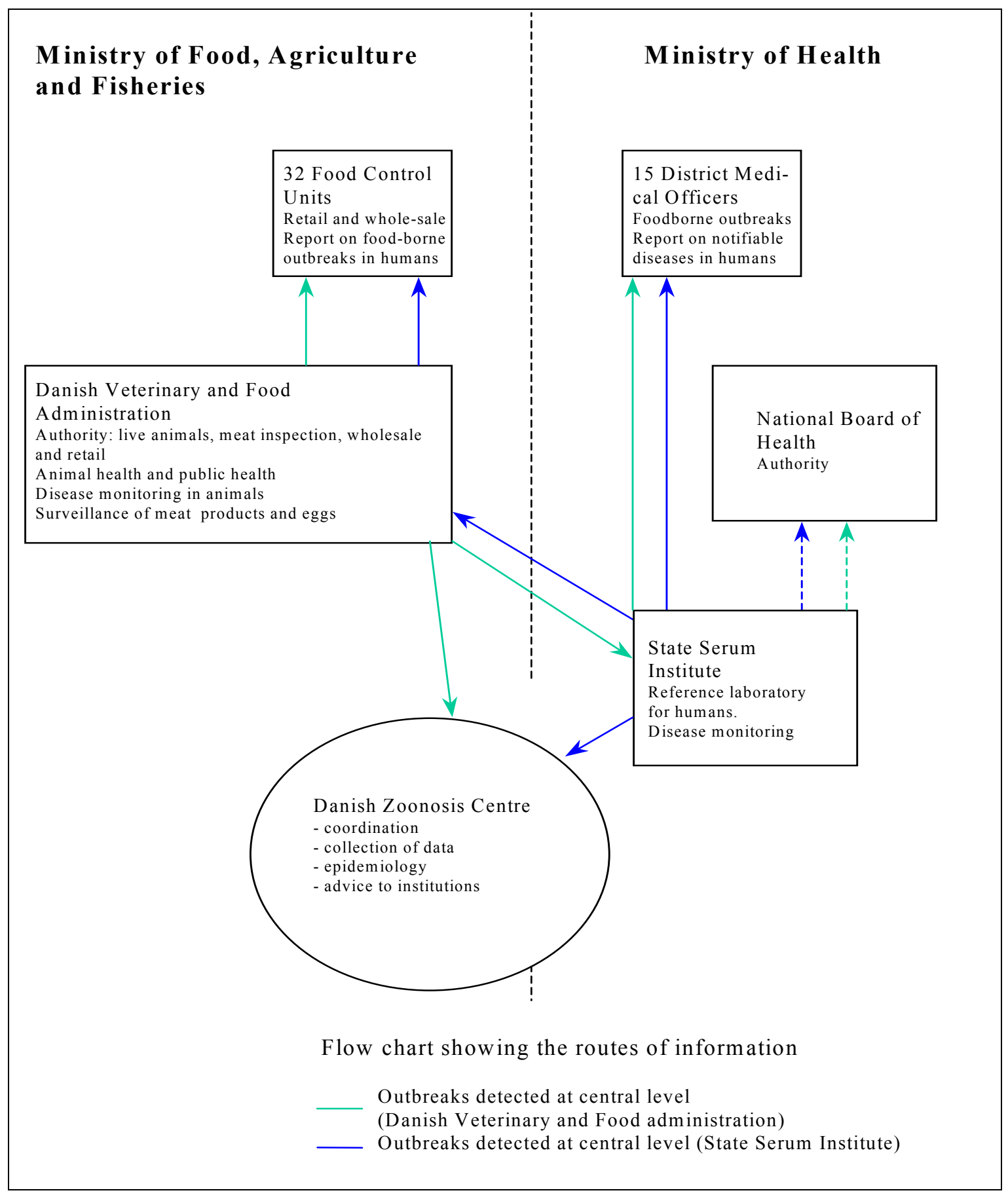

Figure 3. The notification system for food borne outbreaks detected at central level in Denmark until the end of 1999. (By 1 January 2000, 11 regions replaced the 32 Food Inspection Units.) 


\subsubsection{Zoonosis Network}

The Veterinary and Food Administration collaborate with other institutions within the Ministry of Food, Agriculture and Fisheries. Thus, the Administration instructs the Directorate of Fisheries, which carries out the control of matters concerning fish or fish products (Act 167/65) on behalf of the Veterinary and Food Administration. Furthermore, the Veterinary and Food Administration acts as a counsellor for the Danish Environmental Protection Agency under the Ministry of Environment and Energy in its work with chemical compounds and gene technology. Furthermore, the Veterinary and Food administration participates in the co-operation in all the international organisations, which deal with veterinary and food issues.

A collaboration agreement exists between DVFA and the State Serum Institute with the aim of increasing the efficacy of various preventive strategies.

Please see the description of the Danish Zoonosis Centre above. (Section Overall Structure). The microbiological data which are generated through the various surveillance and control programmes and surveys are collected and reported in the annual report on zoonosis. Furthermore, the data are presented ad hoc in the monthly periodical "Zoonose-News" published by the Zoonosis Centre.

\subsubsection{Control and Registration of Imported Food}

The control and registration of imported foodstuffs is subject to the EU regulation. It obeys the then existing Danish Veterinary Service order 1038/1994 concerning import of animal foodstuffs and the then existing Ministry of Fisheries order 1166/1993, concerning import of fish and fish products. Imported foodstuffs of animal origin from a third country (a country outside EU) are inspected at the nearest border inspection post (BIP) when entering EU. The importer pays for this inspection. The border inspection posts was subordinated the new regional structure by the beginning of year 2000 .

When foodstuffs of animal origin are imported to Denmark from another EU country, the importer is responsible for the control. However, the Food Inspections may carry out spot-checking, which will then be paid for by the Danish state. Guidelines exist concerning the spot checking of foodstuffs imported to Denmark from another EU country, for example the "Guidelines on the control of Salmonella Typhimurium DT104, multiresistant, in pork, beef and poultry imported from other EU countries or third countries". In accordance with these guidelines $5 \%$ of the imported pork and beef lots are examined, whereas $10 \%$ of the imported poultry lots are examined at companies or border inspection posts.

By January 1, 2000, the new order no. 980/99 concerning the veterinary control of during import of foodstuffs of animal origin replaced the two orders mentioned above.

Table 1 shows consumption, import data and degree of self-sufficiency for selected groups of foodstuffs. The imported amount relative to the consumed amount is smallest for pork meat (less than $7 \%$ ), whereas the import quantity of sheep meat is comparable to the consumed. The imported amount of poultry makes up almost thirty percent of the consumed amount. The import quantity of eggs and egg products has more than doubled between 1996 and 1998, while the self-sufficiency decreased. The same tendency is seen for the grain and flour foodstuff group. 
Table 1. Foodstuff consumption, import (nearest million $\mathrm{kg}$ ), and self-sufficiency (percentage) in Denmark 1996 and 1998. ${ }^{a}$ Various major foodstuff groups.

\begin{tabular}{|l|cc|cc|cc|}
\hline Foodstuff & \multicolumn{2}{|c|}{$\begin{array}{c}\text { Human } \\
\text { Consumption }\end{array}$} & \multicolumn{2}{c|}{ Import } & \multicolumn{2}{c|}{$\begin{array}{c}\text { Production in \% } \\
\text { of human } \\
\text { consumption }\end{array}$} \\
& $\mathbf{1 9 9 6}$ & $\mathbf{1 9 9 8}$ & $\mathbf{1 9 9 6}$ & $\mathbf{1 9 9 8}$ & $\mathbf{1 9 9 6}$ & $\mathbf{1 9 9 8}$ \\
\hline Cheese & 89 & 87 & 32 & 32 & 337 & 336 \\
Beef \& veal & 108 & 110 & 63 & 77 & 182 & 159 \\
Pork & 361 & 354 & 18 & 24 & 428 & 475 \\
Poultry & 80 & 93 & 22 & 26 & 208 & 199 \\
Sheep & 6 & 6 & 5 & 6 & 33 & 25 \\
Eggs \& egg products & 74 & 86 & 11 & 26 & 105 & 86 \\
Grains \& flour & 443 & 478 & 140 & 214 & 107 & 85 \\
Potatoes & 299 & 301 & 184 & 227 & 434 & 462 \\
\hline
\end{tabular}

a) Reference: Statistics Denmark.

\subsubsection{Monitoring/Surveillance of Zoonotic Pathogens}

\subsubsection{Salmonella}

\section{Feeding-stuffs}

The Danish Plant Directorate monitors all Danish feed compounds for Salmonella. Furthermore, the Plant Directorate collects samples of feeding stuffs from the production plants and retailers. At least four times a year, plant inspectors carry out process control at feed processing plants. The samples are collected for microbiological examination at the critical control points of the production process. If Salmonella is detected in the samples or critical hygiene conditions are reported, additional inspections are carried out at the plant.

\section{$\underline{\text { Rendering plants }}$}

The animal health section of the Danish Veterinary and Food Administration carries out the control of hygiene at rendering plants.

\section{Poultry and poultry products}

Since December 1996, parent flocks, rearing flocks and layer flocks have been tested for all Salmonella serotypes. The frequency of testing can be seen in the Annual Report on Zoonoses in Denmark, 1999. In autumn 1999, the faecal samples collected in rearing and layer flocks changed to so-called "sock-samples" in floor production units. This methods is carried out by mounting gauze on the footwear during inspection of the house. The method has at least the same sensitivity as 60 faecal samples, and is easier to perform.

In 1999, no central rearing flocks were found infected with Salmonella. Others

In broiler production, all broiler flocks were monitored for Salmonella by mandatory ante-mortem examination. And five pairs of sock samples were collected from each 
flock three weeks prior to slaughter. At post-mortem sampling, five pooled samples consisting of 10 neck-skin samples from each slaughter flock are analysed.

All turkey flocks are analysed for Salmonella by mandatory ante-mortem examination.

In April 1999, Salmonella monitoring was started in duck and goose flocks by antemortem examination.

A serological surveillance programme for the detection of Salmonella infection in slaughter-pig herds was implemented at the beginning of 1995 . Thus, all herds producing more than 100 pigs for slaughter per year are monitored by serological testing of meat juice. Above a certain positive level, pen-faecal samples are required. Breeding and multiplying herds are monitored monthly by serological testing of blood samples. Above a certain positive level, pen-faecal samples are required, and eventually all movement from the livestock is restricted. A programme for monitoring of Salmonella in pork at the abattoirs was initiated in July 1993. Approximately 2.250 samples were analysed each month. For each slaughterhouse, the actual number of animals slaughtered determines the number of samples collected.

Herds of cattle are investigated for Salmonella on clinical indications and as part of a monitoring programme of the occurrence of anti-microbial resistance in zoonotic bacteria.

The Regional Veterinary and Food Inspection Authorities collect samples for monitoring Salmonella in meat and meat products at the retail level.

\section{Other}

The Danish Veterinary Laboratory monitors the occurrence of Salmonella in pet animals and wildlife. The group of wild mammals and birds consists mainly of animals found dead in nature. Pet animals are investigated on clinical indications only.

\section{$\underline{\text { Humans }}$}

Outbreaks of food- and waterborne infections caused by zoonotic agents may be detected with three different systems. Firstly, the physicians are obliged to notify all infections which are suspected to be food borne. Secondly, individuals, who experience food poisonings often report these incidents to the Regional Veterinary and Food Inspection Authorities. These results are collected at the Danish Veterinary and Food Administration. Thirdly, the gastrointestinal pathogens identified at clinical microbiology laboratories are reported to the department of gastrointestinal infections at the State Serum Institute.

\subsubsection{Others}

\section{Campylobacter}

In 1998, a national monitoring of thermophilic Campylobacter in broilers, hens and ducks was initiated. At slaughter, ten birds per flock were examined by cloacal swaps. As part of the monitoring programme of the occurrence of anti-microbial resistance in zoonotic bacteria from pigs and cattle, caecal contents were sampled at slaughter houses and examined for thermophilic Campylobacter as well. One animal per herd was sampled.

In food, a nation-wide surveillance programme of thermotolerant Campylobacter in poultry products from retail outlets was established in 1996. 


\section{$\underline{\text { Listeria }}$}

According to Danish rules investigations of the levels of L. monocytogenes in food are to be performed on certain ready-to-eat products at routine examinations.

\section{Mycobacterium bovis}

Danish cattle herds are declared officially free from bovine tuberculosis since 1980 . The disease is notifiable in Denmark. Monitoring is performed by meat inspection at slaughter.

\section{Brucella abortus/melitensis}

Denmark has been regarded officially free from brucellosis in cattle since 1979. Brucellosis is a notifiable disease, and monitoring is performed by examination of abortion material.

\section{Trichinella spiralis/nativa}

All pigs slaughtered for export are examined for Trichinella. The disease has not been found in Danish pigs since 1930.

\section{$\underline{\text { Surveys }}$}

For zoonotic agents, not mentioned above, surveys have been carried out regularly for, for example: VTEC (O157) in cattle and food, Yersinia enterocolitica in pork and pork products.

\subsubsection{Monitoring/Surveillance of Anti-microbial Resistance}

The Danish Integrated Anti-microbial Resistance Monitoring and Research Programme (DANMAP) was initiated in 1995. DANMAP monitors anti-microbial resistance in bacteria from food animals, foods and humans and has been designed to provide a basis for comparison of the occurrence of resistance in these reservoirs. Furthermore, DANMAP reports data on the consumption of anti-microbials in animals, in humans, and on associations between the use of anti-microbials and trends in anti-microbial resistance. The information is published annually in the DANMAP reports, which are also available on the Internet, at the homepage of the Danish Veterinary Laboratory (DVL). The report is produced in collaboration between the Danish Veterinary Laboratory, The Veterinary and Food Administration, Danish Medicines Agency and the State Serum Institute. In addition to the resistance monitoring, DANMAP includes considerable research activity. The Ministry of Food, Agriculture and Fisheries and the Ministry of Health jointly fund the DANMAP programme. See the description of the Danish Zoonosis Centre above.

\subsubsection{Risk Assessment Activities}

While the risk management work is primarily carried out at the administrative offices at DVFA (where the regulation work is mainly carried out by lawyers, and the control work by veterinarians as well), the work on risk assessment is mainly carried out at the Institute of Food Safety and Toxicology at DVFA.

A pathogen account, which is an estimate of the sources of human salmonellosis, based on sero-, phage- and DNA-typing, is prepared annually for Salmonella by the Danish Zoonosis Centre (figure 4). The knowledge of the sources of human salmonellosis has 
been applied in the risk management process and has lead to the implementation of a number of Salmonella action plans.

General descriptions (risk profiles) of the problems in connection to Campylobacter and E. coli $\mathrm{O} 157$ in Denmark have been prepared by the Veterinary and Food Administration in collaboration with the State Serum Institute, the Veterinary Laboratory, The Consumer Council and trade organisations.

Furthermore, in 1999, due to the Ministry of Food, Agriculture and Fisheries' pathogen strategy from 1998, the Veterinary and Food Administration and the Danish Veterinary laboratory began a research-based risk assessment of Campylobacter and E. coli $\mathrm{O} 157$ in Denmark.

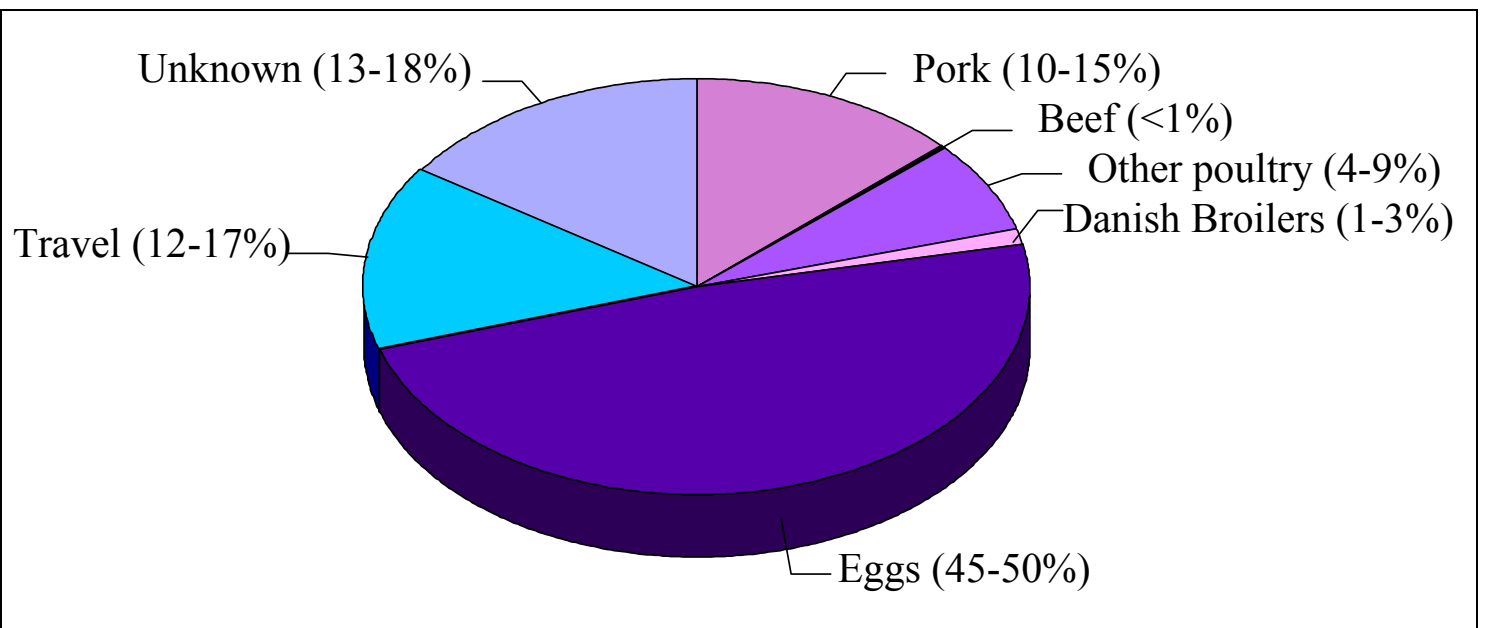

Figure 4. Salmonella Pathogen account, 1998. (Danish Zoonosis Centre)

In connection to a SCOOP project, DVFA has prepared a preliminary risk assessment model on liquid pasteurised eggs. In this preliminary model calculated contamination levels were applied for the exposure assessment. This risk assessment model will be elaborated in a future project involving the evaluation of the calculated contamination level in liquid pasteurised eggs.

\subsubsection{Strengths and Weaknesses of the Danish System}

\subsubsection{Strengths}

- Lots of retail data

- Local control has been made national by the state

- Same ministry throughout the farm-to-table chain

- Thus more cost-effective control

- Good collaboration between the Nordic countries, and inside the countries (exchange of information)

- Research efforts can be planned to cover a larger spectrum of parameters, and the most relevant issues in connection to public health can be emphasised 
- Lots of data throughout the food chain

- DANMAP extends from the farm to the human being

- FSOs exist for Listeria, Salmonella DT104, and Salmonella in general.

\subsubsection{Weaknesses}

- Reduction of human food-borne disease: Several areas are still without food safety objectives.

- To some extent, pathogens are still monitored by means of indicator bacteria, which is a less relevant parameter in connection to health than specific pathogens, and therefore, risk management decisions are made more difficult. Analysis is directed towards parameters that are not a risk, and therefore, resources are directed more towards quality control than towards actual food safety

- The resources used on surveillance's/monitoring may be large in comparison to the use of the large amount of data.

- A comprehensive description of the surveillance of food-borne diseases in DK has not yet been prepared.

- While bottled drinking water lies within the purview of the Ministry of Food, Agriculture and Fisheries, the notification of water-borne diseases is not encompassed by these guidelines, as tap water is within the purview of the Danish Environmental Protection Agency.

- Risk management is seldom carried out in accordance with Codex guidelines

\subsubsection{Acknowledgements}

The following people are acknowledged for their help during the preparation of this section:

DVFA: Søren Aabo, Annelise Andersen, Kirsten Daniels, Jørgen Kruhl Jensen, Marianne de Leon, Anette Perge, Maya Regel Pundick, and Lene Rasmussen. WHO Copenhagen: Tine Rikke Jørgensen. 


\section{$2.2 \quad$ Finland}

\subsubsection{Overall National Policy}

\subsubsection{Food quality strategy from 'farm to table' in Finland}

In our view, the safety of foodstuffs can be established only by making sure the raw material is safe. However, the whole production chain must be aware of the options and responsibilities in producing safe food for the consumers. This risk management work, carried out for decades, has been lately built up in the common quality strategy from "farm to table".

A national food quality strategy has been launched in Finland. The project was started in 1996. The entire production chain, from agricultural producers and industry to advisory bodies, trade, research and administration, is working systematically together to ensure high quality of foodstuffs. The aim is to adopt internationally approved quality and environmental management standards in agriculture, agricultural input industry, food industry and trade by the year 2006. The intention is also to improve the competitiveness of agriculture and food production. In short, the challenge is threefold: quality, competitiveness and safety of food and agricultural production.

The Ministry of Agriculture and Forestry directs the national food quality strategy. The agricultural input industry, food industry, trade, agricultural producers, consumers and research bodies participate in this work. The duty of the public authorities is to give priority to improving the quality of food in all decision-making. The authorities intend to direct more resources into monitoring, research, training and provision of information.

Main concerns of food quality are:

- foreign substances in food

- undesirable substances and products in feed

- use of anti-microbial agents to suppress microbial growth

- use of hormones

- animal diseases communicable to human beings (zoonoses)

- animal diseases

- plant diseases and pests

- use of pesticides

Quality is assured in all sections of the production chain with systematic quality work. The tools used in quality work include internationally recognised quality and environmental systems for which there are ready-made certification procedures. Each participant will apply quality and environmental standards and agreements to ensure that operations and food quality meet the changing needs of consumers. 
The goals have been set for year 2006:

- agriculture is within sphere of systematic quality work

- industry and trade in agricultural produce have quality and environmental systems ready for certification

- the food trade has a quality and environmental system for logistics and trading

\subsubsection{Finland's Salmonella control programme}

See below section 1.1.6.

\subsubsection{Food Safety Legislation}

The Feeding Stuffs Act (396/1998) aims to ensure the quality of animal production and foodstuffs of animal origin by maintaining and improving the quality and safety of animal feeding stuffs. Decisions of the Ministry of Agriculture and Forestry regulate the import, production, marketing, approval and control of animal feeding stuffs. The Plant Production Inspection Centre (KTTK) carries out official control according to a control plan, which is annually approved by the Ministry. The manufacturers of feed materials, com-pound feed and feed additives are subject to continuous monitoring by KTTK. For ex-ample, Salmonella samples are taken from imported feeding stuffs and feeding stuffs available on the market or of domestic production. In the recent years, an own check programme has been established by most of the feed manufacturers. In accordance with the new feed regulations the own check programmes can be approved by KTTK for adjusting their official control.

The Animal Disease Act (no. 55/1980, amended by 809/1992, 424/1994, 1193/1996, 491/1997, 1000/1997 and 398/1998) stipulates the principles of combating and preventing animal disease. By the Animal Disease Act, an animal disease refers to such illness or infection that can be transmitted directly or indirectly to another animal or person. A zoonosis may be considered an animal's disease to be combated if the infection causes a serious illness in humans. In addition, more detailed regulations on the combating and control of certain zoonoses, such as brucellosis, salmonellosis and tuberculosis, are laid down in Decisions of the Veterinary and Food Department of the Ministry of Agriculture and Forestry.

The control of foodstuffs and their handling is mainly based on three acts. These are the Act on Hygiene of Foodstuffs of Animal origin (Hygiene Act, 763/1994), the Food Act (361/1995) and the Health Protection Act (763/1994). The purpose of the Hygiene Act is to secure the quality of foodstuffs of animal origin and to prevent the spread of infection from animals to humans via foodstuffs. The objective of the Food Act is to secure the safety of foodstuffs and to protect the consumers against harm to health caused by foodstuffs unfit for human consumption. In accordance with the Health Protection Act, if a foodstuff can be assumed to have caused food poisoning, the company that handled the foodstuff must report this to the municipal health protection authorities.

The Act on Infectious Diseases (583/1986, amended 76/1991, 770/1992) obliges medical practitioners to file a report on a suspected or verified case of a generally dangerous infectious disease or a notifiable infectious disease, as well as requiring the microbiological laboratory to report any findings indicating such diseases. The Regulation 
1997:34 lists the microbes to be reported by the microbiological laboratories and provides for the reporting procedure and maintaining of the National Register on Infectious Diseases. Furthermore, the Ministry of Social Affairs and Health has issued a special regulation on the monitoring and reporting of cases of food- and waterborne outbreaks (1997:1).

\subsubsection{Overall Structure}

\subsubsection{Description of organisations}

Food control in Finland extends from the farm to the table. In order to control risks in food production it is essential to take systematic, active and preventive measures at the early stages of the food chain in primary production and at the level of agricultural production inputs, e.g. animal feed, fertilisers, pesticides and on the farm. Salmonella control in animal feeding stuffs has been carried out over 40 years.

Food control from farm to table in Finland falls within the purview of four government ministries: the Ministry of Agriculture and Forestry, the Ministry of Trade and Industry, the Ministry of Social Affairs and Health and the Finance Ministry (figure 5). Their tasks are explained briefly below.

The Unit for Quality Policy in the Department of Agriculture of the Ministry of Agriculture and Forestry

The Unit for Quality Policy has the responsibility for the legislation, action policy and overall guidance of control in the primary agricultural production covering the following areas: animal feeding stuffs, fertilisers, seed, propagating materials, pesticides, plant health and organic farming. Aim is to ensure a good safety, hygiene and quality level of agricultural production materials as well as a high level of plant health. The Unit sets the objectives for the Plant Production Inspection Centre (KTTK), the SPK-Seed Potato Centre and yearly approves control plans and participates in developing control systems.

\section{The Veterinary and Food Department of the Ministry of Agriculture and Forestry}

The Veterinary and Food Department of the Ministry of Agriculture and Forestry handles veterinary matters falling within the EU directorate SANCO of the European Commission and also certain matters of veterinary medicine falling within the EU directorate Enterprises. The Department's objective is to prevent contagion from animals to humans, to ensure a good level of hygiene in foodstuffs of animal origin, to safeguard the health and welfare of animals and to undertake preventative measures and monitoring of infectious animal diseases.

The Veterinary and Food Department prepares and drafts veterinary legislation. It is also in charge of supervising animal medication, animal diseases and animal welfare. The department monitors the practice of veterinary medicine and is responsible for border inspection of live animals as well as foodstuffs and other products of animal origin from countries that are not members of the European Union. In addition, the Department sets the objectives of the National Veterinary and Food Research Institute (EELA) and the provincial state offices. 


\section{Ministry of Social Affairs and Health}

The Department for Promotion of Welfare and Health in the Ministry of Social Affairs and Health has the responsibility for implementation of general food hygiene legislation concerning food of non-animal origin and food at the retail level. The Department also prepares the legislation concerning the notification of transmissible diseases and notifications of food and waterborne outbreaks.

\section{$\underline{\text { Plant Production Inspection Centre (KTTK) }}$}

KTTK under the Ministry of Agriculture an Forestry is responsible for agricultural inspection and aims to ensure high-quality plant and animal production. It implements legislation concerning animal feeding stuffs, fertilisers, seed, propagating materials, pesticides, plant health and organic farming. In the area of feed materials of animal origin, it also implements veterinary legislation to control the manufacture, import, export and marketing of the corresponding products. On regional and local level the control work is carried out by authorised inspectors and samplers as well as the regional agricultural authorities all over Finland (Rural Departments of the Employment and Economic Development Centres). KTTK co-ordinates this work, and practical control activities are based on annual control plans given by KTTK. In addition, in import control KTTK is assisted by the National Board of Customs.

\section{The National Veterinary and Food Research Institute (EELA)}

EELA is an institution within aegis of the Ministry of Agriculture and Forestry that studies animal diseases, directs and supervises the control of foodstuffs of animal origin and is responsible for the meat inspection in slaughterhouses. EELA carries out research work related to animal diseases and to the safety and quality of foodstuffs of animal origin. Consultation of questions of food hygiene and the prevention of animal diseases is an important part of the EELA's operation. It serves as the national, accredited reference laboratory in studies of animal disease, foodstuffs of animal origin, and residues.

EELA draws up national programmes for supervision of residues in foodstuffs of animal origin and Salmonella each year and monitors their implementation. The Salmonella control programme is described briefly below. EELA compiles examination results from laboratories in a national register and makes an annual report to the Veterinary and Food Department. EELA's Department of Food Control leads and directs supervision throughout Finland of the regulations of the Food Hygiene Act and its statutes, including supervision of foodstuffs of animal origin traded within the Single European Market. EELA certifies slaughterhouses and connected establishments. It arranges meat inspection in all slaughterhouses except reindeer slaughterhouses. EELA maintains a register of establishments and first destinations handling foodstuffs of animal origin. EELA certifies the food control laboratories and maintains a register of them in accordance with the Food Hygiene Act. 


\section{National Food Administration (NFA)}

NFA, under the Ministry of Trade and Industry, co-ordinates and directs the food control under the Food Act (361/1995) and the Health Protection Act (763/1994) on retail level. With foods of plant origin NFA also directs the control of food processing. It supports municipalities through control and research projects, arranges the implementation of EU food control projects in Finland, issues interpretations and control guidelines, develops food control laboratory's activities, collects information on municipal food control, monitor the quality of control, develops registers and files and arranges the active change of information. At the end of 1998, the official food laboratory register of the National Food Administration included 32 laboratories.

The Ministry of Social Affairs and Health is the competent authority for the implementation of the general food hygiene legislation. The National Food Administration serves as the central body for the practical implementation of the food hygiene legislation.

Together with EELA, NFA arranges a considerable amount of training of municipal and other authorities. The two organisations publish a joint calendar of training events related to food control. They also prepare an annual food control programme together.

\section{$\underline{\text { National Public Health Institute (NPHI) }}$}

NPHI, under the Ministry of Social Welfare and Health, is a research Institute for public health. It consists of three divisions: Infectious Diseases, Environment, and Chronic Diseases. Each division has laboratory and epidemiological functions. In various ways, NPHI supports the health authorities at the local, regional and national levels in the surveillance and control of important disease problems. The Department of Infectious Diseases Epidemiology is responsible for implementing the epidemiological surveillance of infectious diseases. The Laboratory for Enteric Pathogens is the national reference laboratory for enteric bacterial infections. These units also liase with relevant international authorities in surveillance and control of infectious diseases.

\section{$\underline{\text { Provincial state offices }}$}

The provincial state offices are responsible for overseeing inspection required by the Food Hygiene Act, the Food Act and the Health Protection Act and the laws on Animal Diseases and Animal welfare in their provinces.

\section{Municipalities}

Most of the practical responsibility for monitoring observance rests with municipal supervisory authorities. The responsible organ on the local level is a committee or other such group, but the local government council can allow this organ to delegate its responsibility to a subordinate official or department. The authorized municipal officials are generally veterinarians and health inspectors. A veterinarian usually serves as the director of an environmental health unit, which is also responsible for local food control. In 1998, there were 270 environmental health units in Finland.

The food control authorities control the enterprises and verify their in-house control on a regular basis. The responsibility of building up an in-house control system covers all food producing enterprises, including the small ones, too. Most of the responsibility for 
inspection lies with municipalities, although the implementation of the system is not yet complete.

\subsubsection{Food Control Organisation}

New central organisation of food control 1.3.2001

In the beginning of March 2001, the National Food Agency and the Department of Food Control of the National Veterinary and Food Research Institute, will be united as a one central authority (called National Food Agency). The new agency will work under the Ministry of Agriculture and Forestry, but still also with the guidance of the Ministry of Social Affairs and Health as well as of the Ministry of Trade. The tasks include risk management and risk communication dealing with all foodstuffs. After this change, the legislative work is done in the ministries and there will be only one central authority for supervising the food control in Finland. At the same time, the Unit of Quality Policy in the Department of Agriculture will be united with the Veterinary and Food Department of the Ministry of Agriculture and Forestry.

Figure 5 visualises the organisation of the Finnish food control system, and in figure 6 the notification system of food borne outbreaks is shown.

At the local level, five provinces and 270 environmental health units in municipalities work in risk management of food. In these municipalities, approximately 1130 persons work with control of food and consumer goods. There are 51 food control laboratories in Finland. Regarding the local control of primary agricultural production, about 25 manpower/year in 15 local Employment and Economic Development Centres used for the inspection work. 


\section{The control from farm to table in Finland}

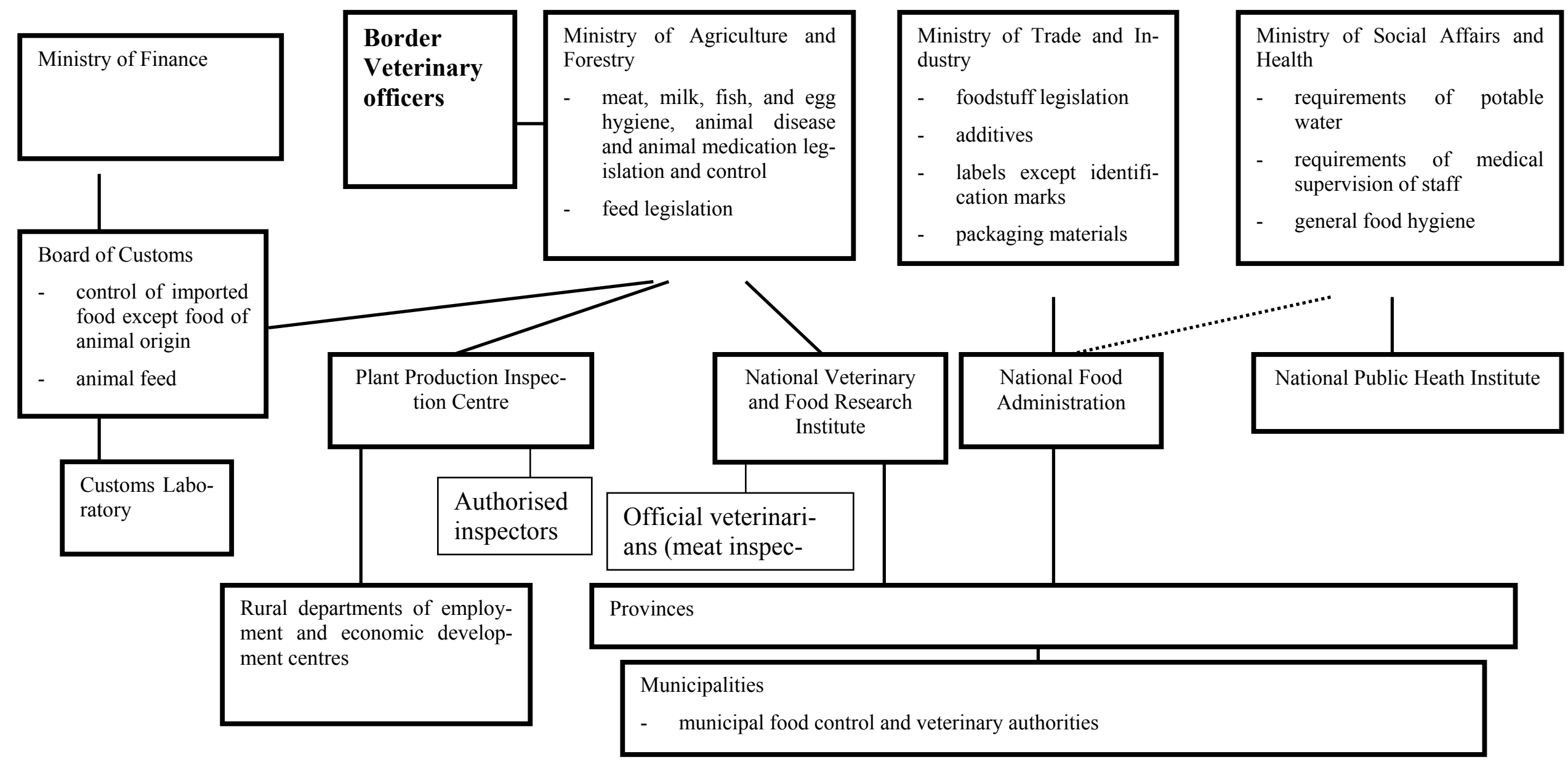

Figure 5. Food control from farm to table in Finland. 


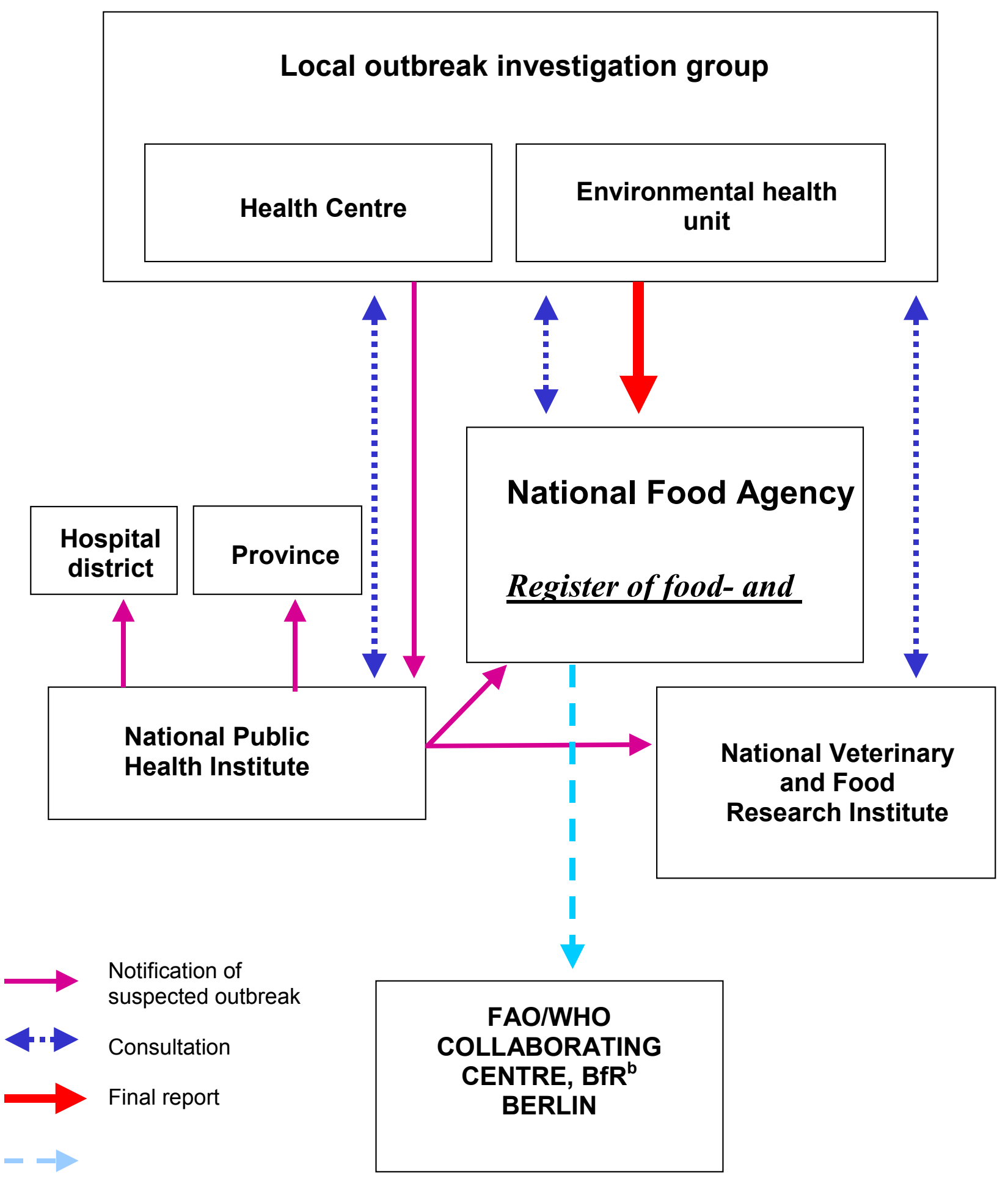

Figure 6. Notification of suspected food borne and waterborne outbreaks, final report and consultation in Finland. 


\subsubsection{Zoonosis Network}

Instead of establishing a zoonosis centre, Finland has a permanent working group for zoonoses since the beginning of year 2000. Because the co-operation between different sectors in risk management is good at the official and non-formal level, creating a special zoonosis centre has not been felt to introduce any benefit to this field. The Ministry of Agriculture and Forestry has nominated to this group the representatives of the Veterinary and Food Department and of the Unit of Quality Policy in the Department of Agriculture (both of the Ministry of Agriculture and Forestry), the Ministry of Social Affairs and Health, the Plant Production Inspection Centre, the National Veterinary and Food Research Institute, the National Food Administration and the National Public Health Institute (see figure 5). This group is responsible e.g. for improving the cooperation, following the zoonosis situation from farm to table, creating a zoonosis strategy of Finland as well as for producing the annual zoonosis report according the zoonosis directive. In addition to this working group, several other groups discuss about specific issues of zoonoses, e.g. groups for listeriosis, VTEC and viruses.

\subsubsection{Co-ordination of activities}

The co-ordination of activities occurs mainly in accordance with the need of co-operation. There is a daily co-operation within the food sector between the National Veterinary and Food Research Institute and National Food Administration. In questions related to safety of animal feeding stuffs or product approval, the Ministry of Agriculture and Forestry/Department of Agriculture and Plant Production Inspection Centre (KTTK) consult experts almost on a daily basis from the National Public Health Institute (NPHI), the National Veterinary and Food Research Institute (EELA), the Agricultural Research Centre (MTT) and the Technical Research Centre (VTT), as well as the Environmental Research Institute (SYKE).

These co-operations are based on practical and product approval issues. However, on the surveillance and reporting system of food- and water-borne outbreaks in Finland, there is an official instruction given by the Ministry of Social Affairs and Health in 1997. The Municipal Health Protection Authority (environmental health unit) bears the main responsibility for conducting the investigation of an outbreak and the reporting thereof. To ensure the co-operation with medical authorities there should be a preexisting outbreak investigation group in every municipality. The group should consist of local veterinary, medical, health protection and food control officials. The notification of a suspected outbreak is sent by the local surveillance group to the National Public Health Institute that will immediately inform the national food control authorities. When the outbreak investigation has been completed, a final report will be sent to the National Food Administration, which will deliver it to National Public Health Institute and National Veterinary and Food Research Institute and compile an annual national report.

To strengthen the co-operation between competent ministries and central authorities a National Management Group on Food and Waterborne outbreaks has been appointed by the Ministry of Social Affairs and Health since 1997. The members come from:

- Ministry of Social Affairs and Health 
- Ministry of Agriculture and Forestry

- National Public Health Institute

- National Food Administration

- National Veterinary and Food Research Institute

\subsubsection{Control and Registration of Imported Food}

At veterinary border inspection stations, border veterinarians employed or authorised by the Ministry of Agriculture and Forestry examine foodstuffs of animal origin coming from non-EU countries. The Finnish Customs Laboratory takes care of the imports not covered by this inspection.

The imported foodstuffs of animal origin from other EU member states are inspected at their first destination, the premises of the firs enterprise that takes delivery of foodstuffs from another EU member state. The enterprises inform the local authorities about receiving a shipment. EELA keeps a national register of these first destination places.

Table 2. The import of certain foodstuffs during 1996-1998 in Finland.

\begin{tabular}{|l|c|c|c|}
\hline Foodstuff & \multicolumn{3}{|c|}{ Import (million kg) } \\
\hline Beef & 1996 & 1997 & 1998 \\
Pork & 7.8 & 8.2 & 11.5 \\
Poultry meat & 13.1 & 10.9 & 12.7 \\
Sheep meat & 2.6 & 2.7 & 2.5 \\
Cheese & 0.9 & 1.1 & 1.0 \\
Wheat & 11.6 & 17.3 & 18.0 \\
Rye & 216.3 & 133.8 & No statistics \\
\hline
\end{tabular}

Table 3. The self-sufficiency of various foodstuffs in Finland (percentage).

\begin{tabular}{|l|c|c|c|}
\hline Foodstuff & $\mathbf{1 9 9 6}$ & $\mathbf{1 9 9 7}$ & $\mathbf{1 9 9 8}$ \\
\hline Milk and milk products & 106 & 109 & 108 \\
Meat & 100 & 103 & 101 \\
Eggs & 125 & 124 & 120 \\
Bread grain & 79 & 74 & 65 \\
Sugar & 75 & 76 & 70 \\
\hline
\end{tabular}


As table three shows, Finland is self-sufficient in eggs, milk, pork and beef. There are overproduction problems especially with eggs and milk fat, however.

\subsubsection{Monitoring/Surveillance of Zoonotic Pathogens}

\subsubsection{Salmonella}

Monitoring of Salmonella is mainly based on animal feeding stuffs, animal and abattoir sampling. Some samples are also taken at the retail level, but not as based on the national monitoring programme. The follow-up of human incidence is based on reporting by physicians and collecting and typing of isolated strains sent by microbiological laboratories.

\section{Feeding stuffs}

The Feeding stuff Act has been applied in Finland to detect Salmonella in the feeding stuffs. The principle of heavy responsibility and obligation to pay damages included in the legislation on feeding stuffs has increased the compliance of feed manufacturers towards abolishing Salmonella.

Salmonella has been controlled in feeding stuffs over 40 years. The manufacturers of feeding stuffs, compound feed and feed additives are subject to continuous monitoring by the KTTK. Samples are taken from the imported feeding stuffs, feeding stuffs available on the market and those that are being prepared according to a control plan, which is revised annually. The frequency of the sampling and analysis is established on the basis of the estimated Salmonella risk of each feeding stuff. The risks are estimated on the basis of long-term control results and the nature and method of transportation of each lot of feeding stuffs.

Feed manufacturers have HACCP-based control systems to eliminate pathogenic agents in the feed manufacturing process. Own check programmes direct the feed manufacturers to take samples during the feed production process and from the premises. KTTK supervises the process by monitoring control systems, approving on voluntary basis own check programmes as well as by taking official samples in the final products.

\section{Animals and food}

Finland became a member of the EU in the beginning of 1995. In the membership negotiations, Finland was granted additional guarantees concerning Salmonella. The additional guarantees were subject to the condition that Finland draws up a national Salmonella control programme, which is approved by the EU Commission. The implementation of the programme started in May 1995. The Finnish Salmonella control programme covers cattle, pigs and poultry as well as meat and eggs obtained from these. Salmonella inspections are carried out on the production farms and in the abattoirs and meat cutting plants.

The Salmonella control of pigs in Finland is based on the inspection of random samples collected at slaughter and in cutting plants. Lymph node and surface swab samples are taken regularly throughout the year at abattoirs, and meat samples taken during the pro- 
process at the cutting plant are also examined. Faecal samples are inspected from boars sold to artificial insemination stations and from pig herds included in the voluntary health control scheme, as well as from all cases where salmonellosis is suspected.

The Salmonella control of cattle works according to the same principles as for pigs. Lymph node, surface swab as well as meat samples are taken regularly by random sampling. Live animals and herds are inspected because of suspicion of salmonellosis. Herds from which bulls are sold to artificial insemination stations are also inspected.

Salmonella control of poultry is primarily based on the control of the production farms and prevention of salmonellosis. The control of the primary production and regular examination of samples is particularly important in the case of poultry because the infections are usually not revealed as sick animals. Samples of the faeces of broilers, turkeys and layers are examined at all the production stages, and hatcheries are also inspected and sampled regularly. Efforts are made to detect Salmonella at an early stage, before the slaughter of the broilers or turkeys, or at the beginning of laying, which is an efficient way of preventing eggs or meat contaminated by Salmonella from reaching the consumer. In poultry meat cutting plant samples taken during the production process are also examined regularly. The control covers hens, broilers, turkeys, guinea fowl, ducks and geese.

The ISO 6579:1993 method and NMKL method No. 71:1991 have been approved for use in the National Salmonella control programme as provided for the Com-mission Decision 97/278/EC.

Detection of Salmonella on a farm or in a food production factory always leads to legislated measures being taken, including epidemiological investigations, restrictions on the sale or purchase of animals and on the use of products contaminated by Salmonella, disinfection procedures as well as special arrangements in the slaughtering of animals. The production farms are freed from the restrictions only after it has been established that there is no longer Salmonella on the farm.

The objective of the control programme is to keep the incidence of Salmonella in the production animals and meat and eggs obtained from these, at the level of no more than $1 \%$ throughout the country. The objective of abattoirs or cutting plants is to keep the incidence below $5 \%$.

In addition to the National Salmonella control programme, the industry takes ten thousands of samples from various sources.

\subsubsection{Others}

No other zoonoses are monitored in feeding stuffs (BSE is not regarded as a zoonosis here). Some samples are taken at the retail level, but mainly as part of special projects and not as based on the national monitoring programme (e.g. Campylobacter, Listeria). Physicians and laboratories (EHEC, Listeria monocytogenes), base the follow-up of human incidence on reporting by microbiological laboratories (Campylobacter, Salmonella) or.

Other surveillance programmes for zoonoses, which may transmitted via food, include trichinellosis, brucellosis and tuberculosis. All potential Trichinella hosts, which are slaughtered, are examined for trichinellosis. Each year trichinellosis is found on some pig farms. 
The European Commission has granted Finland the status of a disease-free country for brucellosis in cattle, sheep and goats (B. abortus, B. melitensis). Maintaining this status requires the inspection of all suspected cases of brucellosis and the annual serological mapping of blood samples of sheep, goats and cattle and samples of the tank milk of cows. All calves intended to be used for artificial insemination are also inspected. In 1995-1997 the tank milk of about $10 \%$ of the dairy herds was inspected by the ELISAmethod. Brucellosis in beef animals has been monitored by studying individual blood samples taken at abattoirs, and blood samples have also been collected from goat and sheep farms.

The European Commission has granted Finland the status of a disease-free country for bovine tuberculosis. Today bovine animals are examined for bovine tuberculosis in connection with the control programme for artificial insemination and import and export of animals. In practice, however, the most important method in combating tuberculosis in Finland is the inspection of the carcass and organs of slaughtered animals at the meat inspection. Deer farms selling live animals or producing meat are inspected regularly on the basis of a special health control programme.

\subsubsection{Monitoring/Surveillance of Anti-microbial Resistance}

The anti-microbial resistance patterns of Salmonella strains isolated from animals have been followed since 1983. This follow-up has been spread to cover the whole country and also for other important pathogens and some indicator organisms. The results were collected into the "Bacterial resistance to Anti-microbial Agents in Finland, FINRES" report, published in 1999. In this report, both the human and animal situation is revealed as well as the use of anti-microbials as feed additives, animal and human drugs.

\subsubsection{Risk Assessment Activities}

All the competent authorities mentioned in section 6.2.1., and some representatives from the industry have been working in co-operation in the working group, which made Finnish risk assessment model for Listeria monocytogenes in ready-to-eat-fish (Scientific operation of EU- Task 2.3 -microbiological risk assessment)

The risk caused by the foodstuffs covered by the National Salmonella Control Programme (beef, pork, poultry meat and eggs) is currently assessed at the National Veterinary and Food Research Institute. The first models have been made and after the additional data collection with collaborators, the full risk assessment is expected to be finished in 2001.

\subsubsection{Strengths and Weaknesses in the Finnish System}

\subsubsection{Strengths}

- formal and non-formal co-operation easy both in Finland and at the Nordic level

- whole farm to table chain has the same goal, as intended in the National Quality program

- the useful data for risk assessment purposes will be collected for Quality Data Bank in framework of the National Food Quality Strategy 
- the relatively small number of people involved in food safety helps the collaboration in risk assessment, risk management as well as in risk communication

- After decades of work, the levels of microbiological hazards are low. Therefore the cost for managing these risks are relatively small compared to more severe situation

- the recent development in improving risk communication have increased the level of collaboration

- the industry is willing to co-operate with the authorities in most of the cases, since the high quality (including food safety) is regarded as an essential element of competitive domestic food production

- the data collection is improved in order to facilitate the use for risk assessment purposes

- data concerning zoonoses and anti-microbials have been collected and published (Zoonoses in Finland 1995-1997, 1995-1999 in press, FINRESS 1999)

- good knowledge of dietary information

\subsubsection{Weaknesses:}

- rapid changes of production systems and increasing international trade of feed and food as well fast changes in eating habits by consumers can cause new situations and problems

- data existing on the primary production level should be processed further

- the data at the retail level is mainly collected and stored within each municipality, not at the national level

- not optimal resources for collecting data necessary for risk assessment

- the resources for surveillance at the retail level are not always well planned and prioritised

- the risk management process is not always based on formal risk assessment

- there is not a clear distinction between risk assessment and risk management. However, this work is now in the progress and will probably be solved within one to two years. 


\section{$2.3 \quad$ Iceland}

\subsubsection{Overall National Policy}

The national policy for the surveillance and prevention of food borne diseases has evolved through the cases that the competent authorities have dealt with over the years. It is also fair to say that the activities in this field in the other Nordic countries influence the policy making to some extent. The foundation for the national policy is laid in the Act on foodstuffs from 1995, as well as legislation on hygiene and communicable diseases. The current policy is greatly influenced by the campaign against Salmonella and Campylobacter that has been ongoing for more than a decade.

The most important foundation for the national policy is the $3^{\text {rd }}$ paragraph in the act on foodstuffs: "The production and distribution of foodstuffs shall be conducted in a manner which does not threat the health of the consumers..." On these grounds, the presence of Salmonella and Campylobacter in raw meat and poultry have been considered health threats that have to be reduced significantly or, if possible, eradicated.

A control programme towards limiting public exposure to Salmonella via poultry was initiated in the early nineties. The control programme includes sampling in the chicken houses and at the end of the process line in the abattoirs. In the beginning flocks or production lots positive for Salmonella enteriditis or S. typhimurium were discarded. Flocks or production lots positive for other serotypes were either heat treated or discarded. Later on the producers and the official authorities reached an agreement to discard all Salmonella positive flocks. In addition to this all poultry product shall be labelled with direction on hygienic handling and proper heat treatment. A special program to limit public exposure to Salmonella from an Icelandic speciality; sheep heads, was initiated in '95. It consists of compulsory washing of sheep heads before distribution, as well as labelling similar to that on poultry.

In 1999 the incidence rate for Campylobacteriosis reached 160 per 100.000 inhabitants in Iceland. Evidence pointed to poultry as the main culprit. The Salmonella control program for poultry was expanded to Campylobacter in January 2000. Flocks found positive in sampling approximately a week before slaughtering could only be marketed in a frozen state. In May 2000, an agreement was made between the poultry industry and the competent authorities to freeze all poultry from chicken houses that had Campylobacter positive samples taken prior to- or at slaughter. Products from these houses can only be marketed fresh after two consecutive lots have been produced with all samples negative for Campylobacter.

\subsubsection{Food Safety Legislation}

Act No 93/1995 on foodstuffs is the main act in the foodstuffs field. Its objective is to ensure quality, safety and wholesomeness of foodstuffs and that labelling and other information about them are correct and sufficient. It specifies the responsibilities and the structure for foodstuff control. Furthermore, it defines foodstuffs as any product intended for human consumption, including drinking water. 
Act No 19/1997 on communicable diseases applies mainly to prevention and necessary reaction to communicable diseases. It describes the role and duties of citizens, medical doctors, health care workers, public health inspectors, public health boards and veterinarians. The chief medical officer is responsible for the enforcement of this legislation and has employed the state epidemiologist for that purpose. The state epidemiologist maintains a record of communicable diseases, has access to public and private data relevant to research of communicable disease and is empowered to intervene where there is an imminent threat of an epidemic. This act establishes a consultation committee on communicable diseases with 7 members.

Act No 7/1998 on Hygiene and Environment Protection has the objective to ensure wholesome environmental conditions for the citizens and to protect the quality of wholesome and unpolluted environment. It establishes the Environmental and Food Agency as well as the local food control structure.

Other relevant acts are Act No 66/1998 on veterinary health control, Act No 96/1997 on meat, and Act No 25/1993 on animal diseases and prevention. This legislation describes the veterinary control of domestic and imported products, as well various measures to prevent the spread of animal diseases.

\subsubsection{Overall Structure}

There are 3 ministries responsible for food control in Iceland. Ministry of Fisheries has established the Directorate of Fisheries for the enforcement of the laws regarding the handling and inspection of marine products. Ministry of Agriculture provides for the veterinary services and has feed control established at the Agricultural Research Institute. The Chief Veterinary Officer is in charge of the veterinary services and has District Veterinary Officers employed for control activities at the farm level and in slaughterhouses. Ministry for the Environment is ultimately responsible for the food control in Iceland. The Environmental and Food Agency co-ordinates the activities of the Local Food Control Authorities, which are run by the municipalities. Among the roles of these bodies is food control, water quality and import control of non-animal foodstuffs.

Ministry of Health and Social Security has mainly two subsidiary bodies established for surveillance and prevention of food- and waterborne diseases. At the Directorate of Health, the state epidemiologist has recently been employed. His role is to supervise the prevention and control of communicable disease. The Laboratory at the University Hospital receives the majority of the faecal samples taken in Iceland and manages the epidemiological information concerning food borne gastro-enteritis. 


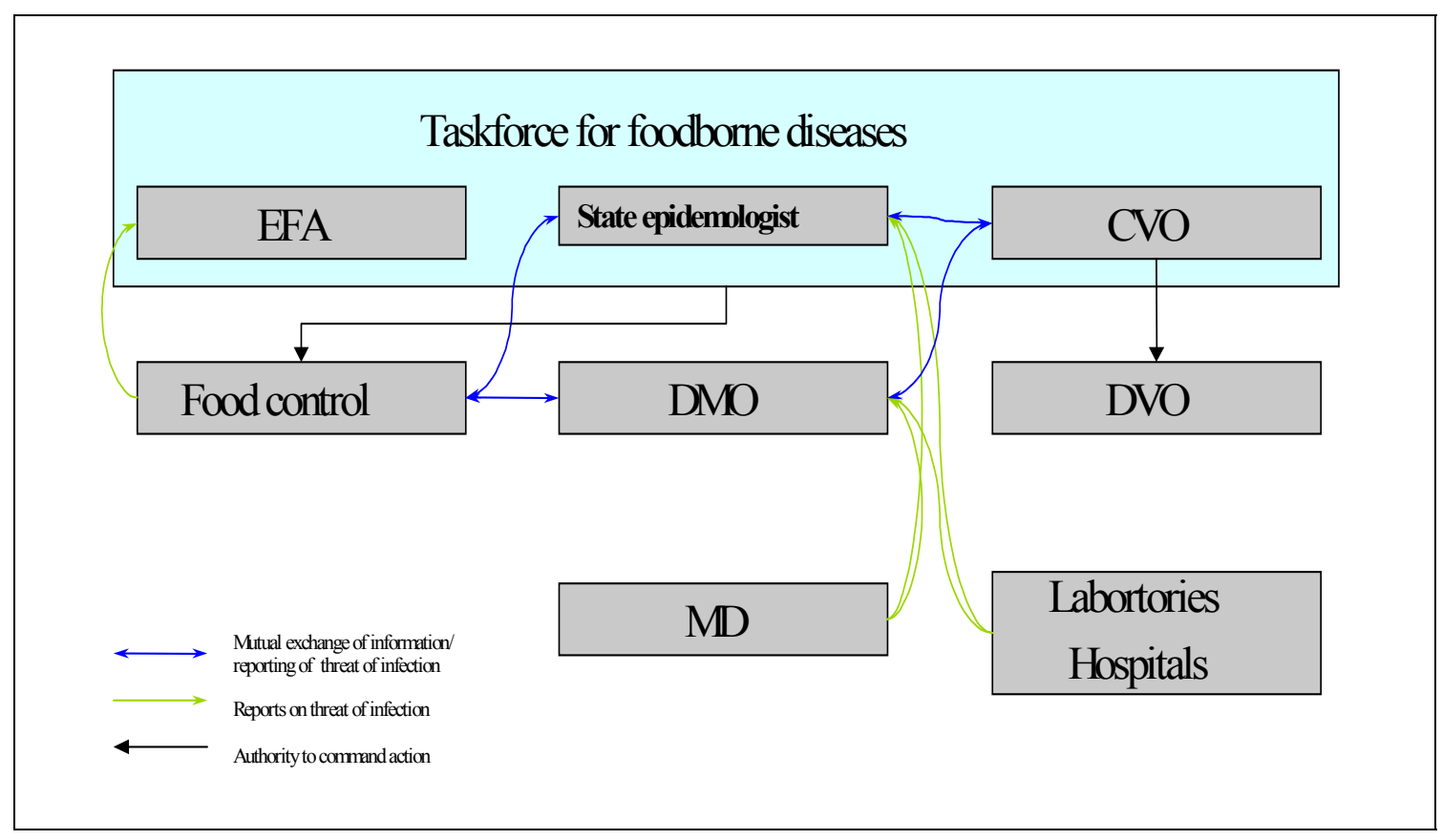

Figure 7. The structure of authorities involved in prevention and action against food borne diseases. Abbreviations: EFA: Environmental and Food Agency of Iceland, CVO: Chief Veterinary Officer, DMO: District Medical Officer, DVO: District Veterinary Officer and MD: Medical Doctor.

\subsubsection{Zoonosis Network}

A formal zoonosis network has not been established in Iceland nor a central database on zoonotic diseases. In 1999, however, a committee with representatives from authorities and laboratories working through the whole farm to table continuum was established to serve as a forum for the exchange of data, experience and views on food borne diseases and co-ordination of data collection and intervention activities. Other zoonotic infections than food borne are not within this committees mandate. These would either be dealt with in a consultation committee on communicable diseases and/or by the Chief Veterinary Officer.

\subsubsection{Control and Registration of Imported Food}

Import control for foods to Iceland is divided between three ministries in the same way as other food control. All legal import of foods is registered within a database maintained by the customs control. EFA has online access to this database. All notifications through RASFF are run through the database to find out if the corresponding products have been imported.

Import control for foodstuffs of animal origin, other than fish, is within the CVO's competence. The imported foods have to fulfil the same criteria as any domestic foods, i.e.: Milk and milk products shall be pasteurised or made from pasteurised milk, animals may not be treated with hormones or other growth promoting agents and Salmonella guarantee must accompany all meats. 


\subsubsection{Monitoring/Surveillance of Zoonotic Pathogens}

\subsubsection{Salmonella}

A control programme for Salmonella in poultry has already been described in this chapter.

\subsubsection{Others}

A control programme for Campylobacter in poultry has already been described in this chapter.

\subsubsection{Monitoring/Surveillance of Anti-microbial Resistance}

All human isolates of Salmonella and Campylobacter are tested for resistance to various antibiotics. No routine testing for isolates from foods or animals has been implemented.

\subsubsection{Risk Assessment Activities}

Risk assessment for Campylobacter in poultry is already being undertaken in cooperation between EFA, CVO, University Hospital, Keldur Pathology Research Station and Icelandic Fisheries Laboratories.

\subsubsection{Strengths and Weaknesses of the Icelandic System}

\subsubsection{Strengths}

- Relatively few persons are involved in risk assessment and management, which makes communication more rapid and effective.

- The size of the food distribution system and good registration at various stages makes tracing of products possible.

\subsubsection{Weaknesses}

- Monitoring and surveillance activities have been neglected in many areas. 


\section{$2.4 \quad$ Norway}

\subsubsection{Overall National Policy}

\subsubsection{Introduction}

The main objective in Norwegian food safety policy is to ensure that food products on the Norwegian market are safe, i.e. free from infectious agents and foreign compounds in concentrations that may pose a risk to the health. The authorities possess a number of means to fulfil this aim including legislation, enforcement, monitoring and surveillance activities, information service, educational work, and research.

The food safety policy is part of the work promoting health and is therefore part of the health policy. However, it is important to view the food safety policy in close connection to animal health policy, agricultural, fishery and environmental policy, trade and consumer policy, as well as educational and research policy. It is also an aim to strengthen consumer influence on the food policies.

\subsubsection{From farm to table}

Norway has a tradition of addressing foodborne health hazards with a perspective encompassing all steps from farm to table. The official control systems are structured in such a way that preventive measures can be carried out as close to the source as possible. Thus, efficient preventive effort against many foodborne zoonotic bacteria can be implemented already in the primary production. However, it is recognized that health hazards can be introduced throughout the food chain. Therefore, the growth and dispersal of pathogens must also be prevented through the successive steps of production, processing, distribution, and retail.

The authorities' efforts to ensure food safety is carried out as a collaboration between three ministries The Norwegian food safety legislation is laid down by the Ministry of Health and Social Affairs, the Ministry of Agriculture, and the Ministry of Fisheries. The legislative tools cover the entire chain from farm to table.

It is pointed out that the producer bears the responsibility that the food does not pose a risk to human health. In recent years, a HACCP-like concept has been introduced in Norwegian food establishments. This is believed to improve food safety by increasing knowledge among the producers and putting more responsibility upon them. The establishments are required to have in place an own-check programme, of which the authorities regularly review the conduct and results. Thus, the main preventive efforts lie in the prevention in the primary production and in the HACCP-based surveillance in the successive steps.

\subsubsection{Risk analysis as a tool}

In Norway, the importance of separating risk assessment from risk management is emphasised. However, it is recognized that a dynamic interaction between risk assessors and risk mangers is important for having a constructive, transparent, and cost-effective risk analysis process.

Health risk assessments are conducted in independent scientific institutions (see below) and in SNT's Scientific Committee. This committee is an independent body whose 
mandate is to give scientific advice in food safety matters. Specific health risks are assessed, and the committee also gives its opinion on strategies and priorities important to food safety, especially in relation to monitoring, surveillance, and research. The committee enables a systematic dialogue between the scientific community and the administration.

Risk management activities are mainly conducted in the relevant directorates (see below.) or at the local level. Risk management options assessments are based upon risk assessment outcomes, taking into account political and sosio-economic factors, consumer perception and other relevant factors. Major decisions is the responsibility of the relevant ministry, otherwise the responsibility lies with SNT, the SDT, the LT, or at the local level.

Norwegian authorities apply the precautionary principle when scientific uncertainty or lack of data/knowledge makes a comprehensive risk assessment impossible. There is a legal basis in the existing rules for restrictions on foodstuffs when adverse health effects are suspected.

Norwegian authorities acknowledge the importance of and practise full openness and transparency in their decision-making processes, including risk management. While information dominated the contact with the public in earlier years, today's contact between the authorities and stakeholder groups to a larger extent is in the form of communication - a dialogue. Improved risk communication is currently a prioritised area within Norwegian food safety policy.

\subsubsection{Norway's Salmonella control programmes}

Norway has achieved an efficient control of Salmonella in the domestic food production chain. Monitoring of Salmonella in animal feed, live animals, and food has been carried out in Norway for many years, and stringent measures have been taken whenever a case has been detected. Any finding of Salmonella in animals, humans, feed, or food is compulsory notifiable. Norway's control strategy for salmonella is a good example of a policy encompassing the whole food chain from farm to table and where preventive efforts are implemented as close to the source as possible.

From 1962 through 1998, Norway practiced a restrictive import policy in regard to live animals and food and feed of animal origin. Since January 1, 1999 Norway has been part of the EU's internal market also on the veterinary sector through revision of the EEA-agreement. The EU has acknowledged Norway's favourable Salmonella situation. Similarly to Sweden and Finland, Norway can require additional guarantees in regard to Salmonella when importing live animals and feed and food products of animal origin from the EU.

Nation-wide official Norwegian Salmonella Control Programmes for Live Animals, Eggs, and Meat was launched in 1995. These programmes, that are EU-approved, cover both live animals (cattle, swine, and poultry) and meat products (cattle, swine, sheep, and poultry). The aim is to provide reliable documentation on Salmonella prevalence in the animal food production, and to detect any increased occurrence of Salmonella infections among food production animals in Norway. The Norwegian Salmonella Control Programmes have documented that so far live cattle, swine, and poultry in Norway as well as domestically produced food products of animal origin are virtually free from Salmonella sp. The surveillance data indicate that the overall prevalence is below $0.1 \%$. 
There are also official surveillance programmes for Salmonella in relation to animal feed. Furthermore, various surveys and studies as well as diagnostic work and epidemiological investigations provide additional epidemiological information.

If Salmonella is detected in livestock, feed or foodstuffs, the resulting initiatives aim at finding, isolating, and destroying the source. Relevant epidemiological investigations will be initiated in order to find and eliminate the source of the infection or contamination. Action is taken to prevent spread of the bacteria. Action includes restrictions on animal movement that are put on farms and not lifted before the infection has been eliminated. Poultry flocks infected with invasive serovars will be destroyed. Meat and poultry meat contaminated with Salmonella will be destroyed.

For more details about the salmonella surveillance in Norway, please see section 6.4.6.1.

\subsubsection{Food Safety Legislation}

Food safety legislation is laid down by the Ministry of Health and Social Affairs, the Ministry of Agriculture, and the Ministry of Fisheries. These ministries administrate the following acts related to food safety: The Food Control Act, the Act on the Coordination of Food Control, the Meat Production Act, and the Quality Control Act of Fish and Fishery Products.

The Meat Production Act (Ministry of Agriculture) gives the food control authorities the opportunity to investigate and take samples in animal herds when the aim is to safeguard the foodstuffs. The act regulates the handling of animals for slaughter and the slaughtering process, and is central in connection to the prevention of zoonoses.

The four acts on foodstuffs are mainly framework laws. Most of the connected regulations and guidelines are based on the EEA agreement, and aim at promoting demands on health, quality, and integrity through decisions on hygiene, contents and labelling. In accordance with the EEA agreement, Norwegian legislation is harmonised with EU law and Norway is recognised as a part of the internal market. Possible health implications due to dietary patterns or other specific national conditions are assessed prior to implementation. Amendments considered necessary from a health point of view may be negotiated within the framework of the EEA agreement. In connection to Salmonella sp. Norway has the right to demand that imported meat, eggs and live animals must originate from producers who have been subdued to a control as strict and thorough as the control carried out within Norway.

A rationalization of the legislation has been proposed through the restructuring of the four existing laws into one Foodstuff Act. Because the food safety sector in Norway professionally is managed by three Ministries with different surveillance authorities, there is an on-going process on developing a simpler and less complex system. In 1994 a committee was established to consider the possibilities for simplifying food laws, and how to achieve a more effective food control (NOU 1996). White Paper No 40 (199697) underlines the importance of food control being considered in a fiord/stable to table perspective. A later report (Department of AdministrativeAffairs), has stressed the importance of separating health and industrial interests. A discussion is still taking place as to which considerations shall be emphasised when creating a new legal basis for the field of food safety. No final decision has been made. 


\subsubsection{Overall structure}

\subsubsection{Organization and description of institutions involved}

\section{Ministries}

The risk management from farm to table in Norway lies within the auspices of three ministries; the Ministry of Health and Social Affairs (SHD), the Ministry of Agriculture (LD), and the Ministry of Fisheries (FID). If the present organization is the most optimal one is currently being evaluated.

\section{Directorates}

\section{The Norwegian Food Control Authority (SNT)}

SNT administrates the foodstuff legislation, consisting of five laws and approximately 100 guidelines on the production and sale of foodstuffs, and quality demands for foodstuffs and drinking water. As the foodstuff legislation involves all the three ministries mentioned above, SNT is linked to all these ministries. However, LD is SNT's administrative ministry. SNT has approximately 110 employees.

SNT has the responsibility for the control and inspection of all abattoirs, food businesses that produce foodstuffs of animal origin, as well as manufacturers, wholesalers, packing departments, and wholesale warehouses that turn over more than 20 million NOK a year. Furthermore, the SNT has the responsibility for the control of imported foodstuffs, including meat. SNT delegates control tasks at the local level to the $82 \mathrm{mu}$ nicipal food control authorities in Norway. Sixteen border-control stations are responsible for control of imported food of animal origin from third countries (please see Control and Registration of Imported Food, section 6.4.5).

Each year SNT initiates and funds several surveys regarding specific foodborne pathogens and specific food products.

SNT is connected to a scientific committee and a council. The scientific committee represents the superior scientific competence within the domain of SNT. This scientifically based committee is part of the foundation for SNT's services. 28 experts from central scientific institutions form the SNT Scientific Committee.

\section{Municipal Food Control Authorities (KNT)}

All practical enforcement of food control legislation is carried out at the local level. KNT conducts all inspections and represent a first point of contact for consumers and foodstuff manufacturers. The Food Control Act, mentioned below, stipulates that all municipalities must carry out food control activities. Today, Norway has 82 KNT. These authorities supervise the production, imports, sale and marketing of foods and the monitoring of foreign substances in food and control more than 30.000 Norwegian enterprises. Local decisions are the responsibility of KNT or appropriate municipal body. Any appeal may be directed to SNT, the municipal executive board, or the office of the county governor. 


\section{The Norwegian Animal Health Authority (SDT)}

SDT reports to the Ministry of Agriculture.

SDT has approx. 320 employees in three administrative levels, and is in addition administratively responsible for the local animal welfare boards: 193 District Veterinary Officers; 225 animal welfare boards, 9 Regional Veterinary Officers with approx. 62 employees; the RVO is accountable for the service on the local level, and the Central Unit with 37 employees.

In 2001 SDT has a budget of approx. 232,3 mill NKR (29.036.000 ECU).

SDT is the competent authority for the Animal Disease Act, Fish Disease Act, Animal Welfare Act, and the Veterinary Surgeons Act.

The principal duties are related to inspection and documentation of animal health, animal disease control, animal health regulations related to international trade, animal health schemes in cooperation with the industry, animal welfare, advisory service on proper use of medicinal products for animals, efforts to promote wholesome foodstuff from farmed animals, and administration of the local veterinary services in provision of emergency assistance.

Internationally the Central Unit of SDT will be the receiver of reports on animal diseases and animal welfare. Likewise, the Central Unit will supply other countries with similar information from Norway.

\section{The Directorate of Fisheries (FD)}

The Ministry of Fisheries is responsible for the FD. The Quality Control Service of the FD with five district offices and 32 local offices carries out control of fish and fish products for export. Control of products produced for the domestic market, however, is the responsibility of the local food control authorities.

The local offices are placed along the coastline near the most important landing and production sites for fish. These locations ensure an ongoing control of the hygiene and quality on the fishing vessels.

\section{The Norwegian Agriculture Inspection Service (LT)}

LT is a directorate under the Ministry of Agriculture that administers, among others, the legal framework for import, distribution and use of feed for terrestrial animals (SDT is responsible for the enforcement in regard to imported feed of animal origin). The main objective of this legislation is to ensure that feed do not represent a hazard for animals, humans, or the environment. The legislation in regard to feed safety is harmonised with the EU.

There are specific requirements in regard to salmonella control (official surveillance, internal control). Every finding of salmonella must be reported to LT. LT can stop the distribution of feed if it considers that particular products represent an unacceptable risk to human- or animal health.

There are reporting routines in place between SDT and LT. LT collects all data on salmonella in regard to feed and submits these to the Norwegian Zoonosis Centre. 
LT has a staff of about 140 employees.

\section{The Norwegian Board of Health}

The Norwegian Board of Health is referring to the Ministry of Health and Social Affars. In each of the 19 counties in Norway there is a County Medical Officer representing the central health authorities. In the municipalities, the municipal medical officers have responsibilities according to the law regarding communicable diseases.

The Norwegian Board of Health activities in regard to the zoonotic diseases are in principle not different from its activities in regard to other communicable diseases. Theses activities are based on the Communicable Diseases Control Act from 1994. According to the act, §7-1, "The Norwegian Board of Health shall have general responsibility for supervising that municipal, county, and central government activities are in accordance with this act and within regulations or individual decisions pursuant to this Act. By means of advice, guidance, information and decisions pursuant to this Act, the Norwegian Board of Health shall help to meet the needs of the population for services and measures in connection with communicable diseases.

\section{Scientific institutions}

\section{National Institute of Public Health (NIPH)}

NIPH is organized under the Ministry of Health and Social Affairs. NIPH employed 450 persons by January 2000. One of its main objectives is to prevent and control infectious diseases.For foodborne zoonoses and zoonotic bacteria, this is achieved through:

- Surveillance of foodborne and enteric diseases through The Norwegian Surveillance System for Infectious Diseases (MSIS).

- National reference laboratories, including the National Reference Laboratory for Salmonella.

- Phenotypic and genotypic characterisation of pathogens from the whole food chain, including antimicrobial resistance and DNA-fingerprinting.

- Detection and investigation of disease outbreaks in co-operation with local and national authorities.

- Identification of risk factors for disease through analytic epidemiological research.

- Research projects in molecular epidemiology, population genetics and antimicrobial resistance.

- Information, recommendations and advice to national and international authorities, and to the public.

The National Notification System for Infectious Diseases (MSIS) is a nation-wide system for continuous registration, analysis and reporting of the status and trends concerning infectious diseases. Data from the MSIS is the basis for outbreak detection, assessment of preventive and control measures, epidemiological research, and formulation of 
priorities and preventive strategies. MSIS distinguishes between indigenous and imported cases.

According to the Communicable Diseases Control Act, all microbiological laboratories analysing specimens from humans as well as all physicians are required to notify cases of specified diseases to the central unit of MSIS.

Information from the surveillance system is published weekly, monthly and annually. The total numbers of cases as well as the numbers of indigenous and imported cases in each municipality, each county and in the whole country, are given.

\section{National Veterinary Institute (VI)}

VI is the Ministry of Agriculture's official scientific institution for veterinary research, diagnostic, analytic and other support services. VI provides scientific support and expertise to the Ministry of Agriculture, and the three directorates SDT, SNT, and LT. VI consist of the main laboratory in Oslo with three scientific departments (Food and feed hygiene, Animal health, Fish health), and five regional laboratories; Sandnes, Bergen Trondhjem, Tromsø, and Harstad. The Norwegian Zoonosis Centre is a satelite institution under VI in collaboration with the NIPH. VI employs in total approximately 270 persons, 120 of whom are scientific personnel.

The activities at VI are in the areas of animal health, fish health, and food and feed safety in Norway. VI conducts research and diagnostic/analytical work and runs various surveillance programs. It is a national referance laboratory for several agents and methods. Moreover, VI gives scientific advices and conducts risk assessments.

Through the research, diagnostic and reference functions, developmental activities, participation in surveillance programs and consultations, VI is a major contributor to the formulation and implementation of Norwegian agriculture and food policies.

\section{Norwegian Zoonosis Centre (NZ)}

The Norwegian Zoonosis Centre was established in 1999. It is organized within VI, but is a collaboration with the NIPH. The main objective of the NZ is to collect, analyse and present epidemiological data on zoonoses and zoonotic agents in Norway as a basis to prevent the spread of zoonoses through food, feed, animal and animal products. NZ coordinates surveillance and monitoring regarding zoonoses, and is responsible for the required reporting to the European Surveillance Authority as laid down in the EU's Zoonosis directive. Furthermore, the NZ is responsible for coordinating the establishment of a monitoring program regarding antimicrobial resistance in bacteria from animals and foods, which is to be linked to a similar program in human medicine. NZ also initiates relevant research projects. Activities aimed at informing the public and various stakeholders about zoonoses are emphasized, and the NZ arranges regular open seminars on important issues. 


\section{Norwegian Crop Research Institute}

The Norwegian Crop Research institute is a partner for all parties in Norwegian agriculture and horticulture. The institute receives income from a number of sources, the two main ones being the Ministry of Agriculture and The Research Council of Norway. The institute aims to strengthen research in development of environmentally sound farming and ecological agriculture.

Figure 8 shows Norwegian risk management of zoonotic bacteria from farm to table as described in section 6.4.3.1. 
Figure 8. Risk management of zoonotic bacteria from farm to table in Norway.

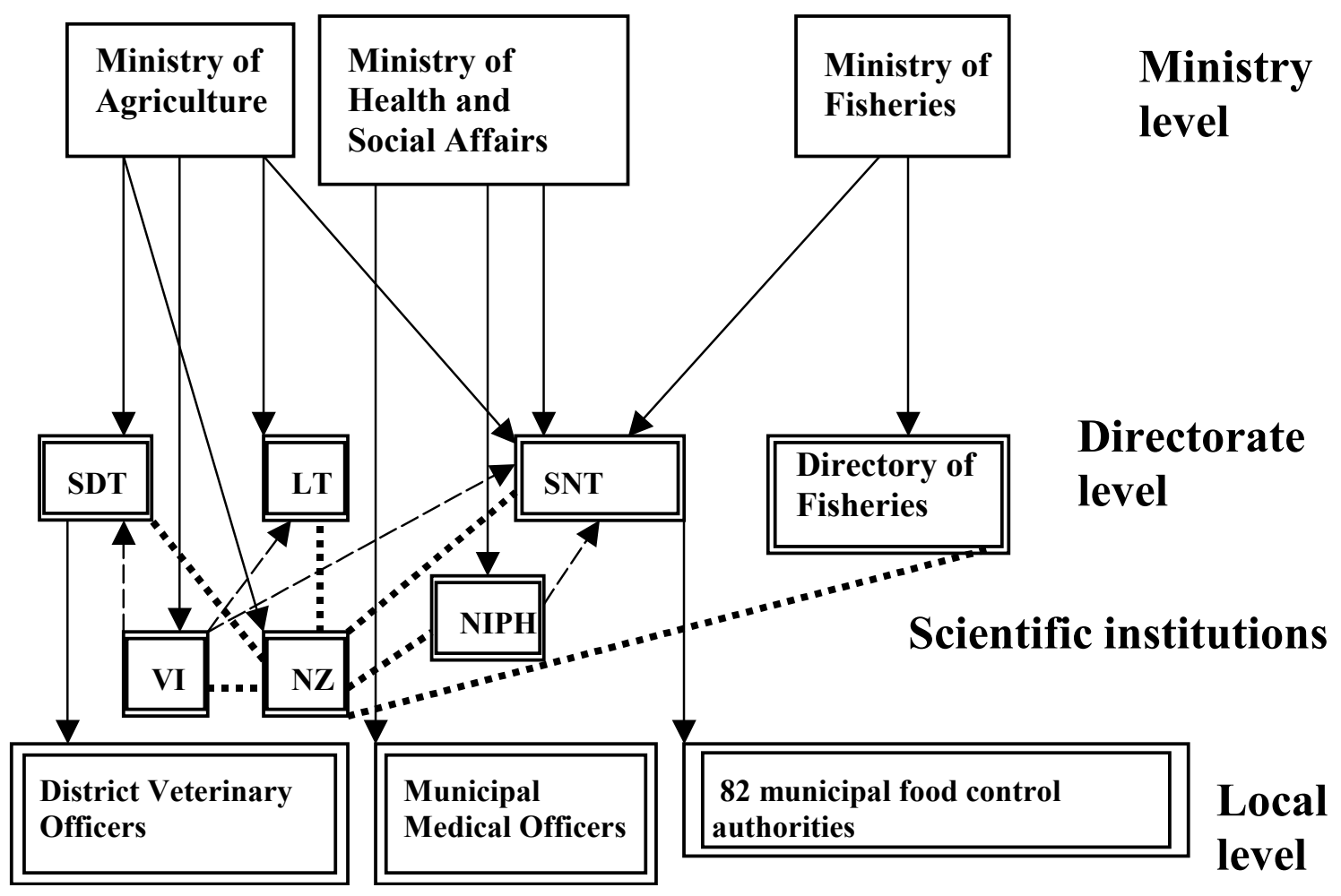

Administrative links

- - - - - Scientific advices

Data flow

Table 4. The budget development from 1990 to 1996 (exc. construction work)

\begin{tabular}{|l|c|c|c|c|}
\hline Institution & $\begin{array}{c}\mathbf{1 9 9 0} \\
\text { (mill NOK) }\end{array}$ & $\begin{array}{c}\mathbf{1 9 9 6} \\
\text { (mill NOK) }\end{array}$ & Increase 1990-96 & $\begin{array}{c}\text { Increase } \\
(\mathbf{\%})\end{array}$ \\
\hline SNT & 30.3 & 45.2 & 14.9 & 49 \\
SDT & 50.2 & 130.8 & 80.6 & 161 \\
VI & 42.1 & 70.1 & 28.4 & 68 \\
SLT & 44.7 & 51.9 & 7.2 & 16 \\
Crop Re- & 97.5 & 100.3 & 2.8 & 3 \\
search & & & & $\mathbf{6 7}$ \\
\hline TOTAL & $\mathbf{2 3 8 . 1}$ & $\mathbf{3 9 8 . 7}$ & $\mathbf{1 6 0 . 6}$ & \\
\hline
\end{tabular}

The budget development in the five institutions, dealing with various aspects of food production from farm to table, gives an indication of the government's priorities in the nineties. Thus, the budget for these institutions has risen from 3 to 161 percent during 
the years from 1990 to 1996 (table 4), which illustrates the increased emphasis put on food safety issues in recent years.

Annually 10 to 12 million NOK is used by the state to SNT for programmes on contagious agents. Furthermore, Norwegian Animal Health Authority receives means for programmes concerning animal health.

\subsubsection{Notification systems}

\section{Surveillance system for communicable diseases}

The National Notification System for Infectious Diseases (MSIS) at the NIPH is a nation-wide system for continuous registration, analysis and reporting of the status and trends concerning infectious diseases. Data from the MSIS is the basis for outbreak detection, assessment of preventive and control measures, epidemiological research, and formulation of priorities and preventive strategies. MSIS distinguishes between indigenous and imported cases.

According to the Communicable Diseases Control Act, all microbiological laboratories analysing specimens from humans as well as all physicians are required to notify cases of specified diseases to the central unit of MSIS.

Information from the surveillance system is published weekly, monthly and annually. The total numbers of cases as well as the numbers of indigenous and imported cases in each municipality, each county and in the whole country, are given.

The specificity of the surveillance system is high. On the other hand, the sensitivity of the surveillance system is probably much lower as several factors influence the proportion of cases that are notified.

\section{Notification system for food-associated diseases}

The Norwegian Food Control Authority has since 1988 administered a voluntary notification system for food-associated illnesses. This system focuses on the implicated food rather than the patients. The Municipal Food Control Authorities collects results from epidemiological investigations as well as information received from the community population and, as far as possible, elucidate the causes of foodborne diseases. Incidents of sporadic disease and outbreaks of foodborne disease together with information about the contamination of the foodstuff (what went wrong) are reported to the Norwegian Food Control Authority. Annually, a total of $100-250$ incidents of foodborne disease (outbreaks and sporadic cases) are reported in this system. However, only $15-40$ of these incidents are laboratory confirmed as food or waterborne. Most reported incidents involve outbreaks caused by non-zoonotic agents such as Bacillus cereus, Staphylococcus aureus and Clostridium perfringens. The notification system for food-associated illnesses is hampered by insufficient reporting, and only reveals the tip of the iceberg. Still, valuable information is collected which serves as useful input to food control and information strategies.

\subsubsection{Zoonosis Network}

The Ministry of Agriculture is responsible for the SDT, the LT, the VI, and the Norwegian Zoonosis Centre. Furthermore, the Ministry of Agriculture has the administrative responsibility for SNT. Thus, most of the activities and responsibilities in relation to 
risk management of foodborne zoonotic bacteria lie under the auspices of the Ministry of Agriculture. However, the Ministry of Health and Social Affairs is responsible for, through the NIPH, the surveillance of communicable diseases in the human population, and, through the Norwegian Board of Health, to implement preventive measures in the human health sector.

In order to coordinate activities in regard to zoonoses and zoonotic agents, the Government in 1999 established a Zoonosis Centre (see section 6.4.3). The Norwegian Zoonosis Centre is organized in collaboration between the VI and NIPH in order to ensure that the whole farm-to-table continuum is covered. In the board, all relevant directorates, the National Health Screening Service, the KNT, the Norwegian School of Veterinary Science, and the Consumer organization is represented. The Norwegian Zoonosis Centre collects, analyses, and presents epidemiological data on zoonoses and zoonotic agents in Norway to prevent transmission through food, feed, animals, and animal products. Amongst others, the Norwegian Zoonosis Centre is responsible on behalf on the Ministry of Agriculture for producing the annual Norwegian report on zoonoses and zoonotic agents according to the EU Zoonosis Directive. The Norwegian Zoonosis Centre is a dynamic coordinating unit that works closely together with the other institutions with responsibilities and activities in the area of Zoonosis. Communication and information, also with the general public, is a prioritised task.

\subsubsection{Control and Registration of Imported Food}

The control and registration of imported foodstuffs of animal origin is carried out according to EU legislation. As a consequence of the EEA-Agreement between EFTA and EU, Norway is recognised as a part of the internal market. Regarding food products entering Norway from third countries, there are 16 border inspection posts (BIP) responsible for veterinary checks. The inspection posts are dedicated for different kinds of products and live animals. SNT, SDT, and FD are each responsible for the border inspection under their respective jurisdiction.

Foodstuffs of animal origin from third countries are controlled in accordance with Council Directive 97/78.

Control of foodstuffs of animal origin from the EEA-area is carried out by the municipal authorities in accordance with Council Directive 89/662. The control will take place at the first establishment where the goods arrive. In addition, control of imported foodstuffs of non-animal origin will be carried out in accordance with national regulations.

Table 5 shows the import of selected important foodstuffs in 1995.

Today, Norway is self-sufficient with most of the foodstuffs naturally produced in the country. The volume of imported foodstuffs to Norway has not changed significantly during recent years. During the last twenty years Norwegian production has increased substantially, first of all due to an increase in grain production in Norway.

The export of fish has increased. Thus, Norway is a net exporter of foodstuffs. 
Table 5. Amount (in tonnes) of certain imported foodstuffs.

\begin{tabular}{|l|l|}
\hline Type of Foodstuff & Amount Imported, 1995 \\
\hline Vegetables & 90.000 \\
Fruit/berries & 250.000 \\
Grain & 150.000 \\
Poultry & 1.000 \\
Cheese & 2.500 \\
Meat & 15.000 \\
\hline
\end{tabular}

\subsubsection{Monitoring/Surveillance of Zoonotic pathogens}

\subsubsection{Brucella sp.}

Brucellosis is a zoonotic disease that can be controlled already at primary production. Bovine brucellosis has been a notifiable disease since 1903. An offensive campaign to eliminate the disease was launched in 1935. In 1953, bovine brucellosis was deemed eliminated from Norway. Norway has been granted the status of officially brucellosis freedom of bovine herds.

Ovine and caprine brucellosis have never been recorded in Norway, and Norway is considered as satisfying the criteria of officially brucellosis free status for sheep and goats. Porcine brucellosis (B. suis) has never been recorded in Norway.

To document the absence of bovine brucellosis, extensive surveillance programmes have been implemented. A surveillance programme in regard to porcine brucellosis is also in place. There are no official monitoring programmes in regard to brucellosis in sheep and goats.

If brucellosis is detected in bovine, ovine, caprine, or porcine animals the infected herd will be stamped out. In addition, epidemiological investigations will be initiated. Vaccination of animals against brucellosis is prohibited, as this will interfere with potential epidemiological investigations.

Brucellosis in man is a notifiable disease. Human brucellosis has always been a rare disease in Norway. The few recorded cases in recent years have been imported.

\subsubsection{Tuberculosis}

Bovine tuberculosis (M. bovis) is also a zoonotic disease that can be controlled already at primary production. Bovine tuberculosis was deemed eliminated from Norway in 1963 and Norway has been granted the status of officially tuberculosis freedom of bovine herds.

Tuberculosis (M. bovis and M. tuberculosis) is a notifiable disease of all animal species. If tuberculosis in cattle is detected, the infected herd will be stamped out. Surveillance of the disease is based upon the routine procedures concerning tuberculosis, which have to be followed at the meat inspection throughout the country, as well as the general 
monitoring of the clinical health status of the cattle population. Every bovine animal, except those slaughtered for on-the-farm consumption, is subjected to a post-mortem examination at the slaughterhouse (lymph node examination) by an official veterinarian according to Community legislation. If findings suggestive of tuberculosis are made, samples are submitted to the National Veterinary Institute for cultivation and histological examination.

Should any suspicion of tuberculosis arise in live animals, tuberculin testing is carried out. Moreover, pathological/bacteriological examinations may be performed at autopsy if indicated. Tuberculin testing is an integral part of health control of bulls used as semen donors and is also done in relation to imports and exports.

Animals testing positive by the tuberculin test will be culled and subjected to postmortem examination. The farm of origin will be subjected to restrictions, and relevant animals will be tuberculin tested.

If M. bovis or M. tuberculosis is detected, the whole herd will be stamped out. In addition, epidemiological investigations will be initiated.

Vaccination of animals against tuberculosis is prohibited.

Human tuberculosis caused by M. bovis or M. tuberculosis is a notifiable disease. The incidence of human tuberculosis (M. bovis and M. tuberculosis) has steadily decreased during the last 50 years in persons of Norwegian origin. BCG vaccination was introduced in 1947 and was mandatory until 1995. Pasteurisation of milk for commercialisation became mandatory in 1951. Most cases in recent years in persons of Norwegian origin are recurrent cases in elderly patients. Along with increased immigration to Norway, the proportion of tuberculosis cases involving persons of non-Norwegian origin has increased during the last two decades (from less than 10\% in 1977 to $66 \%$ in 1999).

The last case of domestically acquired tuberculosis caused by M. bovis was reported in 1994 in a 100-year old woman infected in her youth. Apart from this case, no indigenous cases of tuberculosis caused by M. bovis in man have been reported since 1977. Since bovine tuberculosis in cattle was eliminated in Norway in 1963, an increasing proportion of tuberculosis in man is caused by M. tuberculosis.

\subsubsection{Salmonella sp.}

As mentioned in 6.4.1.2, Norway has implemented surveillance programmes for Salmonella in regard to live animals, meat and poultry, and feedstuffs.

As a general rule, analyses must be performed by laboratories that are accredited for the methods used. All isolations of Salmonella sp. from animal feed, live animals, food, and man are referred to the National Reference Laboratory at the NIPH for confirmation. Here, serotyping is performed to identify serovar. Antimicrobial susceptibility testing is done for all isolates of Salmonella sp. Phage typing is performed for all $S$. Typhi and $S$. Paratyphi, for multiresistant $S$. Typhimurium, and for outbreak isolates of $S$. Typhimurium and $S$. Enteritidis. A special attention is paid to multiresistant $S$. Typhimurium DT 104.

\section{Feed}

Large resources are directed towards the control of Salmonella sp. in animal feed. The authorities run official surveillance programs based upon random sampling in the establishments. In addition, there are official requirements of internal control for Salmonella 
sp. in production plants for complete feedingstuffs, for establishments producing meat and bone meal, fish feed, fish meal, or fish oil, and for establishments preparing feed for fur animals. Moreover, there are requirements of internal control for Salmonella sp. when importing feed materials of vegetable origin from the EEA area and third countries. Feed materials including fish meal imported from third countries must be subjected to control for Salmonella sp. according to a specified plan before distribution or use. Dog treats made from hides that are imported from third countries must be accompanied with a certificate that documents that the lot has been controlled for Salmonella sp. At the border control, sampling is done according to a specific scheme.

In addition to the monitoring programmes, feedingstuffs are subjected to analyses for Salmonella sp. in relation to epidemiological investigations and specific surveys and projects.

If Salmonella sp. is detected in feedingstuffs, equipment, or production plants the relevant authority must be informed without delay. The establishment must take action according to a defined procedure to prevent the distribution of contaminated feed. Contaminated feed will be destroyed or heat-treated.

The Norwegian Agricultural Inspection Service and the Directorate of Fisheries are responsible for the control of feedingstuffs for terrestrial animals and fish, respectively.

\section{Animals}

The Norwegian Salmonella control programmes includes a surveillance programme among live animals. This surveillance comprises analyses of faeces, meconium or organs from poultry (breeders, layers, and poultry for meat production) and breeder pigs as well as analyses of lymph nodes from randomly selected slaughtered cattle and pigs. Annually, the necessary total of samples to detect Salmonella sp. at an animal prevalence level of $0.1 \%$ (with $95 \%$ confidence level) is collected from the cattle and swine population at slaughter. In addition, all elite breeding pig herds and all poultry flocks exceeding a certain size are surveyed at herd level. Sampling of breeder flocks of Gallus gallus is carried out in accordance with the programme laid down in Annex III of Council Directive 92/117/EEC. Analyses must be done at an officially approved laboratory.

In addition to the above, live animals are tested for Salmonella sp. on clinical indications, in relation to import, in relation to epidemiological investigations, and in specific surveys or studies.

Detection of Salmonella sp. is compulsory notifiable. If Salmonella sp. is detected in livestock, restrictions are imposed on the movement of animals from the farm, and epidemiological investigations to identify and eliminate the source of the infection are initiated. Action includes restrictions on animal movement that are put on farms and not lifted before the infection has been eliminated. Poultry flocks infected with invasive serovars will be destroyed. It is emphasized that $S$. Enteritidis never has been detected in Norwegian poultry production.

\section{Food}

The Norwegian Salmonella control programme for red and white meat comprises analyses of randomly sampled swabs from carcasses of pigs, cattle, and sheep, neck skin samples from poultry carcasses, and samples of crushed meat collected at different meat processing establishments. Annually, a number of samples sufficient to detect Salmonella sp. at a prevalence level of $0.1 \%$ (with $95 \%$ confidence level) are collected from 
carcasses of cattle, swine, and sheep. Extensive monitoring of cutting plants and poultry slaughterhouses is also carried out.

In addition to the above, food products are tested for Salmonella sp. in relation to epidemiological investigations, as part of internal control in the food production and food processing establishments, in relation to import (border control for food imported from third countries, and randomly in the market for food entering Norway from EEA countries), and as part of specific surveys and studies.

Whenever Salmonella sp. is detected, action is taken to prevent people from being infected by contaminated food products and to identify and eliminate the source of the contamination.

MSIS-data (see 6.4.3.2) show that annually approximately $80-90 \%$ of reported cases of salmonellosis have acquired the infection abroad. This illustrates that domestic food products of animal origin represent a negligible risk to the consumer in regard to Salmonella sp., an assumption that is supported by case-control studies.

\section{Human incidence data}

Salmonellosis in humans is a notifiable disease. As described in 6.4.3.2, the MSIS at the NIPH collects data regarding salmonellosis as well as other communicable diseases in humans. The annual incidence is relatively high (in recent years approx. 30 per 100.000). However, $80-90 \%$ of registered cases have acquired the disease abroad.

\subsubsection{EHEC/VTEC}

An official surveillance programme in regard to EHEC in carcasses from cattle was established in 1998 by the SNT, and since 1999 this programme also includes sheep and goats. At the slaughterhouses carcasses are sampled at a defined frequency. Currently, the samples (from the abdominal incision area) are only tested for the presence of bacteria belonging to the serogroup E. coli O157. The sampled carcasses are arrested during analyses. A carcass that tests positive for VTEC O157 will be condemned. The SNT, the District Veterinary Officer, the municipal medical officer, and the Norwegian Zoonosis Centre will be informed about the findings. The effectiveness of this surveillance programme will probably be evaluated in 2001 .

Since 1996, the SNT has funded annual surveys regarding EHEC in selected food product categories, such as imported beef and domestically produced raw milk products. If VTEC O157 is detected, follow-up sampling will be initiated. Depending on the type of products, efforts will be made to prevent similar products entering the market. Relevant information/education strategies will be launched.

In 1998, the Norwegian Animal Health Authority (SDT) initiated a monitoring programme in regard to the prevalence of EHEC (currently only E. coli O157) in live cattle (faecal samples). This programme consists of annual surveys in selected animal populations. In addition, the SDT follows up with faecal sampling in those herds from where the animals testing positive in the carcass programme originate. If VTEC O157 is detected the District Veterinary Officer (DVO), the municipal medical officer, and the Municipal Food Control Authority must be notified. Generally, no official restrictions are placed on cattle holdings where VTEC O157 is detected. However, there have been incidents where animals have been prohibited from participating at fairs and exhibits due to the risk to humans. Advise regarding human health aspects are provided to the farmer by the DVO. Herds found positive are followed up with extensive testing four 
times in the following year. If animals from a positive herd are to be slaughtered, the DVO notifies the Veterinary Officer at the slaughterhouse. This routine ensures that these animals are slaughtered separately

EHEC infection has been a notifiable disease since 1995. So far, the annual reported incidence has been low (0-0.3 per 100.000). However, it is acknowledged that this situation may suddenly change, and the situation is closely followed. Most cases have been sporadic, and approx. half of the cases have been imported.

\subsubsection{Campylobacter sp.}

Currently, no monitoring programme has yet been implemented in regard to the prevalence of Campylobacter sp. in live animals or food products. However, in recent years the SNT has funded several surveys in regard to the prevalence of Campylobacter sp. in poultry flocks and in retail poultry of domestic and imported origin. Surveys are also being conducted by the food industry. A survey administered by the Norwegian Zoonosis Centre regarding the occurrence of Campylobacter sp. in dog and cats is currently going on.

Detection of Campylobacter sp. in ready-to-eat food products, but not in fresh meat and poultry, will result in withdrawal from the market of the contaminated food.

Isolation of Campylobacter sp. in from animals is not compulsory notifiable, and no measures have to be implemented in case of positive findings in animals. However, the poultry industry has been using prevalence data as an incentive for improving the hygienic conditions on poultry farms.

In 2001, a surveillance programme in regard to Campylobacter sp. in poultry will probably be launched.

Campylobacteriosis in humans is a notifiable disease. In recent years, the annual incidence has increased dramatically, a situation that is of great concern and is being addressed by several means (e.g., conducting case-studies, considering implementing a surveillance programme in poultry, increasing public information, more focus on water quality).

\subsubsection{Listeria monocytogenes}

Listeria monocytogenes is a zoonotic pathogen that, according to current knowledge, cannot be controlled in primary production. However, control can be and should be achieved in successive steps of food production systems where Listeria monocytogenes contamination represents a health risk. Currently, there are no official monitoring programmes in regard to L. monocytogenes in food products (except for smoked salmon being exported to the USA according to a specific agreement). However, each year the SNT funds several surveys regarding the occurrence of $L$. monocytogenes in selected food products, e.g., raw milk cheeses of domestic and imported origin. The SNT recommends that findings of L. monocytogenes in ready-to-eat food products with a shelf life longer than 15 days and in which the bacteria easily can grow should result in recall from the market of the corresponding lot. The producer is recommended to review production routines and shelf-life of the product. Findings of L. monocytogenes in some specified heat-treated products (e.g. soft cheese) would result in recall of the corresponding lot. 
Analyses are also performed as part of the internal control in the food industry, especially in relation to fish products. Corrective actions will be taken according to the frequency of positive findings, product type, step of process at which the isolation was done, and whether the product is a ready-to-eat-product or special dietary products.

Listeriosis in humans is a notifiable disease. The annual incidence has so far been relatively low (2-21 cases per 100.000), and most cases have been sporadic.

\subsubsection{Yersinia enterocolitica}

Yersinia enterocolitica is a zoonotic pathogen for which preventive measures can be introduced at abbatoir level. There are no official monitoring programmes in regard to $Y$. enterocolitica in food products. However, the SNT has funded several surveys regarding the prevalence of $Y$. enterocolitica in pork. Furthermore, the industry conducts regular surveys.

Surveys conducted during the 1980s showed that a large proportion of Norwegian pigs were carriers of $Y$. enterocolitica serogroup O:3 and that the same variant frequently could be isolated from pig carcasses. A case-control study identified consumption of pork as an important risk factor for yersiniosis.

Since 1994, a reduction in the incidence of yersiniosis in humans has been identified. This decline has coincided with the gradual introduction of improved slaughtering routines that aid in preventing carcasses from becoming contaminated with Y. enterocolitica. Results from a survey conducted in 1997-1998 indicated that the prevalence of pathogenic $Y$. enterocolitica in Norwegian pork products had decreased since a similar survey was conducted in 1988-1989. This decrease is most likely due to changes in the slaughtering routine, especially the introduction of the «bagging» technique (enclosure of the rectum in a plastic bag).

Yersiniosis in humans is a notifiable disease. The annual incidence has so far been relatively moderate, and has decreased from an average of 4.5 per 100.000 in 1982-1994 to 3.0 in 1995 and 2.8 in 1999. Most cases have been sporadic, and 25-30\% have been imported.

\subsubsection{Surveillance of Antimicrobial Resistance}

The Norwegian action plan against antimicrobial resistance, issued by the Norwegian Ministry of Health and Social Affairs in 2000, stressed the importance of monitoring the occurrence of antimicrobial resistance in both the human and veterinary sector, including food production. A monitoring program for antimicrobial resistance in human pathogens was established in Norway in 1999, NORM (Norwegian monitoring programme for resistance in microbes). In the veterinary and food sector, surveys regarding antimicrobial resistance in relevant bacteria from various sources, including pathogens and/or indicator bacteria, have been conducted annually in recent years. A continuous monitoring program in the veterinary and food sector (NORM-VET) was established in the fall of 2000. In this program, which is administered by the Norwegian Zoonosis Centre, samples from animals, feed, and food are being collected and analysed in a systematic and representative manner. The results will be presented in annual NORM-VET 
reports to document and follow the resistance situation. The NORM-VET reports will also include data on usage of antimicrobial agents in the veterinary sector. These consumption data are collated and analysed at the Norwegian School of Veterinary Science. Together, the resistance data and consumption data can serve as a basis for the interpretation and evaluation of trends in the resistance situation in Norway in the future.

\subsubsection{Risk Assessment Activities}

Risk management is carried out at the SNT, the SDT, the FD, or the LT depending on the issue, and on many occasions (e.g., BSE), several directorates will be involved. Risk assessment on the other hand, is conducted in scientific institutions or by the Scientific Committee of SNT. Historically, non-formalized ad hoc qualitative or semi-quantitative risk assessments have been the basis for microbiological risk assessment. Efforts are going on to build up competence and to increase the use of formalized, structured (semi)-quantitative risk assessments.

Risk assessments activities currently going on in regard to microbiological food safety include Campylobacter sp., Listeria monocytogenes in fermented fish, Salmonella, and BSE. Case-control studies carried out in relation to Campylobacter, Yersinia, Salmonella and Toxoplasma infections have been helpful in order to retrospectively estimate relative risks associated with different risk factors, and to calculate attributable fractions.

\subsubsection{Strengths and Weaknesses of the Norwegian System}

\subsubsection{Strengths:}

- A farm-to-table perspective in food safety

- Many data throughout the food chain

- Quality assurance of data

- A well-functioning Salmonella surveillance and control programme

- Generally good collaboration between the various institutions, formally and informally

- Good collaboration between the veterinary and human sector

- Separation between risk analysis and risk management, although there is overlap

- A transparent, open, communicative system

- Case-control studies

- A Zoonosis Centre

- NORM-VET has been established

- Good Nordic collaboration, formally and informally

\subsubsection{Weaknesses:}

- Not sufficiently co-ordinated or planned control throughout the food chain from farm to table. The establishment of the Norwegian Zoonosis Centre has helped to improve this, but work still remains 
- Data reporting and collection can be improved

- Many data from the local authorities not available for the central institutions

- Insufficient exploitation of the data from survey/surveillance/research

- Collaboration often dependent on personal contacts, not formalized

- Many participants, not clear definitions of the roles and responsibilities

- Limited resources locally/regionally/centrally and not sufficient exploitation of resources

- Activities are often not planned well enough and given enough continuation

- Risk analysis has not been prioritised well enough

- Are the costs related to Salmonella surveillance unnecessary high and nonproportionate as compared to other areas? 


\subsection{Sweden}

\subsubsection{Overall National Policy}

\subsubsection{Salmonella, all serotypes:}

The prevalence of Salmonella in feed, live animals and animal products, produced in Sweden is extremely low. This unique position has been achieved by a national strategy of control, from feed to food, which was initiated more than 40 years ago. The overall aim of the Swedish Salmonella control programme is that animal sent for slaughter shall be free from Salmonella, thereby animal products for human consumption shall be free from Salmonella. Any food item contaminated with Salmonella is deemed unfit for human consumption.

The strategies to reach this aim are as follows:

- To prevent Salmonella contamination of all parts of the production chain

- To survey/monitor the whole production chain. Surveillance programmes for feed, live animals, carcasses, meat and food of animal origin are in place

- At any finding of Salmonella, necessary actions are taken to eliminate the Salmonella infection/contamination. Trace back investigations aiming at identifying the source of infection as well as any spread of infection are instituted.

Although the Swedish Salmonella control programme covers feed, food and all livestock, only cattle pigs, poultry and products thereof are included in the EU-approved Salmonella control program

\subsubsection{VTEC/EHEC O157 and other serotypes:}

At present, the knowledge about the VTEC-epidemiology is not sufficient to initiate a control programme. Surveys have shown that VTEC O157 is not uncommon among Swedish cattle. The national strategy has focused on preventing infection in humans. SBA, SIIDC, NFA, NBHW and the Zoonosis Centre at NVI have established a national strategy document that is continuously revised as the knowledge of VTEC/EHEC increases.

\subsubsection{Campylobacter:}

As the epidemiology of Campylobacter in not fully known, a national strategy for controlling Campylobacter has not been established. As it is known that chicken may be an important reservoir and source of infection a voluntary control program aiming at reducing the prevalence of Campylobacter positive flocks is in place. At present, approximately $10 \%$ of broiler flocks are infected with Campylobacter (on an annual basis). Campylobacter is considered a pathogen of high priority. Therefore, the Zoonosis Council has taken initiative to co-ordinate activities within the veterinary, human and food fields. 


\subsubsection{Other zoonotic agents}

Concerning other zoonotic agents an ad hoc, but not formalised, co-operation occurs between the relevant actors.

\subsubsection{Food Safety Legislation}

In Sweden, food legislation is made at three levels:

- the Food Act issued by the Swedish Parliament is a frame law, containing definitions and principles concerning inter alia food composition, handling, labelling, offering for sale, personnel hygiene, food premises, supervision/ control, penalties and appeals. It also empowers the Government, or an agency appointed by the Government, to issue regulations on food.

- the Food Decree issued by the Government develops the rules of the Food Act in some greater detail and gives the National Food Administration the power to issue further regulations in the food area and to approve food premises in certain types of establishment. The Decree also appoints supervisory authorities for all kinds of establishments handling food.

- Ordinances issued by the National Food Administration contain detailed regulations on inter alia food standards, labelling, food handling, additives, contaminants (pesticide residues, veterinary drug residues, heavy metals, mycotoxins etc.), supervision and in-house control, food premises, personnel hygiene, drinking water, veterinary food control, export control, import control, food control laboratories and material for food contact use. The NFA issues binding regulations and also provides advice concerning the application of such regulations.

Sweden joined the European Union (EU) on 1 January 1995 and has harmonised its food legislation with that of the EU. As a member of the EU, Sweden takes part in the development of new EU legislation in the food area. European Community Regulations apply directly in Sweden. European Community Directives are transposed into NFA Ordinances. EU's zoonosis directive with the aim of regulating the member states surveillance and reporting on zoonoses, has been implemented in Sweden.

For foods sold in Sweden, the standards and other regulations, which apply, are the same or equivalent for domestically-produced and imported foods. If the importing country so demands, special standards or regulations may apply for foods produced in Sweden for export to that country.

\subsubsection{Overall Structure}

\subsubsection{Political Structure}

The food control from farm to table is within the purview of the following ministries (Fig 10):

Ministry of Agriculture, Food and Fisheries

Ministry of Environment

Ministry of Health and Social Affairs

Ministry of Finance 
Their responsibilities related to zoonotic diseases are as follows:

Ministry of Agriculture, Food and Fisheries is responsible for issues relating to agriculture and fisheries and matters relating to food. It is the head of the Swedish Board of Agriculture (SBA), the National Food Administration (NFA), and National Veterinary Institute (NVI).

Ministry of Environment is responsible for eco-cycle principles and the policy for sustainable development. It is the head of the Swedish Environmental Protection Agency (EPA).

Ministry of Health and Social Affairs is responsible for health and medical care for humans. It is the head of the National Board of Health and Welfare (NBHW), Swedish Institute for Infectious Disease Control (SIIDC), and the County Medical Officers.

Ministry of Finance is the head of the County Administrative Boards. County Veterinarians, employed by the County Administrative Boards directs and co-ordinates actions taken concerning zoonotic agents in animals. The County Administrative Boards have regional responsibility for supervision of food and are involved in issues concerning waste products.

In Sweden the ministries have the economical and over all responsibility for the above mentioned agencies. Day to day activities are delegated to the operative agencies

$\underline{\text { Swedish Municipalities (Local authorities) are responsible for control of food and food }}$ products at the retail level, restaurants and large-scale households and certain cutting plants. NFA is supervisor for the food control performed by the Swedish Municipalities. The local authorities are free to organise the local food inspection according to the constitutional provided self government.

\subsubsection{Food Control Organisation}

The National Food Administration (NFA) is responsible at the national level for enforcing the Food Act and regulations issued under the provisions thereof. The County Administrations have responsibility for co-ordinating food control at the regional level and the municipal Environment and Health Protection Committees have responsibility for food control at the local level.

The organisation and financing of food control in Sweden is currently under review. This review includes the question of the division of responsibility for food control between the NFA and the municipalities.

\section{National level}

The NFA inspects slaughterhouses, dairies, egg product establishments, exportcontrolled establishments and other very large food-producing establishments (in all 
some 600 establishments) and food premises in railway carriages, aircraft and certain ships. In addition, the NFA provides advice to the regional and local supervisory authorities, the food industry and trade. It also initiates food control projects, which are carried out by the local authorities and follows up the results of food control carried out at the municipal level. The municipal authorities supervise about 51.500 establishments (shops, catering establishments, smaller food factories, waterworks, etc.).

The NFA organises the control of pesticide residues in fruit, vegetables and cereals. Samples are collected at ports of entry or wholesale markets. They are analysed at laboratories working under contract to the NFA and the results are transmitted directly to the NFA's computer. The results of the control of pesticide residues are published annually.

The NFA also organises the control of veterinary drug residues in foods of animal origin, mainly meat. Samples are collected at farms, slaughterhouses or ports of entry and are analysed at the NFA or at laboratories working under contract to the NFA.

The NFA has overall responsibility for import and export control. For food from countries outside the EU, inspection and sampling for microbiological (Salmonella, etc.) examination at import control is carried out by the Environment and Health Protection Authorities at Border Inspection Posts. Please see the organisation of NFA, figure 9.

\section{Regional level}

Each of the 21 County Councils in Sweden is responsible for co-ordinating food control at the regional level, but they do not usually carry out any direct food control.

\section{Municipal level}

The local municipal authorities carry out food control at all food handling establishments except those under the supervision of the NFA, including food production establishments, wholesalers, retailers, catering establishments, waterworks and importers.

Approximately 1,000 inspectors are involved in food control at the municipal level. However, some of these only work part-time with food control and the personnel involved in food control correspond to about 300-350 full-time inspectors.

Food samples collected by the municipal food control authorities are usually analysed by private laboratories accredited by the Swedish Board for Accreditation and Conformity Assessment (SWEDAC).

\section{Financing of control, etc}

The work of the NFA is financed partly by an annual appropriation from the Government (ca.106 million Swedish crowns for 1998) and partly by fees paid by the food industry and trade (ca.159 million SEK in 1998) - in all ca 265 million SEK. The meat inspection service is financed entirely by fees collected from the slaughterhouse operators. Municipal food control is financed partly by local taxes and partly by fees collected from the food industry and trade for sampling and analysis.

All establishments producing or handling foods (except very small operations) are required to pay an annual food control fee to the supervisory authority, i.e. the NFA or the municipal food control authority. 


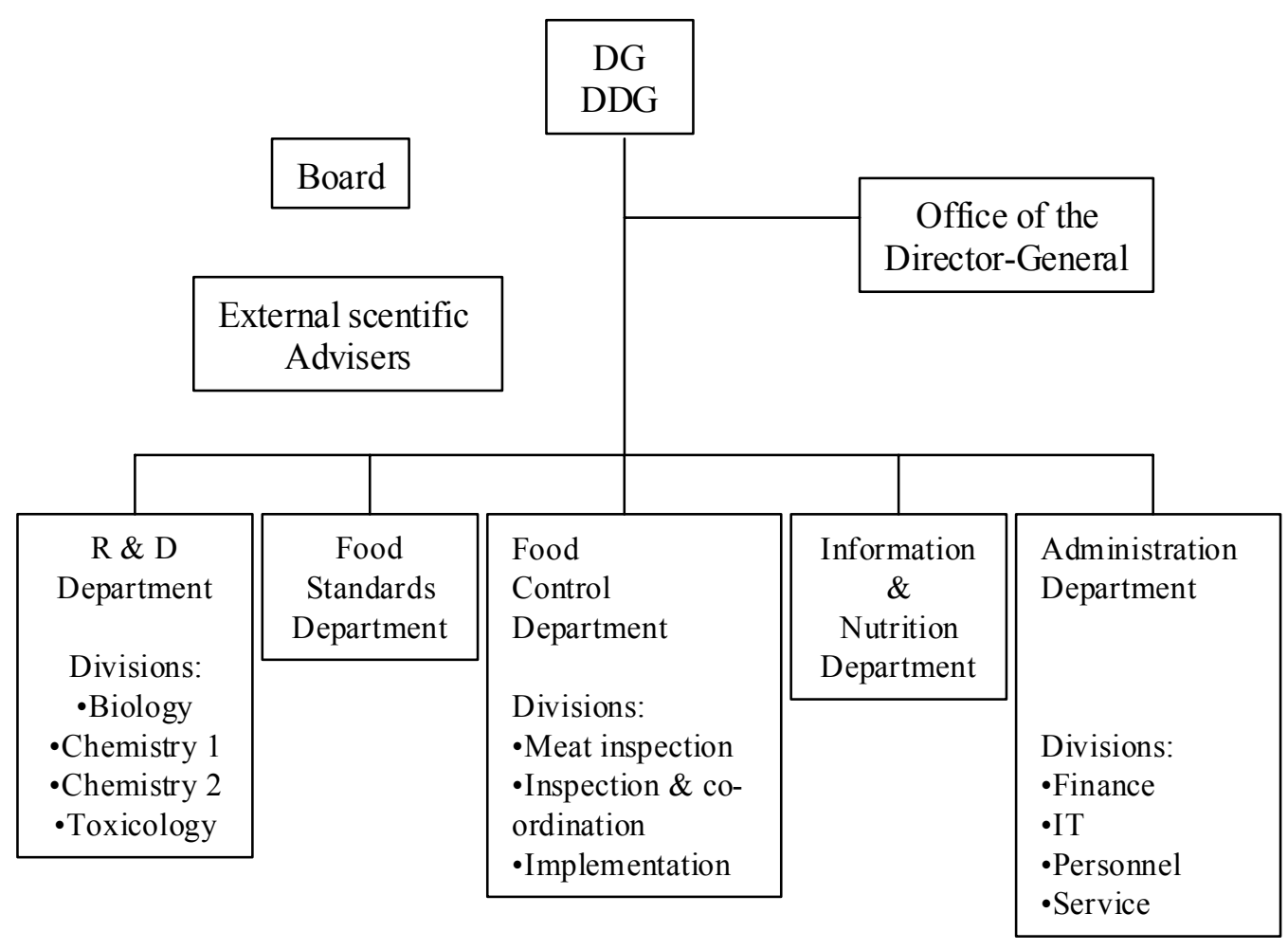

Figure 9. Organisation of the National Food Administration. (DG = Director general, DDG $=$ Deputy Director-General.) 


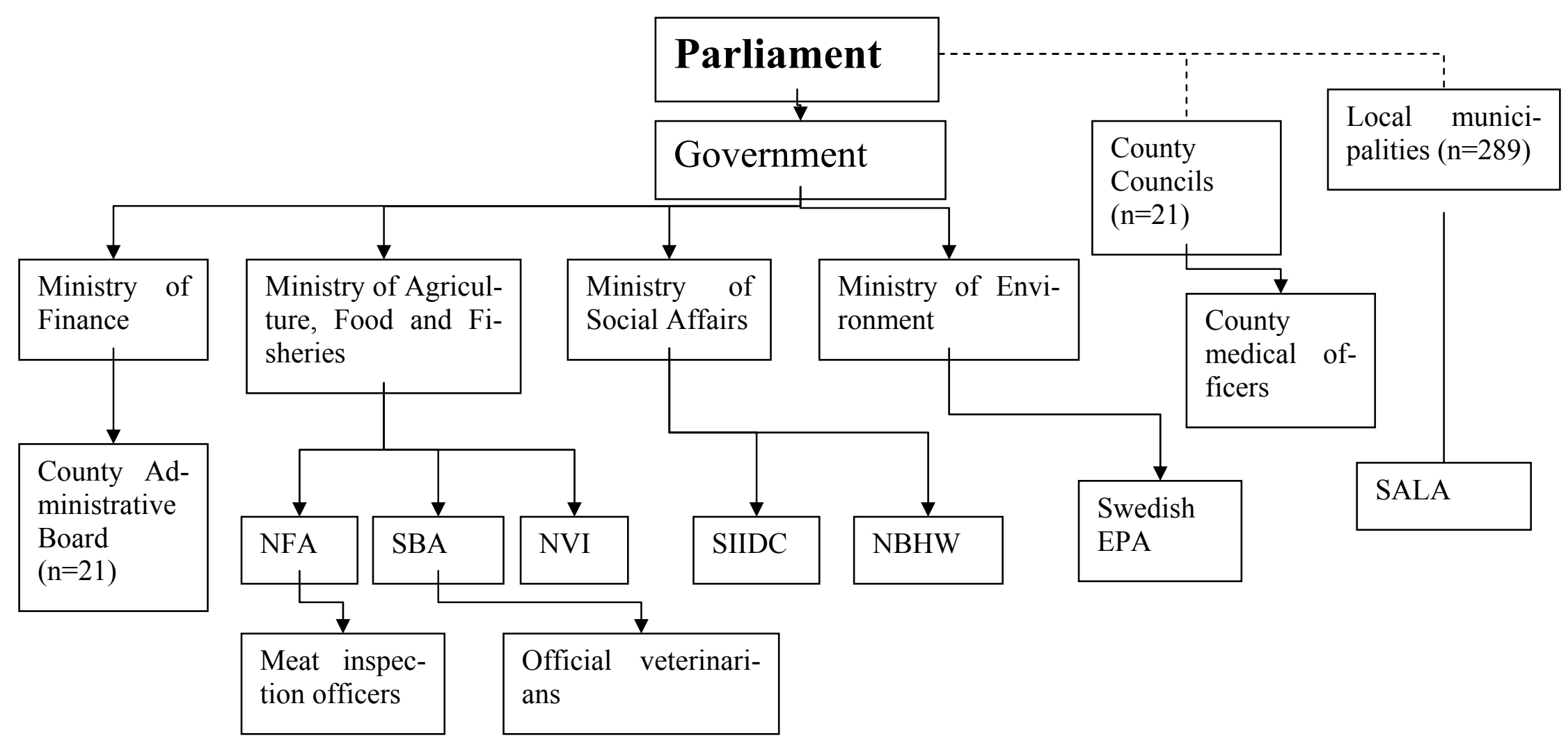




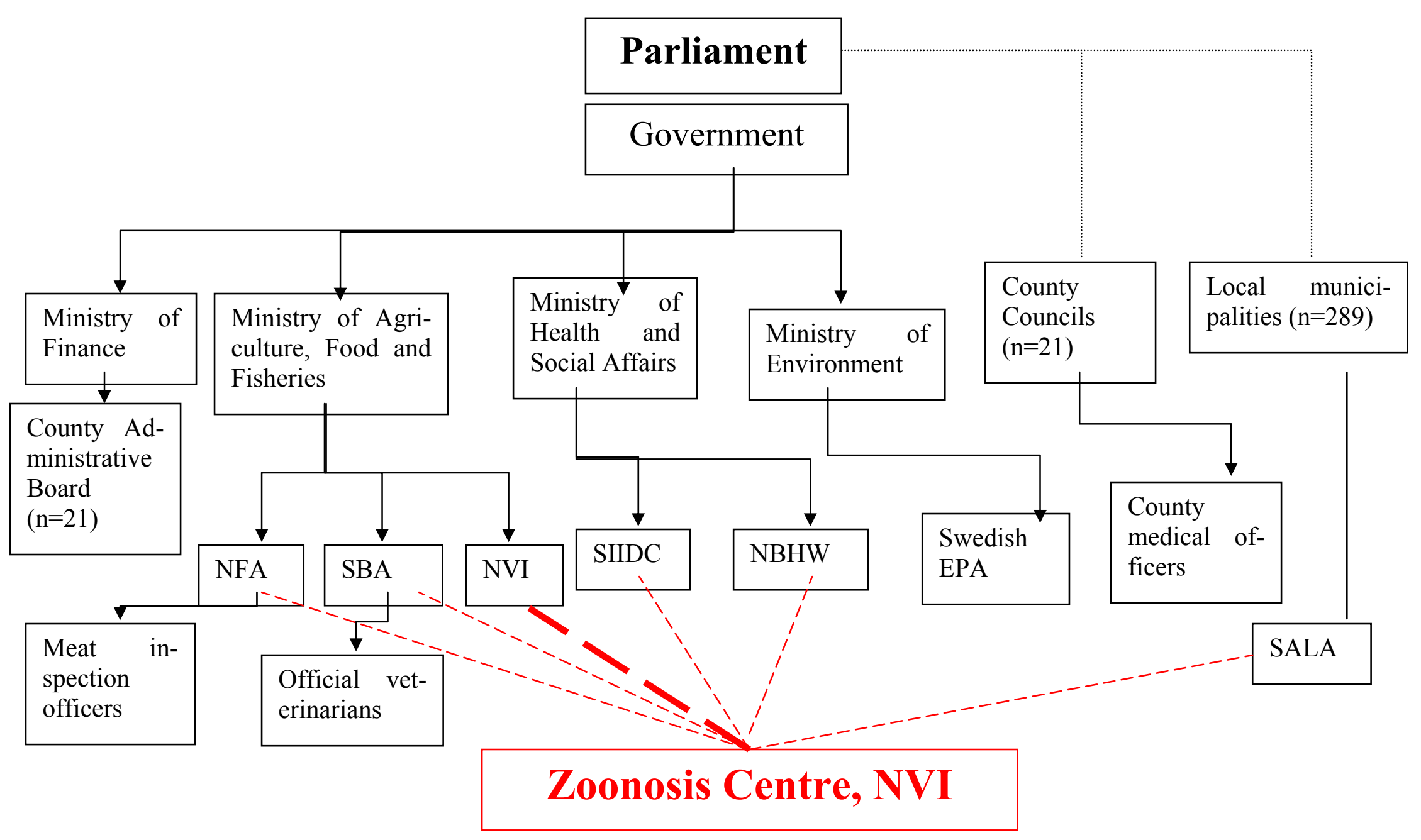

Figure 11. Co-ordination of activities within food control in Sweden. 


\subsubsection{Zoonosis Network}

A Zoonosis Council was established in Sweden in 1997 as a common forum for authorities handling topics related to zoonotic diseases/agents and antibacterial resistance issues. Members of the Zoonosis Council are the NBHW, the SIIDC, the NFA, the SBA and the NVI. Furthermore, the SALA and the Department of Food Hygiene, Faculty of Veterinary Medicine are additional members (Figure 11). The Zoonotic Council meets approximately four times a year.

The Swedish Zoonosis centre is an investigating and executive body for the Zoonosis Council. It is located at the NVI and employs five people, three veterinarians and two laboratory technologist (one full time and one part time).

\subsubsection{Control and Registration of Imported Foodstuffs}

The control and registration of imported foodstuffs is subject to the EU regulation. Prior to 1995 all statistics concerning imported food was based on the border control performed by the Customs. From 1995 and onwards (Sweden joined the EU $1^{\text {st }}$ of January 1995) import from third countries is still based on border controls. Statistics regarding import from EU-countries are based on information from importers. Furthermore, a report only has to be made if food for more than 900000 SEK is imported annually. From the $1^{\text {st }}$ of January 1998 this limit was raised to 1.5 million SEK. In 1995 the categorization of imported food was changed, thereby making it more difficult, or maybe impossible, to compare figures before and after 1995.

During the period from 1990 to 1998 the Swedish import of meat and meat products (in 1000 ton) has more than doubled (figure 12).

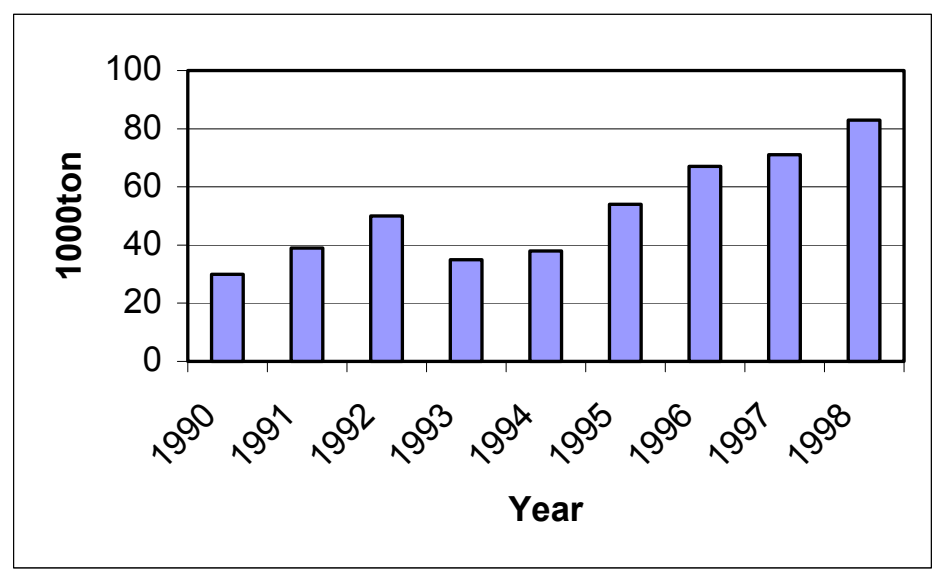

Figure 12. Import of meat and meat products imported from EU and third countries to Sweden from 1990 to 1998.

Official veterinarians at border inspection posts, control foodstuff of animal origin, imported from third countries, for Salmonella. Food of animal origin (from cattle, pigs and poultry) from EU-countries is controlled for Salmonella at the establishments of origin, according to the Swedish Salmonella guarantees as regulated in directive 64/433/EC and $71 / 118 / \mathrm{EC}$ respectively. In certain cases, the control is performed at the receiving establishment in Sweden. 
Heat-treated products are not controlled for Salmonella.

Food of other animal origin (sheep, goat and equine animals) from EU countries has to be controlled for Salmonella by the receiving establishment in their internal reception control. This is regulated in the Swedish ordinances SLVFS 1998:39.

In addition, the local municipalities perform official controls and sampling in the retail businesses.

\subsubsection{Monitoring/Surveillance of Zoonotic Pathogens}

\subsubsection{Salmonella}

All isolations of Salmonella are notifiable. All isolates of Salmonella are characterized by sero-typing the strains.

\section{Feed}

Findings of Salmonella spp. in the feed sector are compulsory notifiable.

Domestic feed materials of animal origin are controlled according to the present EU legislation where each consignment produced is kept under quarantine until the results of Salmonella investigations have been completed. Importation of feed materials of animal origin is limited to products for the pet food industry. This material is tested for the presence of Salmonella before import, in the country of origin.

Major domestic producers of feed materials of vegetable origin are required to analyse their products for the presence of Salmonella. Imported feed materials of vegetable origin are investigated for Salmonella when the consignment has reached its Swedish destination or at the point of exportation.

In the feed mills, much effort is used on the hygienic conditions and the process control (HACCP). Sampling is carried out in the feed mills by investigating scrapings from critical control points in the processing equipment. Five samples (minimum) are investigated every week from feed mills producing poultry feed. For other feed mills two critical control points are investigated per week. The present monitoring system, covering more than $95 \%$ of the feed production, allows an early detection of Salmonella spp. in the feed mill. Results of the compulsory HACCP sampling at feed mills during 1999 showed 24 positive out of 2851 samples $(0.8 \%)$ collected before heating and 3 positive out of 4276 samples $(0.07 \%)$ collected after heat treatment (clean side).

Rendering plants are controlled according to the present EU legislation. Each batch has to be tested negative before delivery and environmental samples are collected in the building and from the equipment. Number of samples depends on the size of the plant and is not specified in the EU legislation

\section{Animals}

The Swedish Salmonella control programme was initiated in 1961 and it covers all food producing animals. In 1995, certain parts of the programme, covering cattle, pigs poultry and eggs, were approved by the EU (95/50/EC) and an extended surveillance programme was initiated. Results of the surveillance show that Swedish red and white meat and eggs are virtually free from Salmonella. 


\section{Poultry and eggs}

Sampling strategies are outlined in the Swedish Salmonella control programme approved by the EU. Microbiological sampling of breeding flocks is carried out according to Council Directive 92/117/EEC. In addition, more frequent testing is carried out in the elite and grand parent generation. During the rearing period, sampling is done on 5 separate occasions. Tissue samples (caeca) are taken as a supplement to the faecal sampling. During egg production faecal samples are taken from the breeders every month as a supplement to the sampling in the hatchery.

The parent generation is tested during the rearing period by tissue sampling as well as faecal sampling. During egg production, samples are taken as has been described for grand parents.

Ratite breeders are tested every third month by faecal samples. All meat production flocks broilers, turkeys and ducks, ratites and geese are investigated by faecal sampling 1-2 weeks before slaughter. In broilers additional sampling is carried through. 30 samples of caecum tissue are collected 1-2 weeks prior to slaughter. Pullets are tested (faecal samples) once during the rearing period, 2 weeks before moving to a laying unit. Sampling of laying flocks with more than 200 layers from establishments not placing eggs on the market and of all laying flocks from establishments placing their eggs on the market is carried out as faecal samples three times during production. All faecal samples are collected according to Council Directive 92/117/EEC. Since April 1998, flocks of egg-producing quail are sampled twice a year by faecal sampling.

Within to the control programme, neck skin samples are taken from poultry at slaughterhouses. Annually approximately 4000 samples are collected at slaughterhouses and analysed.

\section{Cattle and pigs}

The Salmonella control program in cattle pigs and other food producing animals consists of:

- Surveillance of herds/ breeding herds at farm level (pigs). Faecal samples are collected annually in elite breeding herds, gilt-producing herds and twice annually in so-called sow pools. In addition to the Salmonella control programme, all weaner pig producing/integrated herds affiliated to a health control programme run by the industry, are tested by faecal samples collected annually. Annually approximately 8000 samples are collected and analysed.

- Testing for Salmonella of all sanitary slaughtered animals as well as any suspect animal at normal slaughter.

- Surveillance at all slaughterhouses: Sampling strategies are outlined in the Swedish Salmonella control programme approved by the EU. Sampling of slaughtered animals (cattle and pigs) are carried out in all abattoirs. Samples consist of intestinal lymph nodes and swabs taken from parts of the carcass where the chances of finding Salmonella is considered optimal. Annually approximately 20000 samples are collected and analysed.

- Epidemiological investigations are performed at suspicion/finding of Salmonella, for example trace back investigations from Salmonella infected herds, at findings of Salmonella at autopsy or investigations in connection to human cases of Salmonella. 
- General surveillance by clinical checks made by practising and animal health veterinarians. Samples for culture of Salmonella may also be performed at autopsies.

\section{$\underline{\text { Food }}$}

Any finding of Salmonella enterica, irrespective of subspecies, in food of animal origin is compulsory notifiable. Positive findings in any food item sampled within the official control or within own-check programs approved by the competent authority are also notifiable. Any food contaminated with Salmonella sp. is deemed unfit for human consumption and destroyed.

Municipalities (Local authorities) are responsible for control of food at local level. The extent of the sampling is decided by each local municipality. Special projects under the supervision of NFA may be instituted. During year 2000 a Campylobacter project is running, where the presence of Campylobacter in fresh meat and surface water reservoirs are investigated.

Sampling strategies at cutting plants are outlined in the Swedish Salmonella control programme approved by the EU. Frequency of sampling is correlated to the capacity of the establishment. Depending on the production capacity, sampling is performed daily, weekly, monthly or biannually. Samples consist of crushed meat, trimmings etc. Annually approximately 7000 samples are analysed.

\section{$\underline{\text { Human }}$}

Salmonella infection is notifiable under the Communicable Diseases Act. The surveillance is mainly based on passive case findings. In addition sampling of contact persons, both with and without clinically symptoms occur in connection with Salmonella cases/outbreaks. People with certain "risk professions" may be sampled after visits abroad.

\subsubsection{Others}

\section{Campylobacter}

Findings of Campylobacter is not notifiable in animals or in food. A surveillance system exists for broilers. It is an industry led programme whereby every flock sent for slaughter, is examined for Campylobacter at the slaughterhouse.

There is no officially co-ordinated surveillance system for Campylobacter in food. Surveillance is achieved by various projects initiated by municipalities, the NFA, the Institute for Meat Research and other research institutions.

Campylobacter infection in humans is notifiable under the Communicable Diseases Act. The surveillance is mainly based on passive case findings.

\section{VTE. coil 0157}

Any case of VT E. coli $\mathrm{O} 157$ in animals with connection to a human case of enterohaemorrhagic disease is compulsory notifiable. Since 1997, approximately 2000 faecal samples from cattle are collected annually at slaughter-houses and analysed for VT $E$. coli $\mathrm{O} 157$.

E. coli $\mathrm{O} 157$ in food : Since the $1^{\text {st }}$ January 1998,900 carcasses of cattle are sampled and analysed for E. coli $\mathrm{O} 157$ annually. On a voluntary basis, bacteriological examina- 
tion for VT E. coli $\mathrm{O} 157$ is performed on slaughtered cattle and sheep originating form infected herds. Local authorities are responsible for control of food at local level. The extent of the sampling is decided by each local municipality

In humans, enterohaemorrhagic E. coli $\mathrm{O} 157$ is a notifiable disease under the Communicable Diseases Act since 1996. Any case where E. coli O157 has been isolated, including subclinically infected people is reported. Other serotypes of verocytotoxic $E$. coli than $\mathrm{O} 157$ are reportable on a voluntary basis.

\subsubsection{Monitoring/Surveillance of Anti-microbial Resistance}

In Sweden, monitoring of resistance to anti-microbials in Salmonellae has been conducted since 1978. Surveillance of resistance in other animal bacteria has depended on point-prevalence studies of key pathogens carried out on an ad hoc basis. However, in 2000 a programme for monitoring of resistance in bacteria from animals (Swedish Veterinary Antibacterial Resistance Monitoring, SVARM) was been started at NVI.

The overall aim of the programme is to obtain data on antibacterial sensitivity of bacteria from animals and to detect trends in resistance. The results can be used as a basis for policy recommendations and for evaluation of the effect of interventions such as changed usage of anti-microbials. The scope of the programme is presented below. (table 6) 
Table 6. Overview of the SVARM programme.

\begin{tabular}{|c|c|c|c|}
\hline Bacteria to be tested & Source & \begin{tabular}{|c|}
$\begin{array}{c}\text { Number of isolates } \\
\text { per year }\end{array}$ \\
\end{tabular} & Sample collection \\
\hline \multicolumn{4}{|l|}{ Zoonotic bacteria } \\
\hline Salmonella spp & Mammals and birds & All available & Salmonella control programme \\
\hline $\begin{array}{l}\text { Campylobacter spp (jejuni and } \\
\text { coli) }\end{array}$ & Pigs, broilers, cattle & 100 per species & Sampling at slaughterhouses \\
\hline \multicolumn{4}{|l|}{ Animal pathogens } \\
\hline Staphylococcus aureus (mastitis) & Cattle & All available & Diagnostic submissions \\
\hline $\begin{array}{l}\text { Coagulase negative staph. (masti- } \\
\text { tis) }\end{array}$ & Cattle & All available & Diagnostic submissions \\
\hline E. coli (mastitis) & Cattle & All available & Diagnostic submissions \\
\hline $\begin{array}{l}\text { Streptococcus dysgalactie and } \\
\text { uberis }\end{array}$ & Cattle & All available & Diagnostic submissions \\
\hline Pasteurella sp. & Cattle & All available & Diagnostic submissions \\
\hline E. coli (enteritis) & Pigs & All available & Diagnostic submissions \\
\hline Actinobacillus pleuropneumoniae & Pigs & All available & Diagnostic submissions \\
\hline Pasteurella multocida & Pigs & All available & Diagnostic submissions \\
\hline Staphylococus intermedius & Dogs & All available & Diagnostic submissions \\
\hline Streptococcus zooepidemicus & Horses & All available & Diagnostic submissions \\
\hline Rhodococcus equi & Horses & All available & Diagnostic submissions \\
\hline \multicolumn{4}{|l|}{ Indicator bacteria } \\
\hline E coli & Pigs, broilers, cattle & 300 per species & Sampling at slaughterhouses \\
\hline Enterococcus spp. & Pigs, broilers, cattle & 300 per species & Sampling at slaughterhouses \\
\hline
\end{tabular}

\subsubsection{Risk Assessment Activities}

Historically, non-formalised risk assessments have been the basis for risk management initiatives to improve food safety. The use of formal, structured risk assessments as described in documents of CODEX and EU's Scientific Committee for Food have so far been limited. Work to develop and implement a formalised and quantitative approach for risk assessments have been initiated at the NFA. This work is, in part, carried out in cooperation with the Zoonosis centre, NVI. Other initiatives of NFA to organise its work with microbiological risk assessment include:

- the establishment of an external expert group for food hygiene and microbiology. The group consists of experts in medicine, epidemiology, food hygiene, veterinary medicine, parasitology, bacteriology, virology and microbial food ecology. Twice a year, meetings with the expert group are arranged during which the expert group is consulted in questions related to microbial risk assessment and especially hazard identification and hazard characterisation. 
- the establishment of an internal risk assessment group with representatives from the Food Control Divisions and the Divisions of Microbiology and Toxicology. This is a forum for exchange of information but the group can also take initiatives to new projects. Examples of the latter include a quantitative risk assessment of the risk of Staphylococcal enterotoxin poisoning from consumption of soft cheese produced from unpasteurized milk and a national survey of Campylobacter in meat (beef and pork), poultry, and drinking water.

\subsubsection{Strengths and Weaknesses of the Swedish System}

\subsubsection{Strengths:}

- Tradition to focus on the whole production chain (from feed to fork)

- Salmonella: A well functioning system for many years including that action is taken at any finding of Salmonella aiming at eliminating the infection/contamination.

- Tradition of co-operation with the industry

- Tradition of monitoring anti-microbial resistance

- An improved co-operation between authorities has been obtained since the establishment of the Zoonosis Council and the Zoonosis Centre.

- Good cooperation between Nordic countries

\subsubsection{Weaknesses:}

- Lack of centralised system for control of the foodstuffs principally depending on the self-government of municipalities.

- Limited resources at each administrative level for food control - especially for sampling and laboratory examinations. Currently there is no overall strategy for the flow of information concerning disease risk within the food chain.

- More work needs to be done in analyzing data from feed to fork, in risk assessment, risk management and establishment of food safety objectives.

- Limited sources (epidemiologists, risk analysts, statisticians) exist today to evaluate data and to answer questions like; "are available sources allocated optimally?"

- Risk analysis and risk management are not always separated.

- Lack of centralised control of handling of human zoonotic issues. SIIDC and County medical officers belong to different authorities. The county medical officers are independent, while under the supervision of the National Board of Health and Welfare

- No national priorities are established concerning the monitoring of food borne pathogens in the food chain. 


\section{Discussion/Final Remarks}

This report has presented an overview of the existing risk management systems for food borne zoonotic pathogens within each Nordic country.

Each Nordic country has listed various strengths and weaknesses of their respective systems at the end of each chapter. Some countries have the same authority throughout the farm to table chain, enabling an increased co-ordination of risk management activities.

As a common theme in all the Nordic countries, the major strength of their risk management systems is that the systems encompasses the whole farm to table continuum. This is in accordance with one of the recommendations presented in the Codex document "Proposed Draft Principles for the Conduct of Microbiological Risk Management" referred to in the introduction. The working group is of the opinion that the guidelines listed in the Codex document should be followed to the largest possible extent. The Nordic views were that principle one, two, four, seven, and nine were the most important and also the most strongly represented in the Nordic countries. Thus, the group agreed that protection of human health should be the primary consideration in risk management. Furthermore, it was stressed that risk management should include clear interactive communication with consumers and other interested parties in all aspects of the process, and that processes should be transparent and fully documented. This implies right of access to documents, press releases, and openness in the administration. Thus, background material for actions taken should always be available, including considerations and priorities. The group was of the opinion that the precautionary principle is important, and could apply to considerations concerning the principle of regionalisation.

However, in the Nordic countries, the risk management process could be more structured, so that every process and decision is listed and documented, and that operating procedures are worked out. The functional separation of risk management and risk assessment is very important, and could be further improved: especially when the same person or same institution works with both risk assessment and risk management, the full separation of the two processes is difficult. The people involved in risk analysis must be fully aware of their specific authorisations within distinctly separated tasks.

The risk management as a structured process and the insurance that any control measures implemented are optimal regarding feasibility, efficiency and are proportionate may pose difficulties if there is lack of knowledge concerning the effectiveness of the planned control measures.

It is very important to take into account the uncertainty of any risk estimate, to apply new data to the continuing process, and to review the process. This implies the importance of that the authorities comprehend the nature of probability distributions as opposed to exact figures.

To illustrate the discussion, the following example of the risk management of Campylobacter in Iceland applies: 
The protection of human health was the primary consideration. A working group was formed to ensure the interactive communication with consumers and other interested parties. However, the process itself was not very structured. The results were well published. However, there was a failure to cite scientific literature, which is considered a fault in connection to the transparency. Risk management and risk assessment were separated as the two fields were occupied by different persons. Quantitative risk assessment was not carried out. The precautionary approach was applied during the implementation of the intervention. Most of the other principles were followed. 


\section{Supplementary Literature}

Denmark

Aabo, S. and Andersen, J. K.: Quantitative risk assessment on liquid pasteurised eggs. A model prepared by the Danish participants. In: Reports on tasks for scientific co-operation. Report of experts participating in Task 2.3, Annex (SCOOP/MICR/2.3, European Comission, DGIII). June 1999.

Baggesen, D.L.; Aabo, S.: Status of Salmonella Typhimurium DT104 in Denmark. (In Danish). Plus Proces, 4, 1999, p. 18-22.

Danish Directorate for Fisheries: Annual Report 1998.

Danish Institute for Fisheries Research: Homepage: www.dfu.min.dk, December 3, 1999.

Danish Plant Directorate: Annual Report 1998.

Danish Veterinary and Food Administration: Plan submitted by Denmark describing arrangements for implementation of the Zoonosis Directive. Revision 4, Copenhagen, August 1997.

Danish Veterinary and Food Administration: Circular on microbiological examinations of foodstuffs. (In Danish: Cirkulcere om mikrobiologiske undersøgelser af levnedsmidler). Copenhagen, December 1997.

Danish Veterinary and Food Administration: Guidelines on the interpretation of the number of aerobes found in foodstuffs, produced or distributed at retail level. (In Danish: Vejledning om vurdering af det aerobe kimtal i fødevarer, som er fremstillet eller håndteret i detailleddet). Søborg, January 1998.

Danish Veterinary and Food Administration: Surveillance system for foodstuffs 1993 - 1997. Part V. Microbiological contaminations. (In Danish: Overvågningssystem for levnedsmidler 1993 - 1997. Del V: Mikrobiologiske forureninger). In press.

Danish Veterinary and Food Administration: Salmonella Typhimurium DT104, multiresistant - from farm to table. (In Danish: Salmonella Typhimurium DT104, multiresistent-fra jord til bord). Søborg, May 1998.

Danish Veterinary and Food Administration: Salmonella in Danish and imported poultry. (In Danish: Salmonella i dansk og importeret fjerkrcekød). Søborg, September 1998.

Danish Veterinary and Food Administration: Guidelines on Foodstuff Hygiene. (In Danish: Vejledning om levnedsmiddelhygiejne). Søborg, Oktober 1998.

Danish Veterinary and Food Administration, Division of Microbiological Safety: Risk profile for pathogenic species of Campylobacter in Denmark. Søborg, September 1998.

Danish Veterinary and Food Administration: Guidelines on own check. (In Danish: Egenkontrolvejledningen). Søborg, December 1998. 
Danish Veterinary and Food Administration: Annual Report 1998.

Danish Veterinary and Food Administration: Guidelines on the Management of Pathogenic Micro-organisms in Foodstuffs. (In Danish: Vejledning om vurdering af patogene mikroorganismer i fødevarer). Søborg, 1999.

Danish Veterinary Laboratory \& Danish Veterinary Institute for Virus Research: Annual Report 1998.

Ministry of Food, Agriculture and Fisheries: Food inspection from stable to table. Inspection of food and livestock centralized at 11 regional offices. (In Danish: Fødevarekontrol fra jord til bord. 11 regionale centre samler kontrollen med fødevarer og husdyr). Copenhagen, 1998.

Ministry of Food, Agriculture and Fisheries: Guidelines on the management of discoveries of Listeria monocytogenes in foodstuffs. (In Danish: Vejledning om vurdering af fund af Listeria monocytogenes $i$ fødevarer). Copenhagen, 1998.

Ministry of Food, Agriculture and Fisheries: Guidelines on the control of Salmonella Typhimurium DT104, multiresistant, in pork, beef and poultry imported from other EU countries or third countries. (In Danish: Vejledning om kontrol af svine-, okse- og fjerkrcekød, indført fra andre EU-lande eller tredielande, for Salmonella Typhimurium DT104, multiresistent). Copenhagen, July 201998.

Ministry of Food, Agriculture and Fisheries: Denmark: Top priority on Food Safety. (In Danish: Fødevaresikkerhed - Danmark som foregangsland). Copenhagen, 1998.

Ministry of Food, Agriculture and Fisheries: Governmental Food Policy Statement. (In Danish: Regeringens fødevarepolitiske redegørelse). Copenhagen, January 1998.

Ministry of Health (Board of Health) \& Ministry of Food, Agriculture and Fisheries (DVFA): Guidelines on the notification of outbreaks of food borne diseases. (In $D a$ nish: Vejledning om information ved udbrud af fødevarebårne sygdomme). Copenhagen, 1998.

Ministry of Food, Agriculture and Fisheries: Annual Report 1998 (Politics, Production and Consumption). (In Danish with English summary). Copenhagen, 1999.

Ministry of Food, Agriculture and Fisheries: Annual Report on Zoonoses in Denmark 1998. Copenhagen, 1999.

Ministry of Food, Agriculture and Fisheries: Presentation Pamphlet. Copenhagen, 1999.

Ministry of Food, Agriculture and Fisheries: Annual Report on Zoonoses in Denmark 1999. Copenhagen, 2000.

National Food Agency: Dietary Habits in Denmark, 1995. (In Danish: Danskernes Kostvaner 1995). Søborg, May 1996.

Statens Serum Institut: Annual Report 1998.

Statens Serum Institut: Homepage: www.ssi.dk, December $6^{\text {th }}, 1999$.

Statistics Denmark: Agricultural Statistics 1998. (In Danish: Landbrugsstatistik 1998). Copenhagen, 1999.

Statistics Denmark: External trade by commodities and countries 1996 and 1998. (In Danish: udenrigshandelen fordelt på varer og lande). Copenhagen, 1997 and 1999. 


\section{Finland}

Niemi, V.-M., Rahkio, M. \& Ruutu, P. The reorganisation of surveillance and reporting system of food and water borne outbreaks in Finland. $4^{\text {th }}$ World Congress Food borne infections and intoxication, 7-12.6.1998, Berlin, Germany

National Food Administration: Annual report 1998.

National Veterinary and Food Research Institute: Annual report 1998.

Joint report by Ministry of Agriculture and Forestry, National Veterinary and Food Research Institute, National Public Health Institute, Plant Production Inspection Centre and National Food Administration: Zoonoses in Finland in 1995-1997.

Ministry of Agriculture and Forestry and National Veterinary and Food Research Institute: Control of foodstuffs of animal origin in Finland. 1998.

Ministry of Agriculture and Forestry and National Veterinary and Food Research Institute: Bacterial Resistance to Anti-microbial Agents in Finland. FINRES 1999.

\section{Norway}

Annual report on zoonoses and zoonotic agents in Norway, 1999. Oslo, 2000. www.vetinst.no/zoonose.htm

Kapperud, G., Jenum, P.A., Stray-Pedersen, B., Melby, K.K., Eskild, A., Eng, J.: Risk factors for Toxoplasma gondii infection in pregnancy: Results of a prospective case-control study in Norway. American Journal of Epidemiology 144: 405 - 412, 1996.

Kapperud, G., Skjerbe, E., Bean, N.H., Ostroff, S.M., Lassen, J: Risk factors for sporadic Campylobacter infections: results of a case-control study in southeastern Norway. Journal of Clinical Microbiology 30: 3117 - 3121, 1992.

Kruse, H.: Survey of the occurrence of anti-microbial resistant bacteria in Norwegian meat and meat products. (In Norwegian: Kartlegging av forekomst av antibiotikaresistente bakterier $i$ norsk kjøtt og kjøttprodukter). National Veterinary Institute, Oslo, 1998.

Løvseth, A., Kruse, H.: Survey programme of imported foodstuffs, autumn 1997. (In Norwegian: Kartleggingsprogram - importerte noeringsmidler høste 1997). National Veterinary Institute, Oslo, 1997.

Ministry of Agriculture: Governmental announcement no. 40: Food quality and consumer safety. (In Norwegian: Matkvalitet og forbrugertrygghet). Oslo, 1996-1997.

National Centre for Veterinary Contract Research and Communication Services, Ltd: Anima: www.veso-anima.no. The National Institute of Public health: Homepage: www.folkehelsa.no

The National Veterinary Institute. Homepage: www.vetinst.no

NORM-Vet 1999. Usage of anti-microbial agents in animals and occurrence of antimicrobial resistance in bacteria from animals, feed, and food in Norway 1999. The Norwegian Zoonosis Centre. Oslo, 2000. Homepage: www.vetinst.no/zoonose.htm 
The Norwegian Agricultural Inspection Service: Homepage: www.landbrukstilsynet.no.

The Norwegian Animal Health Authority: Homepage: www.dyrehelsetilsynet.no

The Norwegian Crop Research Institute: Homepage: www.planteforsk.no.

The Norwegian Food Control Authority: Strategy Plan 1998 - 2001. (In Norwegian). Oslo, April 1999.

The Norwegian Food Control Authority: Does the food keep up? Result report 1995 1997. (In Norwegian: Holder maten mål?). Oslo, May 1999.

The Norwegian Food Control Authority: Company Plan 1999. (In Norwegian). Oslo, May 1999.

The Norwegian Food Control Authority: Homepage: www.snt.no January 122000.

The Norwegian Ministry of Agriculture: Homepage: www.odin.dep.no/ld

The Norwegian Ministry of Health and Social Affairs: Homepage: www.odin.dep.no

Norwegian Public Expositions (NOU): Report no. 10: Effective food safety. (In Norwegian: Effektiv matsikkerhet). Oslo 1996.

The Norwegian Zoonosis Centre. Homepage: www.vetinst.no/zoonose.htm

\section{Sweden}

Department of Epidemioloy, SIIDC: Annual reports of contagious diseases.

National Food Administration: Homepage: www.slv.se

National Veterinary Institute, Swedish Board of Agriculture, National Food administration: Swedish Salmonella Control Programmes for Live Animals, Eggs and Meat. January, 1995.

National Veterinary Institute: Swedish report to the Commission concerning trends and sources of zoonotic infections recorded in Sweden. Uppsala. Annual reports since 1994.

National Veterinary Institute: Homepage: www.sva.se

Swedish Board of Agriculture: Records of outbreaks of Salmonella.

Swedish Board of Agriculture: Homepage: www.sjv.se

\section{Other}

ALINORM 01/33, appendix III: Codex working principles for risk analysis (at step 3).

Codex Alimentarius Commission, July 2000: Proposed Draft Principles and Guidelines for the Conduct of Microbiological Risk Management, at step 3 (CX/FH 00/6). Joint FAO/WHO Foods Standard Programme. 
FAO, 1998: The Application of Risk Communication to Food Standards and Safety Matters. FAO Food and Nutrition Paper No 70, Rome, 1998. 


\section{BELGIUM \& LUXEMBOURG}

Jean de Lannoy

Avenue du Roi, 202, 1190 Brussels

Tel +32 (0)25385169 Fax+32 (0)25380841

jean.de.lannoy@euronet.be

\section{CANADA}

Renouf Publishing Company Ltd

5369 Canotek Road, Ottawa, Ontario K1J 9J3

Tel + 1 (613) $7452665 \mathrm{Fax}+1$ (613) 7457660

order.dept@renoufbooks.com

www.renoufbooks.com

\section{CHINA}

CNPIEC

Europe Division 16 Gongti East Road, P.O. Box 88, Beijing Tel +86105066 688-8 Fax +86105063101

\section{DENMARK}

Svensk-Norsk Bogimport A/S

Esplanaden 8 B, 1263 København $\mathrm{K}$

Tel +4533142666 Fax +4533143588

snb@bog.dk

www.snbog.dk

\section{ESTLAND}

Astro Raamatud AS

Pärnu mnt 142, 11317 Tallinn

Tel +372 6548485 Fax +372 6548475

book@astro.ee

\section{FAROE ISLANDS}

H.N. Jacobsens Bókahandil

Postboks 55, 110 Tórshavn

Tel +29831 1036 Fax +298317873

hnj-bokh@post.olivant.fo

\section{FINLAND}

Akademiska Bokhandeln

PB 128, Centralgatan 1, 00101 Helsingfors

Tel +358 912141

akatilaus@akateeminen.com

www.akateeminen.com

\section{FRANCE}

Librairie LAVOISIER

14, rue de Provigny, 94236 Cachan Cedex Tel +33 (1) $47406700 \mathrm{Fax}+33$ (1) 47406702 group@lavoisier.fr

www.lavoisier.fr

\section{GERMANY}

UNO-Verlag GmbH

Am Hofgarten 10, 53113 Bonn

Tel +49 (0)228949020 Fax +49 (0)2289490222

info@uno-verlag.de

www.uno-verlag.de

\section{HUNGARY}

Euro Info Service

PO Box 1039, 1245 Budapest

Tel +36 (1) $3292487 \mathrm{Fax}+36$ (1) 3492053

euroinfo@euroinfo.hu

\section{ICELAND}

Mál og Menning

Laugavegi 18, 101 Reykjavik

Tel +354 (9)5152500 Fax +354 (9)5152505

verslun@mm.is

\section{LATVIA}

Jana Rozes Gramàtnica

Kr. Barona iela 5, 1011 Riga

Tel +371 (0)2 284288 Fax +371 7370922

\section{LITHUANIA}

Penki Kontinentai

A. Stulginskio 5, 2001 Vilnius

Tel +370 (5) 2664540 Fax +370 (5) 2664565

books@5ci.lt

www.books.It

\section{NORWAY}

Akademika A/S

Postboks 84 Blindern, 0314 Oslo

Tel +4722853030 Fax +4722853080

bloken@sio.uio.no

www.akademika.no

\section{ROMANIA}

Euromedia s.r.l.

Str Dionisie Lupu nr 65, 70184 Bucuresti

Tel + $4016140664 \mathrm{Fax}+4013129646$

\section{SWEDEN}

Fritzes

Kundservice, 10647 Stockholm

Tel +46 (0)8 $6909190 \mathrm{Fax}+46$ (0)8 6909191

order.fritzes@nj.se

www.fritzes.se

\section{THE NETHERLANDS}

De Lindeboom Internationale Publicaties b.v.

M.A. de Ruyterstraat 20 A, NL-7482 BZ Haaksbergen

Tel +31 (0)53 5740004, Fax +31 (0)535729296

books@delindeboom.com

www.delindeboom.com

\section{UNITED KINGDOM}

The Stationery Office

P.O. Box 276, London SW8 5DT

Tel +44 8706005522 Fax +44 8706005533

customer.services@tso.co.uk

www.tso.co.uk/bookshop

USA

Bernan

4611-F Assembly Drive, Lanham MD 20706-4391

Tel +1 (301) 4597666 Fax +1 (301) 4590056

query@bernan.com

www.bernan.com

\section{ÅLAND}

Lisco bok- och pappershandel

Skarpansvägen 25, Box 8, 22101 Mariehamn

Tel +358 (0)1817177 Fax +358 (0)1819771 info@lisco.fi 